\title{
Coastal sandy spit deposits (Lower Burdigalian/Eggenburgian) in the Alpine-Carpathian Foredeep of Lower Austria
}

\author{
Slavomír NEHYBA ${ }^{1, *}$ and Reinhard ROETZEL ${ }^{2}$ \\ 1 Masaryk University, Department of Geological Sciences, Faculty of Science, Kotlářská 2, 61137 Brno, Czech Republic \\ 2 Geological Survey, Neulinggasse 38, 1030 Wien, Austria
}

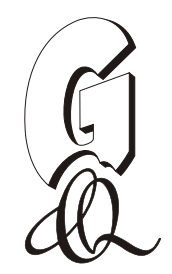

\begin{abstract}
Nehyba, S., Roetzel, R., 2021. Coastal sandy spit deposits (Lower Burdigalian/Eggenburgian) in the Alpine-Carpathian Foredeep of Lower Austria. Geological Quarterly, 65: 50, doi: 10.7306/gq.1619

In the type-area of the Eggenburgian regional stage (Lower Burdigalian) sands with large-scale clinoforms were studied north-west of Eggenburg (Lower Austria). Stratigraphic and facies architecture, palaeocurrent pattern and inferred palaeogeographic setting show that these sands are deposits of W-E trending and SW to SSE prograding coastal spit systems, attached to crystalline shoals or islets in the shallow marine Eggenburg Bay. The spits were dominantly formed by shoal parallel accretion above fair-weather wave base due to longshore transport. The $4-5 \mathrm{~m}$ thick clinoforms with bottomset, foreset and topset structures contain up to $3.6 \mathrm{~m}$ thick, steeply inclined foresets, dominated by sediment gravity-flow deposition. Relatively stable depositional conditions, characterized by strong unidirectional currents, high sand supply and sufficient accommodation space are assumed for their formation. However, internal reactivation surfaces indicate variations in current activity, orientation and velocity. The deposits of spit systems are interpreted as part of a transgressive systems tract. The provenance analysis reveals the local Moravian and Moldanubian crystalline rocks as principal source. The spit sands of the Burgschleinitz Formation show the highest mineralogical maturity within the studied Lower Miocene succession. Intense reworking and redeposition of material from older deposits is evident. Due to the ongoing transgression deposits of the following Gauderndorf Formation and Zogelsdorf Formation exhibit a larger catchment area with input of high amounts of fresh weathered material.
\end{abstract}

Key words: Alpine-Carpathian Foredeep, Early Miocene, Eggenburg Bay, coastal spit, provenance analysis.

\section{INTRODUCTION}

Prograding clastic clinoforms as a fundamental element of the basin infill have attracted an eminent attention in the sedimentological literature especially for their importance in petroleum industry and as an excellent palaeoenvironmental archive. They can provide valuable information about the tectono-stratigraphic evolution of the depositional system, including rates of progradation, aggradation and sediment flux (Patruno et al., 2015; Pellegrini et al., 2020). Although three major scales of clinoforms can be differentiated on the basis of vertical relief of the foresets (Pellegrini et al., 2020), their depositional environment is mostly connected with deltas (commonly Gilbert-type ones), linear shorelines or larger-scale shelf margins (e.g., Colella et al., 1987; Massari and Parea, 1990; Nemec, 1990; Hampson and Storms, 2003; Breda et al., 2007; Longhitano, 2008; Zecchin et al., 2010; Patruno et al., 2015). Generally smaller, both in areal extent and volumetrically, are coastal spits i.e. prograding shoreline accumulations, that frequently form in places of sudden change in mainland orientation

\footnotetext{
* Corresponding author, e-mail: slavek@sci.muni.cz
}

Received: August 10, 2021; accepted: October 9, 2021; first published online: November 3, 2021 where coastal deposits are reworked by waves and transported downdrift from local points of sediment discharge. Spits are also significantly less studied in the geological literature than other prograding sand bodies and are documented mostly from the Quaternary depositional record (Nielsen et al., 1988; Hiroki and Masuda, 2000; Mäkinen and Räsänen, 2003; Lindhorst et al., 2008; Nielsen and Johannessen, 2009; Zecchin et al., 2010; Dietrich et al., 2017; Fruergaard et al., 2018). Only few examples are known from older deposits (Rasmussen and Dybkjær, 2005; Leszczyński and Nemec, 2015).

Evidence of the coastal spit provide important and detailed insight into coastal morphology, nearshore processes and sediment supply. Coastal spits have in general various origins. They are commonly associated with retreating deltas or river mouths (Penland et al., 1988; Dietrich et al., 2017), the mouth of an estuary (Monge-Ganuzas et al., 2015), bedrock ridges or fault escarpments (Leszczyński and Nemec, 2015), prograding strandplains (Otvos, 2000; Tamura, 2012), related to topographic steps or abrupt change in orientation of shoreline (Zecchin et al., 2010). The evolution of a spit is the result of complex interactions between wave and tide dynamics (Hine,1979; Allard et al., 2008; Lindhorst et al., 2008; Nielsen and Johannessen, 2009; Dalrymple et al., 2012), fluctuations in sea level (Van Heteren and Van De Plassche, 1997; Fruergaard et al., 2015a), the impact of storms (Morton and Sallenger, 2003; Dougherty et al., 2004; Fruergaard et al., 2013), sediment supply (Fruergaard et al., 2015b, 2020; Oliver 
et al., 2017) and geological and morphological inheritance (Belknap and Kraft, 1985; Riggs et al., 1995). Because spits are very sensitive to all these factors and are formed quite rapidly (Nielsen and Johannessen, 2009), they serve as an instant and perceptive indicator of nearshore processes and palaeogeography. Moreover, understanding spit formation and evolution is increasingly important in order to assess how these soft-sediment coastal systems will respond and adapt to expected future changes in storm intensity and sea level (Fruergaard et al., 2020).

The presented paper describes a unique occurrence of Eggenburgian (Lower Burdigalian, Lower Miocene) deposits in the Alpine-Carpathian Foredeep, where several metre high clinoforms attached to the crystalline basement of the Bohemian Massif were studied in the broader surroundings of the village Maigen north-west of Eggenburg (Lower Austria). The sedimentary structures and depositional processes were integrated into a depositional model of these deposits and a well-understood palaeogeography based on detailed geological mapping enabled an insight into coastal processes. Provenance analysis of the outcropped Lower Miocene succession provides further data about the Eggenburgian transgression onto the southeastern margin of the Bohemian Massif.

\section{GEOLOGICAL SETTING}

The investigated area is located at the southeastern margin of the Bohemian Massif in northeastern Austria. It is made up from Precambrian crystalline basement rocks, which are covered by Lower Miocene (Lower Burdigalian/Eggenburgian to Ottnangian) sediments. Both are covered in parts by Pleistocene loess, loam and solifluction deposits (Figs. 1 and 2).

The crystalline basement in this area is mainly part of the Moravian Superunit. The crystalline rocks are Precambrian (Neoproterozoic) metamorphic rocks, like paragneiss, mica-schist, quartzite, marble and calc-silicate gneiss. They were intruded in the Late Neoproterozoic by different granites and granodiorites. In a late tectonic phase during the Variscan orogeny, they were transformed with increasing intensity towards the west to gneiss (Bittesch gneiss, Buttendorf gneiss, Therasburg gneiss, Eggenburg granite). In the study area, the different rock units are striking mainly $\mathrm{N}-\mathrm{S}$ to NNE-SSW and dipping west to north-west.

In the surroundings of Eggenburg crystalline ridges and inselberg-like hills protrude from Lower Miocene marine clastic deposits. It is a tectonically induced horst-and-graben topography, where marine sediments surround crystalline elevations and fill depressions between (Roštínský and Roetzel, 2005; Fig. 2). Due to strong exhumation in the Late Miocene and Pliocene, today's landscape roughly mirrors the palaeogeography of the Early Miocene Eggenburg Bay. Detailed geological mapping and facies analyses reconstructed a shallow marine bay with numerous crystalline islands, which was sheltered towards the open sea in the east by roughly $\mathrm{N}-\mathrm{S}$ trending crystalline elevations.

In the Lower Miocene sediment cover of the Eggenburg Bay two distinct transgressive successions with several lithostratigraphic units can be distinguished (Roetzel et al., 1999; Mandic and Steininger, 2003; Piller et al., 2007). The first marine transgression, starting in the early Eggenburgian, is reaching the Eggenburg Bay in the late Eggenburgian and follows directly above the crystalline basement.

Generally, the succession starts with the sedimentation of the shallow marine Burgschleinitz Formation, which consists of immature, moderately to poorly sorted, coarse- to fine- grained sands with gravelly intercalations. In most cases the sands are several metres thick, but do not exceed $10 \mathrm{~m}$. Locally, poorly sorted highly immature angular to subangular and partly gravelly silty and clayey sands, sandy silts and clays of the brackish Kühnring Member form the base above the crystalline basement and are laterally interfingering with the Burgschleinitz Formation. Deposits of the Kühnring Member mainly occur in basal positions in palaeovalleys and depressions, like west of Kühnring and Eggenburg as well as in the study area between Klein-Meiseldorf, Sigmundsherberg, Maigen and Engelsdorf. The Kühnring Member is characterized by oyster reefs of Crassostrea gryphoides together with Perna haidingeri beds and dense accumulations of Granulolabium, indicating fluctuating salinity in estuarine shallow subtidal to intertidal areas with fresh water inflow (Mandic and Steininger, 2003). Around Klein-Meiseldorf, the brackish sediments are westward passing over into gravelly and sandy deposits of the Rodingersdorf Formation from a fluvial-estuarine input from the north-west (Fig. 2).

In the Burgschleinitz Formation grain size, sorting as well as sedimentary structures, such as even lamination, low to high angle cross-stratification and current ripple cross lamination indicate a shallow marine, wave and storm dominated upper to lower shoreface environment (Roetzel, 1990; Pervesler et al., 2011). Shell layers and coarse-grained graded horizons, partly with remains of sea cows and other vertebrates, are interpreted as tempestites (Pervesler et al., 1995). At wave-dominated exposed positions at the outside of the Eggenburg Bay basal conglomerates with granitic boulders and cobbles frequently occur. Due to variegated environmental conditions inside the bay, like changing palaeorelief, water depth and palaeocurrents, lithofacies and biofacies of the Burgschleinitz Formation are both laterally and vertically generally very variable.

A fully marine, warm and shallow-water depositional environment is also supported by palaeoenvironmentally indicative bivalves, gastropods and trace fossils. The thick-shelled and large-sized mollusc-fauna is dominated by marine, littoral to shallow sublittoral species like Glycymeris fichteli, Isognomon rollei, Gigantopecten holgeri, Pecten pseudobeudanti, Ostrea lamellosa, Cordiopsis incrassata, C. schafferi, Paphia benoisti, Lutraria sanna and Allmonia paucicincta (Schaffer, 1910, 1912, 1914; Steininger, 1971; Mandic and Steininger, 2003). Furthermore, in some outcrops, like in the type locality of the Burgschleinitz Formation, a highly diverse nearshore trace fossil community occurs (Ehrenberg, 1938, 1944; Pervesler et al., 2011). Among these Ophiomorpha nodosa Lundgren is the most common type (Hohenegger and Pervesler, 1985). Additionally, remnants of vertebrates, like fish teeth (sharks, rays, breams) and bones of dolphins (Schizodelphis sulcatus), whales, crocodiles (Gavialosuchus eggenburgensis), turtles, sea cows (Metaxytherium krahuletzi) and the anthracothere Brachyodus onoideus are evidence for the diverse fauna in and around the Eggenburg Bay (Toula and Kail, 1885; Neumayr, 1888; Depéret, 1895; Abel, 1904; Schaffer, 1925; Brzobohatý and Schultz, 1971; Daxner-Höck, 1971; Steininger, 1971: 134 ff., 146 ff., 154 ff.; Pervesler et al., 1995; Domning and Pervesler, 2001).

The sediments of the Burgschleinitz Formation and the Kühnring Member are biostratigraphically dated by their small mammal fauna to the European land mammal Zone MN3 (basal Orleanian; Mein, 1989), which enables a direct correlation with the basal Burdigalian (Steininger et al., 1996; Steininger, 1999). Furthermore, Burdigalian, Mediterranean-type pectinid species such as Gigantopecten holgeri (Geinitz) and Flexopecten palmatus (Lamarck) place the Burgschleinitz Formation into the late Eggenburgian. 

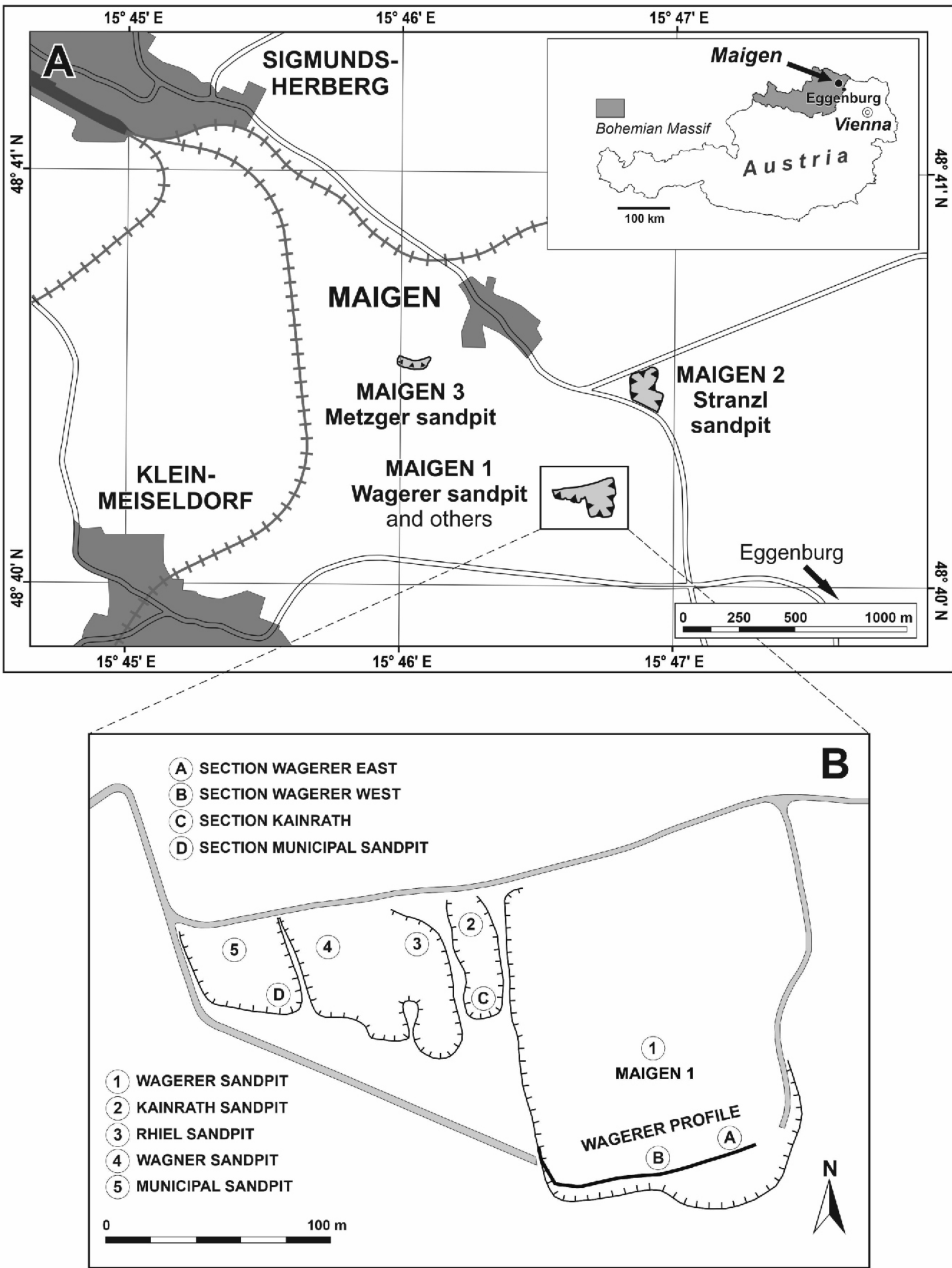

Fig. 1A - location of the investigated outcrops in the surroundings of Maigen village; B - outcrop situation in the area of the Wagerer sandpit (Maigen 1), with position of investigated sections 


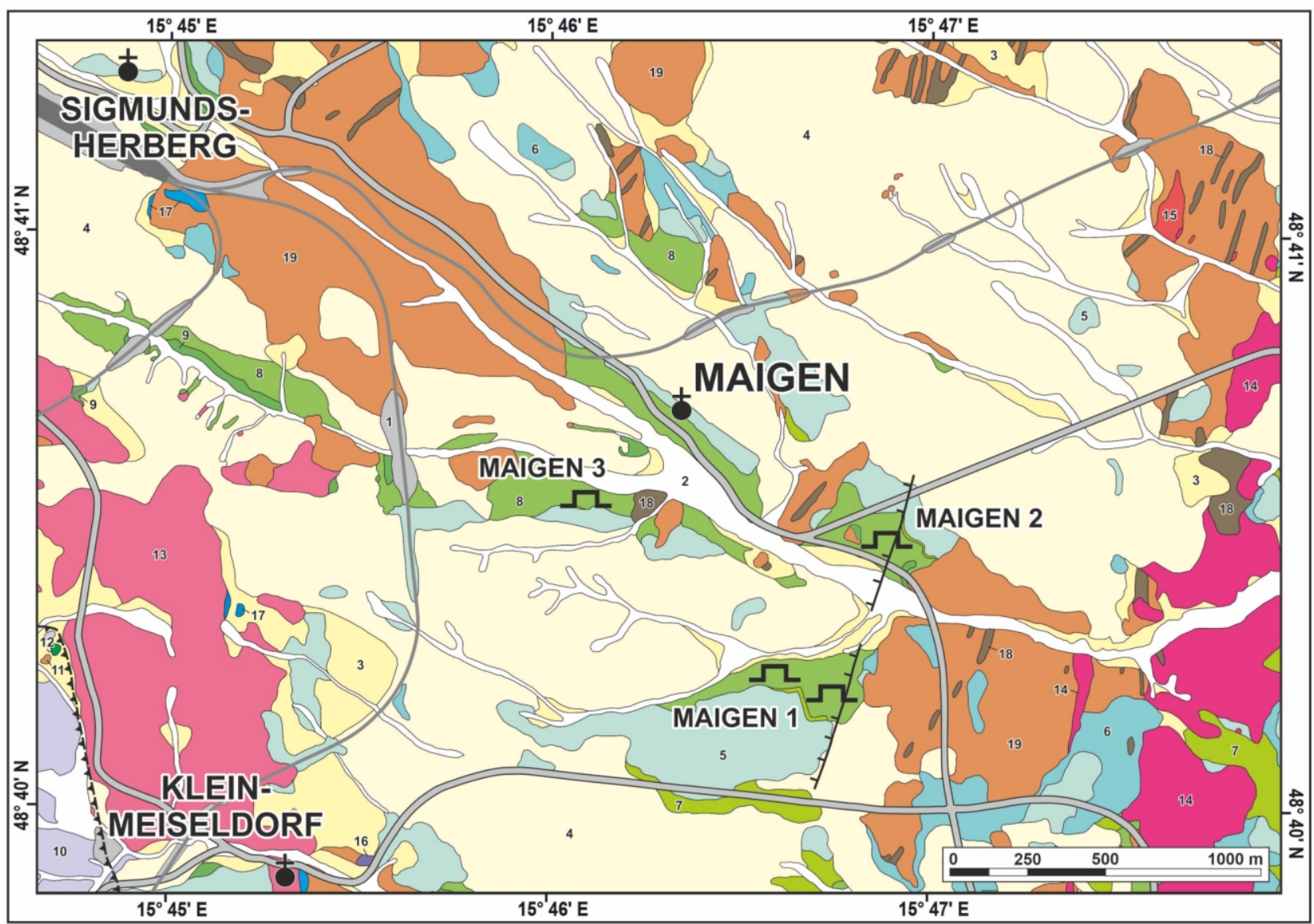

Pleistocene Sediments

\begin{tabular}{|l|l|}
\hline 1 & Anthropogene sediments \\
\hline 2 & Fluvial sediments \\
\hline 3 & Solifluidal sediments \\
\hline 4 \\
\hline
\end{tabular}

Alpine-Carpathian Foredeep

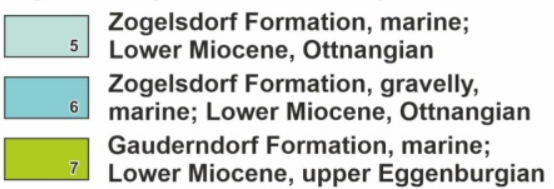

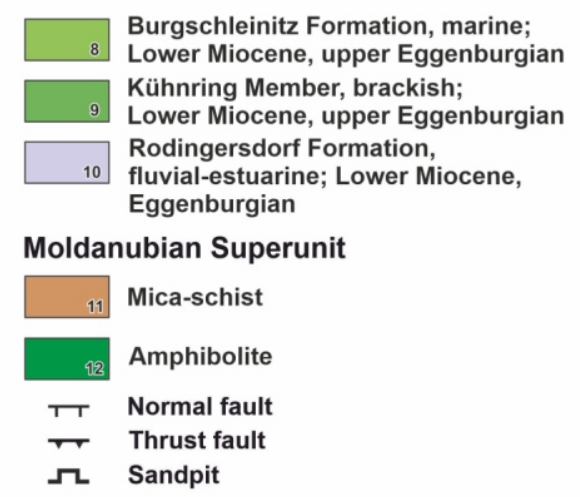

\section{Moravian Superunit}

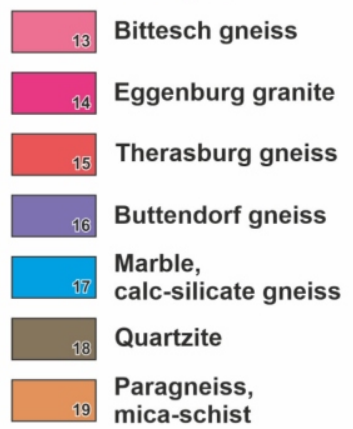

mica-schist

Fig. 2. Geological map of the surroundings of Maigen (mapped by R. Roetzel in 2005, 2006 and 2009)

In the central Eggenburg Bay, the superposing Gauderndorf Formation completes the first transgressive cycle, whereas in the northern and southern parts of the bay the Gauderndorf Formation is not developed. It consists of fine silty sands and silts, which often are following concordantly above the Burgschleinitz Formation or locally are laterally interfingering with them. However, in some areas a disconformity, marked by basal gravelly layers, is reflecting the deepening due to transgression. The diverse, thin-shelled, endobenthic and deep burrowing mollusc-fauna is totally contrasting the Burgschleinitz Formation. Infralittoral bivalves like Pharus legume, Solen marginatus and Angulus zonarius (Mandic and Steininger,
2003) dominate. Even to slightly undulating stratification of these fine silty sands is, in most cases, completely obliterated by the burrowing action of these molluscs. In contrast to the mollusc-fauna of the Burgschleinitz Formation this fauna is typical for sandy mud-bottoms below wave-base in slightly deeper, calmer and sheltered areas of the Eggenburg Bay (Roetzel et al., 1999; Mandic and Steininger, 2003).

The second transgressive cycle starts in the Eggenburg Bay with the Zogelsdorf Formation, which represents a renewed marine ingression into the bay (Nebelsick, 1989a, b). A distinct hiatus and a pronounced erosional relief, due to a sea level fall and regression around the Eggenburgian-Ottnangian 
boundary, mark the base of this formation. At the begin of the second transgression, parts of the Gauderndorf and Burgschleinitz Formation and their mollusc-fauna were locally reworked and redeposited in the basal parts of the Zogelsdorf Formation (designated by Suess, 1866 as "Molassesandstein" and Abel, 1898 as "Brunnstubensandstein"). The Zogelsdorf Formation, which is restricted to the Eggenburg Bay and their adjacent outer easterly margin, follows above the Burgschleinitz und Gauderndorf Formation as well as the crystalline basement. It is a fining and deepening upward succession, which consists of basal conglomerates, poorly sorted and silty coarse to medium-grained sands, sandstones, as well as coralline algae and bryozoan detrital limestones (Nebelsick $1989 a, b)$. In the western part of the Eggenburg Bay, close to higher basement elevations, gravelly sands and limestones mark the nearshore-facies of the Zogelsdorf Formation. Mollusc shells are always entirely diagenetically leached except for calcitic species (such as pectinids).

East of the Eggenburg Bay and the $\mathrm{N}-\mathrm{S}$ trending string of crystalline elevations, the Zogelsdorf Formation passes upsection into open marine clays and marls of the Ottnangian Zellerndorf Formation. Inside the bay, the Zellerndorf Formation is primary restricted to deeper depressions, showing laterally interfingering with the Zogelsdorf Formation. Generally, the Zogelsdorf Formation passes over into the Zellerndorf Formation by a metre-thick, poorly sorted and gravelly to coarse sandy silt to clay. Due to the rapidly progressing early Ottnangian transgression, also a direct onlap of the Zellerndorf Formation on crystalline elevations frequently occurs. The majority of the Zellerndorf Formation consist of fine laminated and thin-bedded, light and dark brown or bluish-grey, mostly non-calcareous and smectitic, very fine-grained silty clay. At the outer eastern rim of the Eggenburg Bay fine laminated, 5 to 7.5 -m-thick diatomite of the Limberg Member is intercalated and interfingering within the upper part of the Zellerndorf Formation. It is laterally thinning out towards the east and show upwelling-conditions along the crystalline scarp of the Bohemian Massif (Roetzel et al., 2006; Grunert et al., 2010).

\section{METHODS}

The main geological and sedimentological fieldworks were done in the 1970th to 1990th, many of them during field courses, excavations and trenching of the Institute of Palaeontology of the Vienna University (Fritz F. Steininger, Peter Pervesler, Reinhard Roetzel). In preparation for this paper both authors recently did additional fieldwork, although the outcrops are meanwhile in poor condition and partly heavily overgrown.

Fieldworks were based on detailed logging, drawing of bedding architecture in outcrops and photomosaics and measuring of palaeocurrent indicators (see Collinson et al., 2006). Primary sedimentary structures and textures were used for distinguishing the lithofacies (Walker and James, 1992). Lithofacies were grouped into facies associations (FA), i.e. assemblages of spatially and genetically related facies, that are the expressions of different sedimentary environments.

Grain size analyses were carried out from 75 samples by a combination of wet sieving in $1 / 2 \Phi$ intervals for fractions $>0.063 \mathrm{~mm}$. The finer fractions down to $2 \mu \mathrm{m}$ were analysed by a Micromeritics SediGraph 5000 ET. The grain size parameters were calculated as standardised moments with the program SedPakWin (Reitner et al., 2005). The average (avg) grain size is expressed by the first standardised moment (Mz), the uniformity of the grain size distribution/sorting by the second stand- ardised moment (graphic standard deviation $\sigma_{\mathrm{I}}$ ) and the degree of the symmetry by the moment coefficient of skewness.

Evaluation of both light and heavy minerals were used for provenance analyses. Light minerals of the fraction $0.063-0.425 \mathrm{~mm}$ from 40 samples were imbedded in synthetic resin and after curing and preparation of thin sections evaluated under the polarizing microscope. Heavy minerals from 42 samples were separated with tetrabromethan and after preparation in strew slides also quantified in the grain size fraction $0.063-0.425 \mathrm{~mm}$ under the polarizing microscope by the counting method. The opaque and translucent minerals were considered separately in the calculations.

\section{OUTCROP DESCRIPTIONS}

The sedimentary succession of the Lower Miocene deposits was open in several sandpits in the surroundings of the village Maigen (Fig. 1A).

The biggest was the Stranzl sandpit (Maigen 2), 800 m SE of Maigen, on the road to Eggenburg (N48 40'25", E15 $\left.46^{\prime} 52^{\prime \prime}\right)$. Lithology and lithostratigraphy of this sandpit were already depicted by Steininger $(1977,1983)$ and Steininger et al. (1991a, b). On the opposite side of a creek (Maigner Bach), $\sim 500$ m south of the Stranzl sandpit, five sandpits were open next to each other (Fig. 1A, B). The biggest was the Wagerer sandpit (Maigen 1, N48 $\left.40^{\prime} 11^{\prime \prime}, \mathrm{E} 15^{\circ} 46^{\prime} 40^{\prime \prime}\right)$. West of them four smaller sandpits (Kainrath sandpit: N48 40'11', E15 46'36", Rhiel sandpit: N48 $40^{\prime} 10,6^{\prime \prime}, \mathrm{E} 15^{\circ} 46^{\prime} 35,1^{\prime \prime}$, Wagner sandpit: N48 $40^{\prime} 10,7^{\prime \prime}, E 15^{\circ} 46^{\prime} 33,9^{\prime \prime}$, municipal sandpit, now landfill site; N48 40'11,1', E15 $46^{\prime} 31,8^{\prime \prime}$ ) were active (Fig. 1B). A further small sandpit (Metzger sandpit, Maigen 3) was open at the fields $\sim 450 \mathrm{~m}$ south-west of Maigen (N48 40'30,0", E15²6'00,1', Fig. 1A).

\section{CRYSTALLINE BASEMENT}

In the Wagerer and Stranzl sandpits the crystalline basement consisting of strongly weathered mica-schist was opened by trenching $4 \mathrm{~m}$, respectively $5 \mathrm{~m}$ below the mining level. In the Metzger sandpit mica-schists temporarily cropped out at the base. In the Stranzl sandpit the crystalline basement was exposed in the trench in the central part at $\sim 366 \mathrm{~m}$ a.s.. ., rising and cropping out towards west ( $378 \mathrm{~m}$ a.s. I.) and east (368 $\mathrm{m}$ a.s.I.). In the depression in the central part of the sandpit a NNE-striking reverse fault (300/62) caused a vertical slip amount of several metres of the hanging wall in the west (Fig. 2). Due to the presedimentary basement relief and further syn- and postsedimentary faulting, the formation-thickness is here quite variable, varying between $\sim 5 \mathrm{~m}$ in the west and $18 \mathrm{~m}$ in the eastern part (Fig. 3).

\section{KÜHNRING MEMBER}

Above the erosive crystalline surface in a first stage very coarse debris of angular mica-schist and rounded quartz in immature, very poorly sorted silty to sandy and gravelly matrix was deposited. These sediments of the Kühnring Member are fossiliferous, containing mainly debris of molluscs like Ostrea, Perna, Glycymeris, Turritella, Granulolabium, Paroxystele, Cordiopsis and Cerastoderma, besides reworked solitary corals and in some cases indeterminable bone-fragments of vertebrates (Fig. $4 \mathrm{H}$ ). In the Stranzl sandpit chronostratigraphically significant small mammals (Mein, 1989) and a species-rich otolith fauna (Brzobohatý, 1989) were found in these layers. 
MAIGEN 2 STRANZL SANDPIT

number of

facies association

\begin{tabular}{|c|c|}
\hline FA 7 & FA 6 \\
\hline FA 3 & FA 2 \\
\hline
\end{tabular}

SECTION

STRANZL WEST

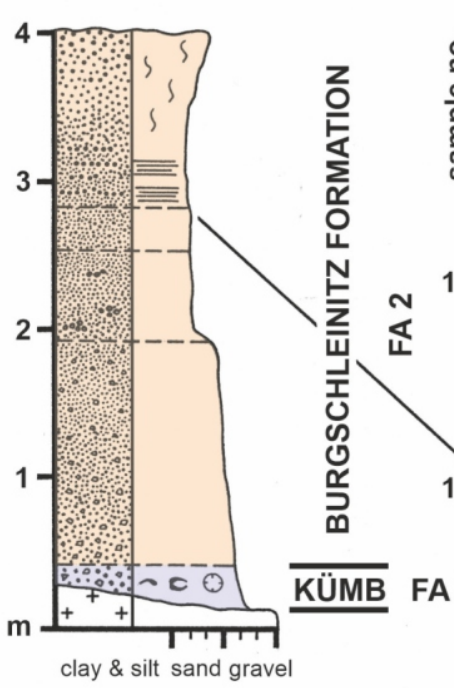

LITHOLOGY

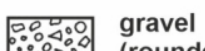

(rounded/angular)

coarse sand

medium sand

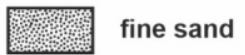

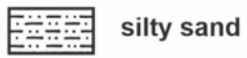

$\bigcirc \bigcirc$ concretions

$\oplus \oplus$ crystalline boulders

$+_{++}^{+}$crystalline basement

SEDIMENTARY STRUCTURES

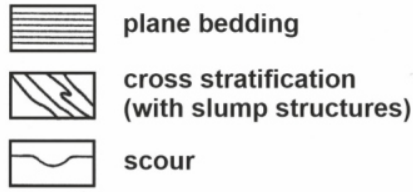

FOSSILS

- 0 bivalves

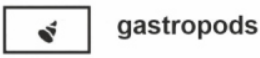

$\prec \succ$ bryozoans

$\theta$ corals

* coralline algae

vertebrate remains

S S trace fossils

STRANZL

TRENCHED SECTION

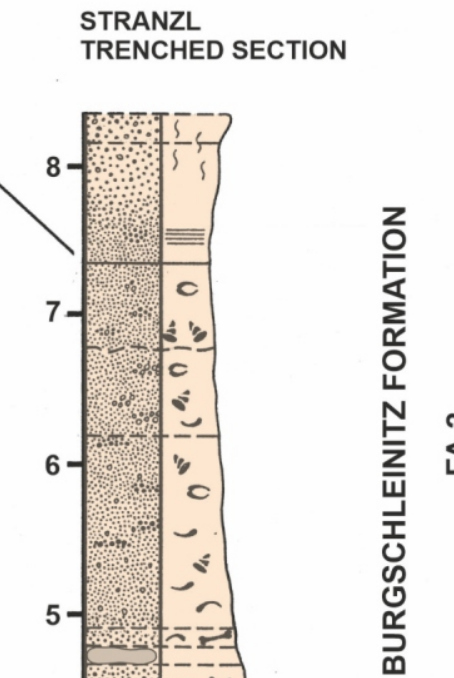

26

ㄴ. 25

23

24
22

20
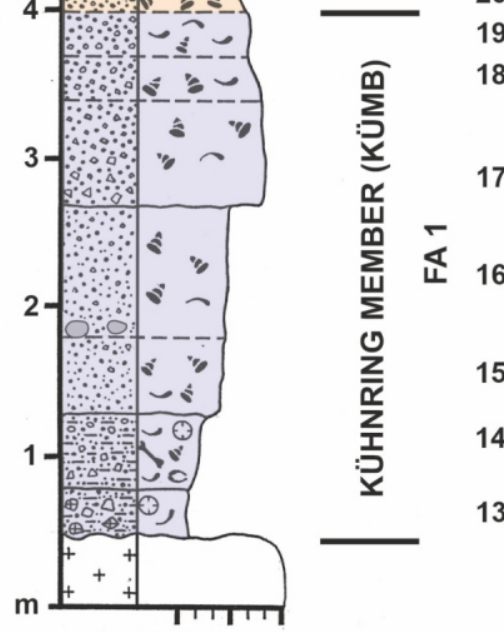

clay \& silt sand grave

13
SECTION

STRANZL EAST
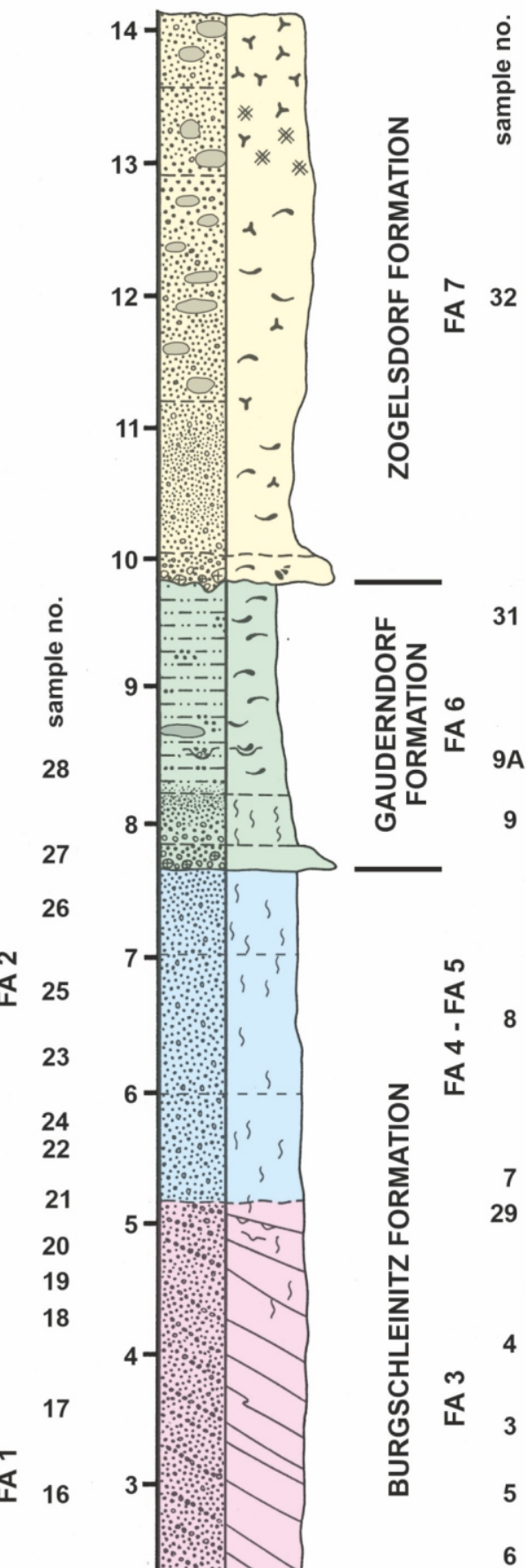

$\mathbb{1} 2$

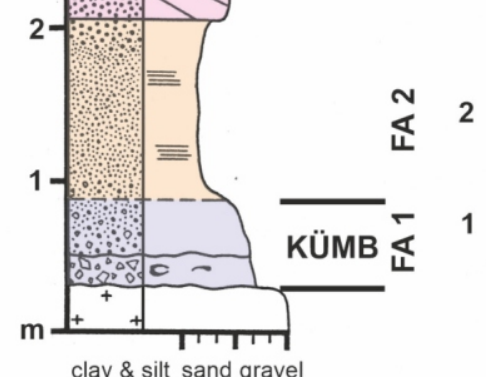

Fig. 3. Schematic lithostratigraphic logs of the Stranzl sandpit (Maigen 2; cf. Figs. 1 and 2) with distribution of facies associations (FA) and samples 

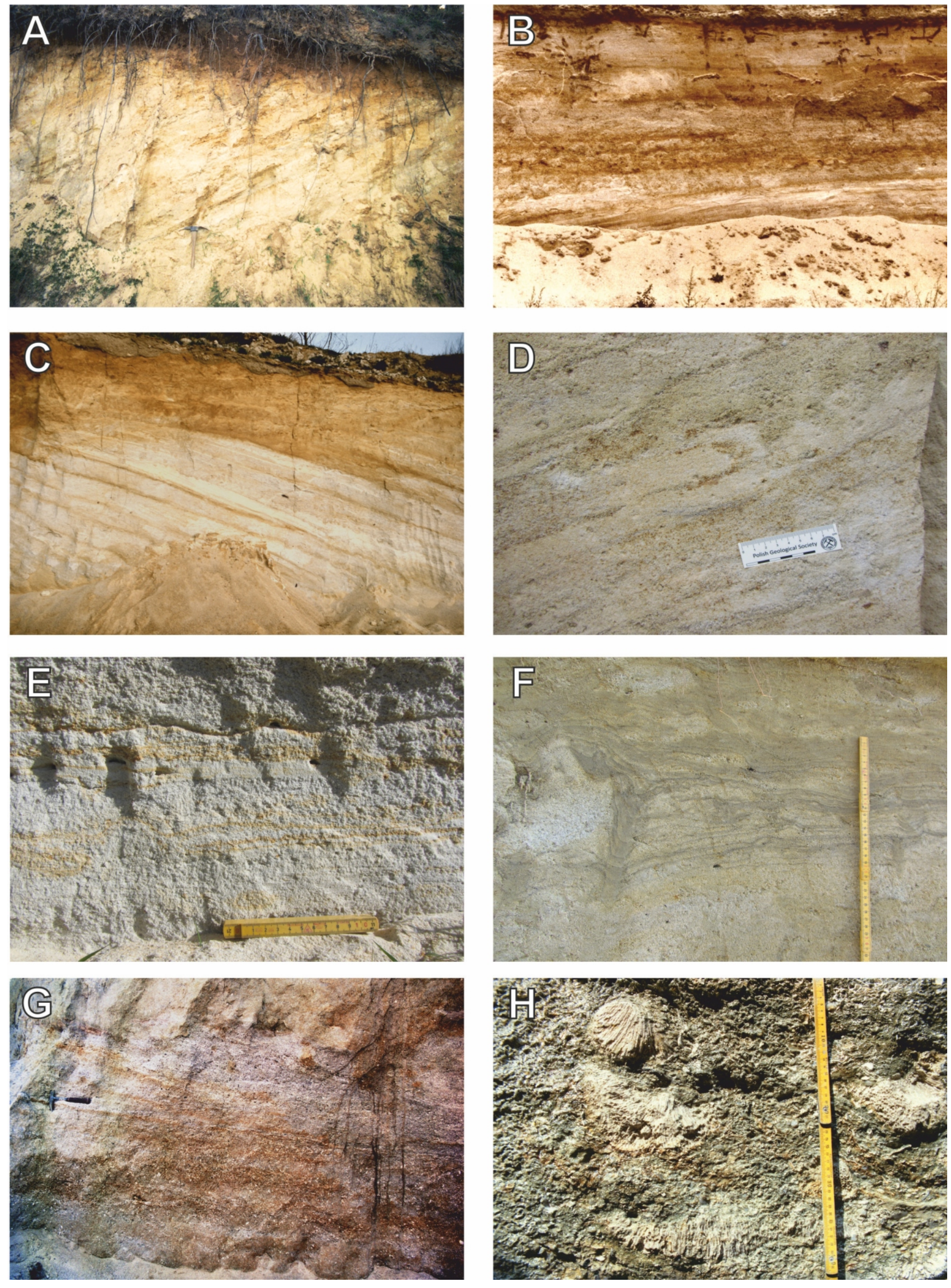

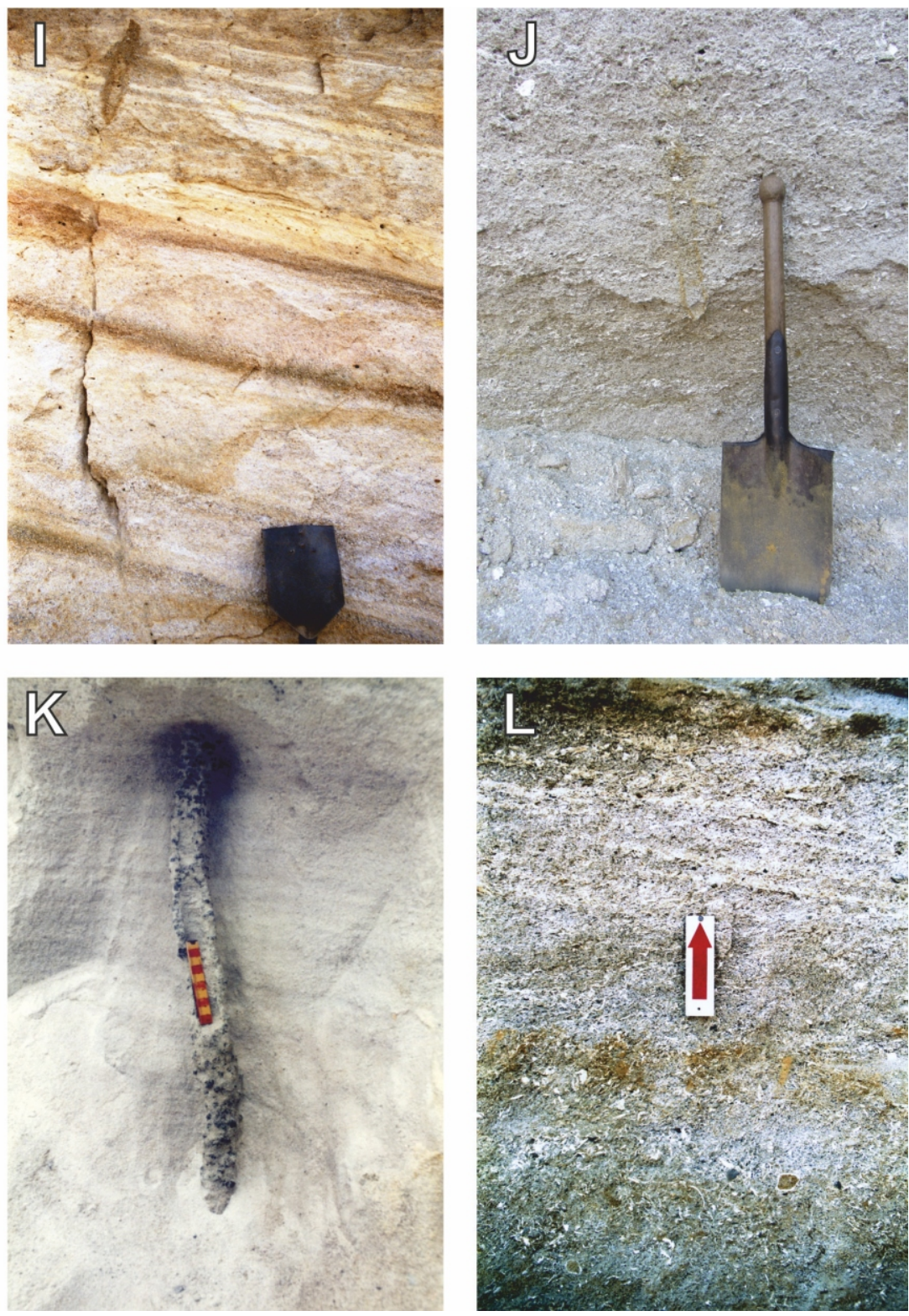

Fig. 4. Photos of lithofacies and facies associations (FA) within the logged sections

A - high angle cross-stratified sands of lithofacies SII in FA 3, Metzger sandpit (Maigen 3); B - coarse-grained sands with burrowing of Ophiomorpha nodosa (lithofacies SIb, FA 5) above subhorizontal beds of cross-stratified sands of FA 4, image height $\sim 2.5 \mathrm{~m}$, Stranzl sandpit (Maigen 2); C - top of high angle cross-stratified sands (lithofacies SII, FA 3) covered by bioturbated sands of FA 4, Stranzl sandpit (Maigen 2), image height $\sim 4 \mathrm{~m} ; \mathbf{D}$ - bioturbated high angle cross-stratified sands of lithofacies SII in FA 3, Metzger sandpit (Maigen 3); $\mathbf{E}-$ horizontal beds of lithofacies SI, Sw and SIb in FA 5, Stranzl sandpit (Maigen 2); F - bioturbated silty sands of lithofacies Fs in the Gauderndorf Formation (FA 6), Stranzl sandpit (Maigen 2); G - coarse low angle cross-stratified sands with drapes of shell-hash on foreset-beds (FA 3), at the top fine silty sands of the Gauderndorf Formation (FA 6), municipal sandpit Maigen; $\mathbf{H}$ - poorly sorted gravelly silty and clayey sands of lithofacies Sgm in the Kühnring Member (FA 1) with reworked solitaire corals and bone-fragments, Stranzl sandpit (Maigen 2, trenched section, sample 14); I - well-developed planar cross-stratification with alternation of slightly finer and coarser grained intervals (lithofacies SII, FA 3, foreset), Ophiomorpha top left, Stranzl sandpit (Maigen 2); J - calcareous sands of lithofacies Ls in FA 7 of the Zogelsdorf Formation, Wagerer sandpit (Maigen 1); $\mathbf{K}$ - about $7 \mathrm{~cm}$ thick pellet-walled burrow of Ophiomorpha nodosa in FA 4, Metzger sandpit (Maigen 3); $\mathbf{L}-$ shell-hash on low angle cross-stratified foresets in FA 3, note partly developed reverse oriented cross-stratification marked by shell-hash above the arrow, municipal sandpit Maigen, length of the arrow $10 \mathrm{~cm}$ 


\section{MAIGEN 1}

(D) SECTION MUNICIPAL SANDPIT
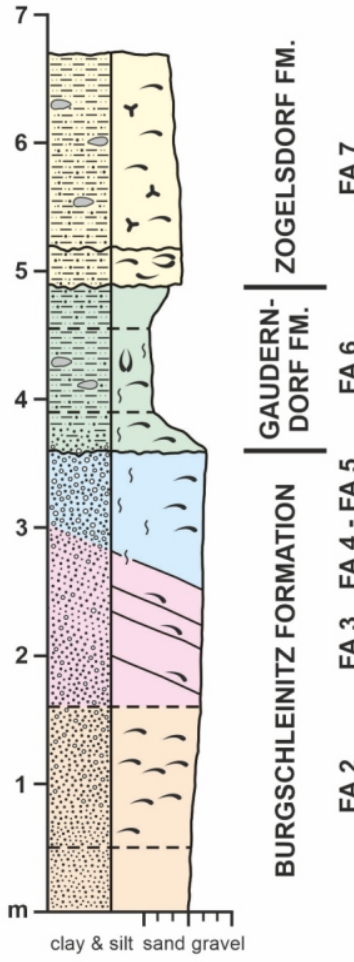

LITHOLOGY

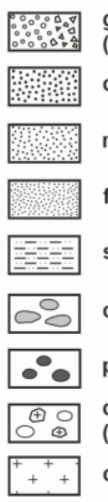

gravel

(rounded / angular)

coarse sand

medium sand

fine sand

silty sand

concretions

pelitic intraclasts

crystalline boulders

(rounded / angular)

crystalline basement
C SECTION KAINRATH
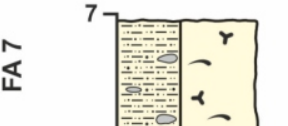

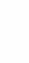

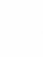
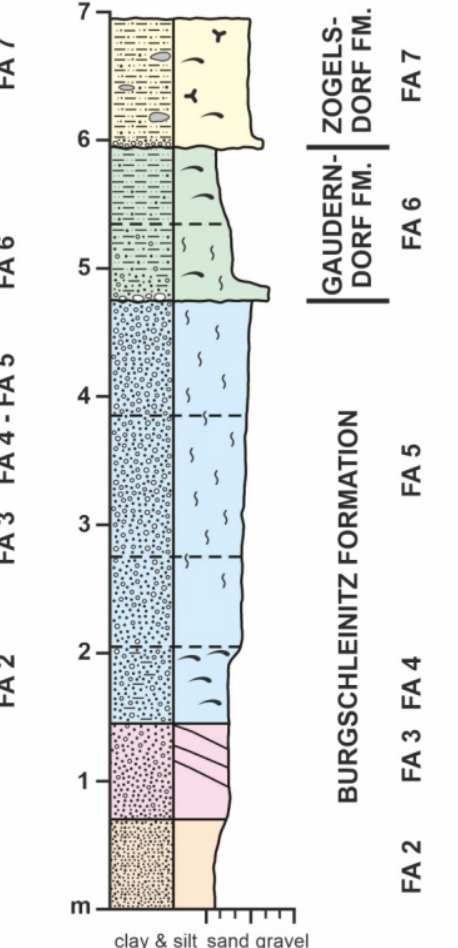

SEDIMENTARY STRUCTURES

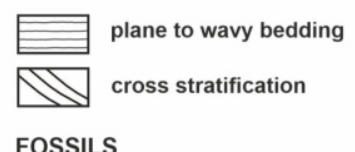

FOSSILS

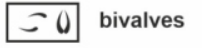

$\checkmark$ gastropods

$r^{r} r$ bryozoans

$\Theta$ corals

vertebrate remains

5,5 trace fossils

\section{(B) SECTION WAGERER}
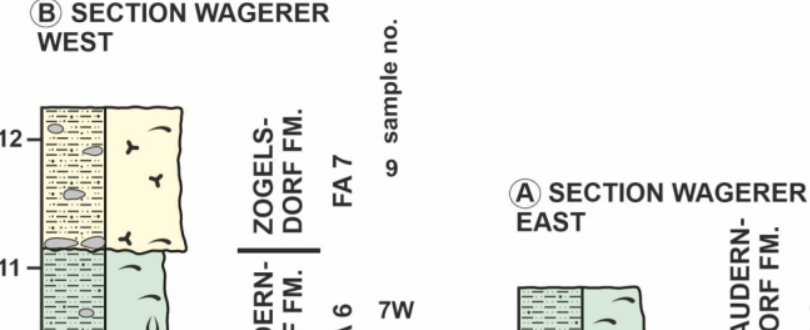

岁岩芯

$7 \mathrm{~W}$

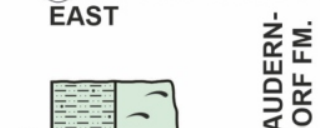

窟㐫

ำ

菦

近 $5 \mathrm{E}$

乐

$5 \mathrm{~W}$

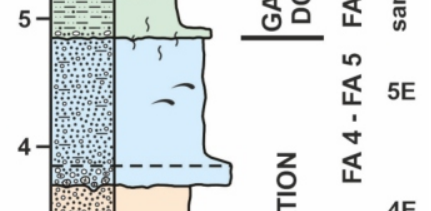

$4 W$

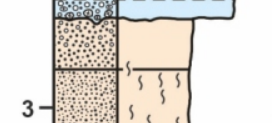

$4 \mathrm{E}$

$3 \mathrm{E}$

$\stackrel{4}{4}$

$2 \mathrm{E}$

$1 E$

10

number of

facies association

\begin{tabular}{|l|l|}
\hline FA 7 & FA 6 \\
\hline
\end{tabular}

FA 4/5 FA 3

\begin{tabular}{|l|l|}
\hline FA 2 & FA 1 \\
\hline
\end{tabular}

Fig. 5. Schematic lithostratigraphic logs of the Wagerer sandpit (Maigen 1; section A Wagerer east and B Wagerer west) and adjacent outcrops (section C Kainrath sandpit, section D municipal sandpit; cf. Figs. 1 and 2) with distribution of facies associations (FA) and samples

The Kühnring Member is filling erosive depressions, shown by a strongly varying thickness between several decimetre and up to 3.5 m (Fig. 5: section B, samples 11-14, Fig. 3: trenched section, samples 13-19; section Stranzl east, sample 1, Fig. 6: section Metzger west, samples 1-3).

\section{BURGSCHLEINITZ FORMATION}

The fining upward of the basal Kühnring Member continues in the Burgschleinitz Formation above. In the trench of the Wagerer sandpit the basal $2.5 \mathrm{~m}$ thick sequence consists of siltsands and silty fine- to medium-grained sands (Fig. 5: section B, samples 15-19) which have decimetre-thick fossiliferous layers, mainly from Granulolabium, in alternation with up to $30 \mathrm{~cm}$ thick horizons of Ostrea and Perna. The fossiliferous lower part is completed by $\sim 0.5 \mathrm{~m}$ clayey and silty fine- to medium-grained sands (Fig. 5: section B, sample 20, 21 and section $A$, sample 10) which are already characterized by a more diverse and fully marine mollusc-fauna (predominantly Acanthocardia moeschanum, Anadara fichteli grandis, Bucardium grande, Perna haidingeri, Cordiopsis gauderndorfensis, C. gigas, Macrocallista lilacinoides, Peronaea planata, Euthrio- 


\section{MAIGEN 3}

METZGER SANDPIT

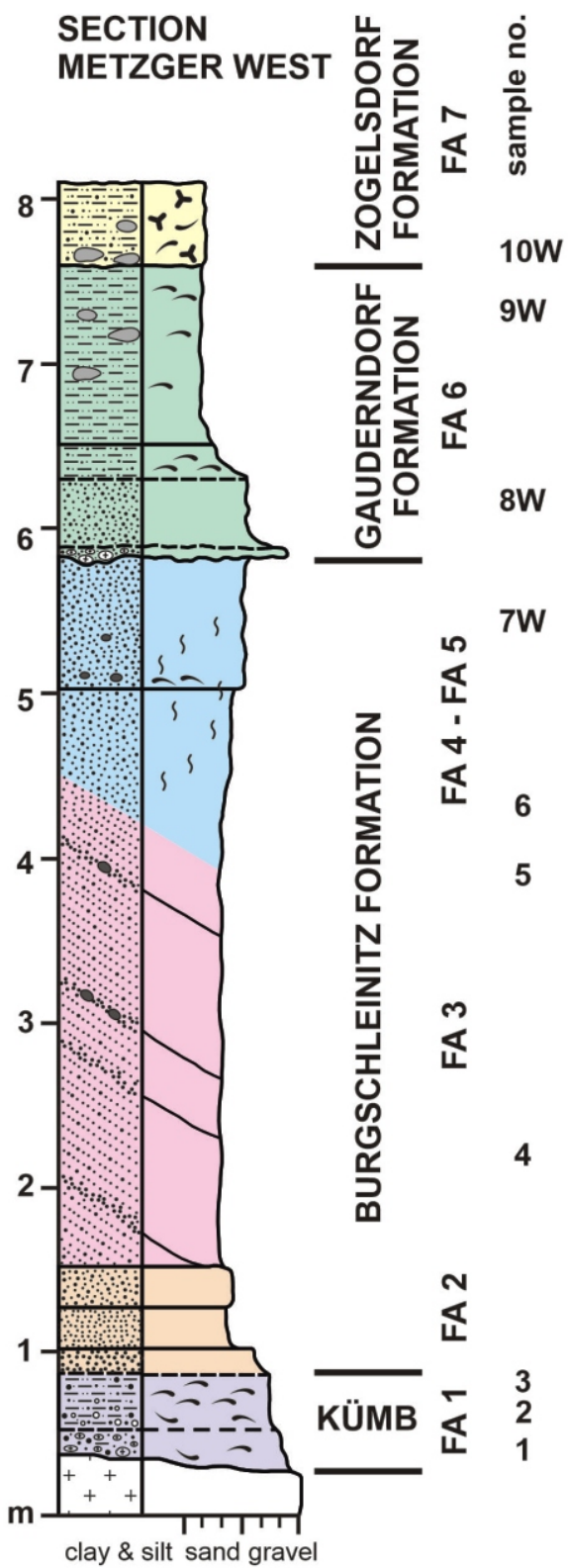

number of

facies association
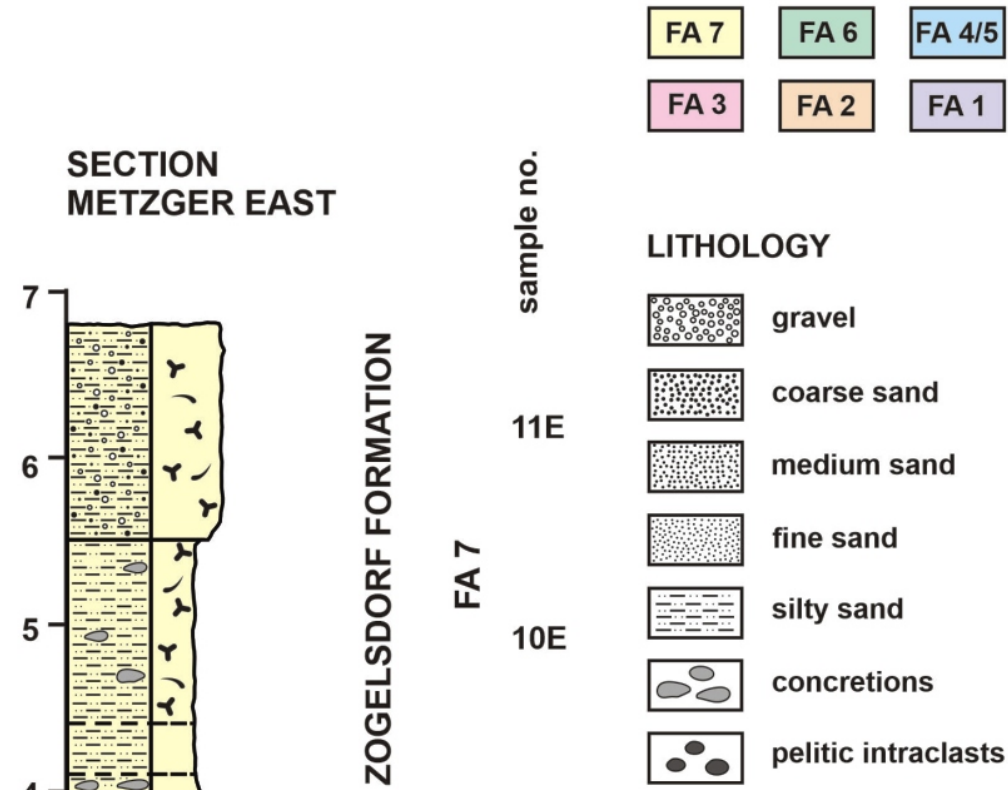

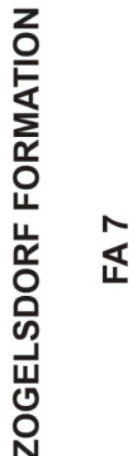

LITHOLOGY

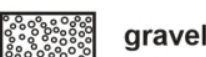

$11 \mathrm{E}$

coarse sand

medium sand

$10 \mathrm{E}$

fine sand

silty sand

08 concretions

- pelitic intraclasts

$\oplus^{\oplus} \oplus$ crystalline boulders

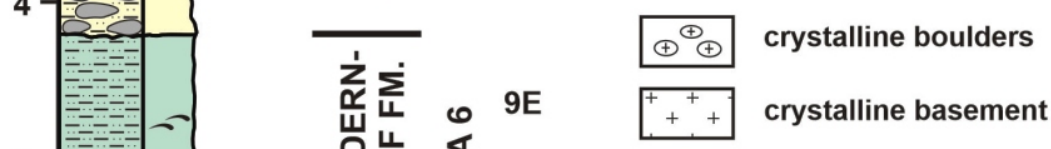

SEDIMENTARY STRUCTURES

$8 \mathrm{E}$

plane to wavy bedding

7E

cross stratification

FOSSILS

- b bivalves

$r^{\gamma} r$ bryozoans

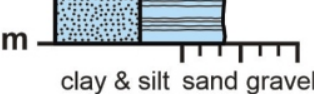

s, s trace fossils

Fig. 6. Schematic lithostratigraphic logs of the Metzger sandpit (Maigen 3; cf. Figs. 1 and 2) with distribution of facies associations (FA) and samples

fusus burdigalensis, "Natica” tigrina, Tudicla rusticula, Turritella inaequicingulata; Schauer and Schattleitner, 1982).

The trenched section in the Stranzl sandpit showed in the lower part $3.4 \mathrm{~m}$ coarser sediments from fine gravelly and silty fine- to coarse-grained sands with layers and lenses of well-rounded coarse sand and fine gravel (Fig. 3: trenched section, samples 20-27). In the abundant marine mollusc-fauna Peronaea and Turritella dominate, besides Granulolabium, Cerastoderma, Natica, Cordiopsis and Paroxystele. Additionally, in a layer with Perna and Ostrea a sea turtle-shell was found. Like in the Kühnring Member also small mammals (Mein, 1989) and otoliths (Brzobohatý, 1989) occurred in these sediments.
Above this fossiliferous basal part of the Burgschleinitz Formation starts a new sandy and coarsening upward cycle which is poor in fossils and only in parts bioturbated. The thickness of this section is greatest in the Wagerer outcrop and the adjacent sandpits 0.7-3.4 m (Fig. 5: section A, samples 1E-4E: 3.2 m; section $B$, samples $22-4 \mathrm{~W}: 3.4 \mathrm{~m}$; section C: $0.7 \mathrm{~m}$; section $\mathrm{D}$ : $1.6 \mathrm{~m}$ ). In the sections of the Stranzl and the Metzger sandpits is the thickness of these sediments significantly smaller due to a higher position of the crystalline basement. In these two outcrops they are maximally $1.3 \mathrm{~m}$ thick and consist of silty fine- to medium-grained and partly thin laminated sands (Fig.3: section Stranzl east, sample 2; Fig. 6: FA 2; Fig. 7: FA 2; Fig. 8: FA 2). 


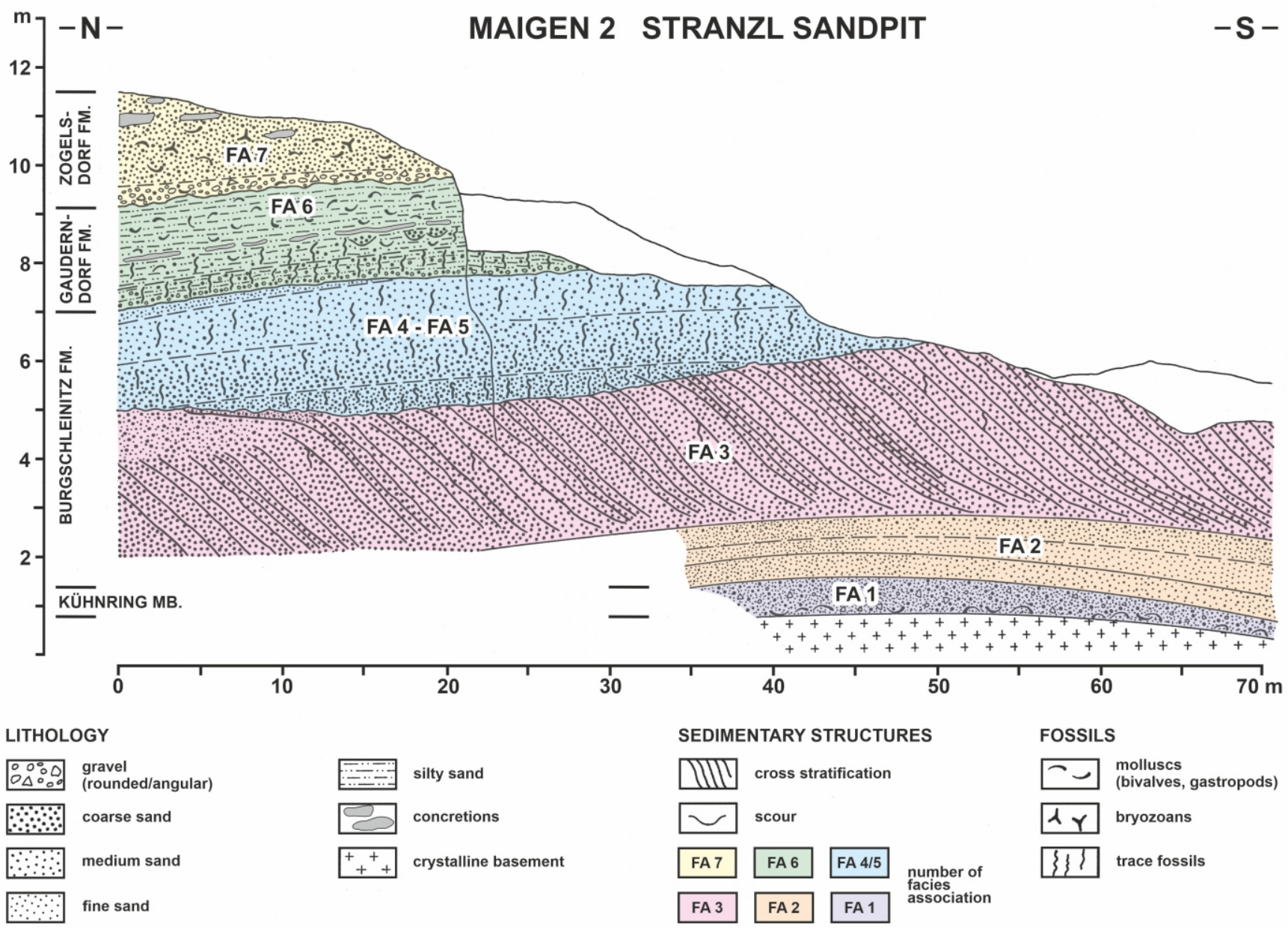

Fig. 7. Line drawing documenting the facies architecture (FA) and body geometries in the Stranzl sandpit (Maigen 2; situation 1985)

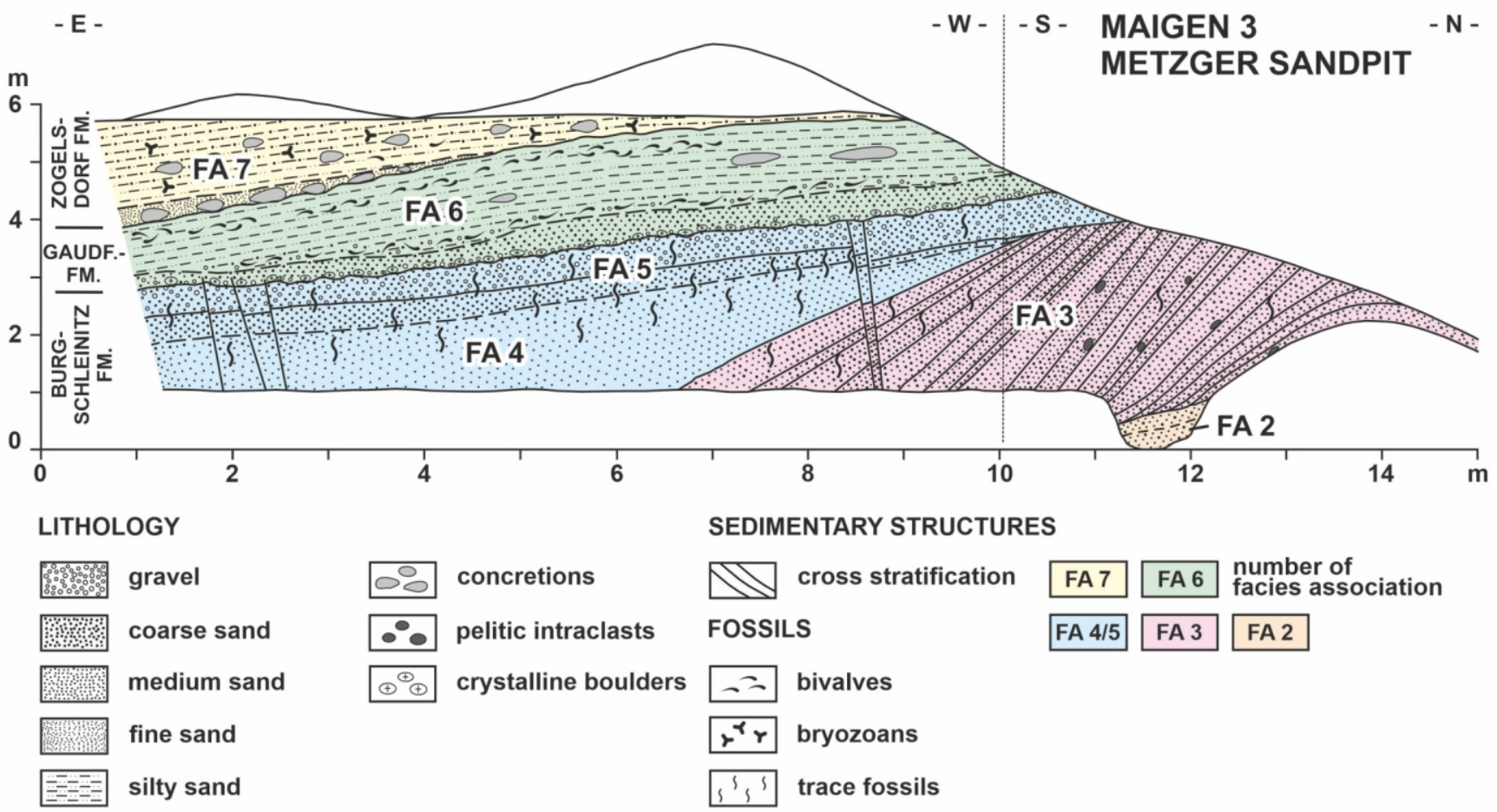

Fig. 8. Line drawing documenting the facies architecture (FA) and body geometries in the outcrop in the Metzger sandpit (Maigen 3; situation 1985) 


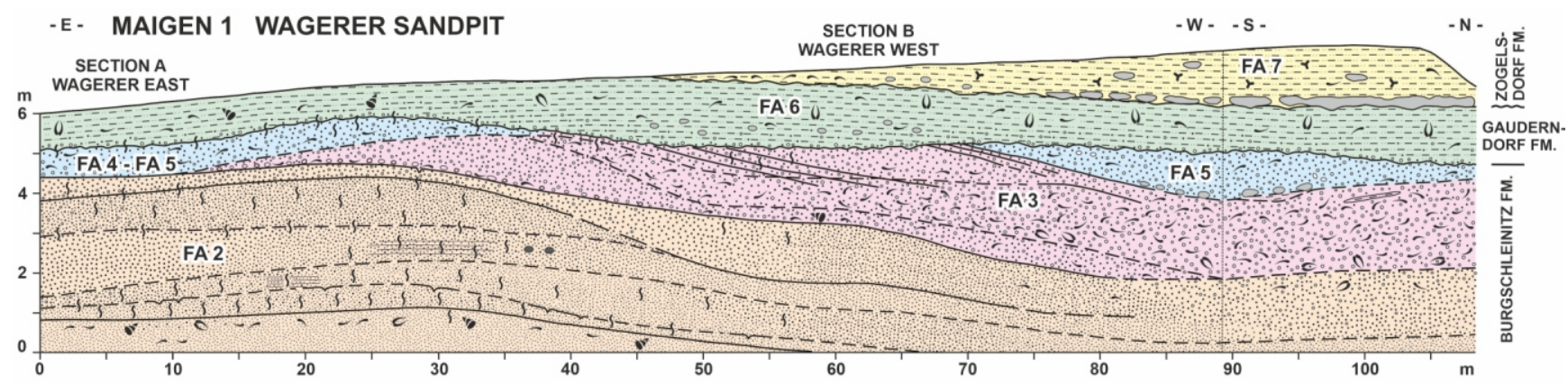

LITHOLOGY
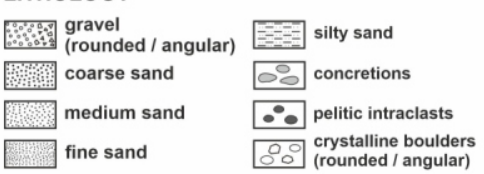

SEDIMENTARY STRUCTURES

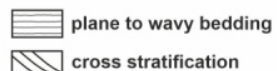

FOSSILS

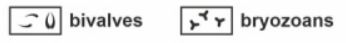

$\checkmark$ gastropods S's $^{\prime}$ trace fossils \begin{tabular}{|l|l|l}
\hline FA 7 & number of \\
facies association
\end{tabular} FA 4/5 FA 3 FA2

Fig. 9. Line drawing documenting the facies architecture (FA) and body geometries of the outcrop in the Wagerer sandpit (Maigen 1) with positions of section A Wagerer east and section B Wagerer west (situation 1985)

In contrast, these sediments are much more diverse in the Wagerer outcrop, where they form above a slightly convex lower boundary an up to $4 \mathrm{~m}$ thick convex sand-body in the eastern outcrop wall, laterally extending for at least $100 \mathrm{~m}$ and descending to the south-west (Fig. 9: FA 2). The silty fine- to medium-grained sands at the base (Fig. 5: section $B$, samples $22,1 \mathrm{~W}$, section $\mathrm{A}$, sample $1 \mathrm{E}$ ) are upward passing over into medium- to fine-grained sands (samples $2 \mathrm{~W}, 2 \mathrm{E}$ ) and coarse medium- to fine-grained sands (samples $3 \mathrm{~W}, 3 \mathrm{E}$ ) and are finally overlain at the top by medium- to coarse-grained sands (samples 4W, 4E). Besides the coarsening upward the single layers show lateral fining respectively coarsening and also reveal lateral change in thickness (Fig. 9). Some layers are in the middle part thin laminated and contain pelitic intraclasts. They are in the lower parts strongly bioturbated, causing in some layers funnel-shaped structures in bedding. Generally, the diffuse bioturbation decreases here downslope towards the west. In the top parts the sediments are intensely bioturbated by $4-5 \mathrm{~cm}$ thick clayey- and pellet-walled Ophiomorpha nodosa which are filled with coarse sand from the top. At the topmost part of this convex sand-body in the east rounded pebbles from quartz and mica-schist occur in medium- to coarse-grained sands (Fig. 5: section A, sample 4E; Fig. 9). Downslope in westward direction the sands are fining and the layer is thickening (Fig. 5: section B, sample 4W; Fig. 9). Except of few vertical shafts from burrows, the highest parts yield no fossils while the downslope sands contain rare shell fragments.

Upsection, the Burgschleinitz Formation in the Wagerer sandpit is completed by a heterogeneous and coarse-grained sediment package which is in parts cross-stratified and significantly thickening towards west to south-west. It consists of various subhorizons which are imbricated and merging from east to west (Fig. 9: FA 3). The base of this sediment package above the highest elevation of the underlying convex sand-body in the east is made up of a $20 \mathrm{~cm}$ thick layer with pebbles and cobbles from well-rounded quartz and subangular, strongly weathered mica-schist (Figs. 5 and 9). They are imbedded in a coarse sandy to fine gravelly matrix with some shell-hash and rib-fragments of seacows. This lithology, together with erosional pockets, deepened in the lower horizon, point to storm deposits. Downslope to the west this coarse-grained layer turn into a gravelly single grain layer with few internal moulds of bivalves. This basal layer is topped by angular to subangular gravelly coarse sand which is westward laterally thickening and coars- ening and better sorting with an appreciably higher content of fine gravel but fewer silt (Fig. 5: section B, sample 5W; Fig. 9: FA 3). This horizon is in the west maximally $2.2 \mathrm{~m}$ thick and is thinning and pinching out towards the east (Fig. 9). It contains a remarkable high content of shell-debris, which is increasing downslope towards the west, showing there also double-valve individuals close to the base. In upward direction, the shell-debris is decreasing in the westernmost part. The thick-shelled valves are partly concentrated in layers and are oriented parallel to a flat SSW- to SW-ward cross-stratification. Besides the valves, this cross-bedding is also accentuated by fine gravelly layers as well as thin pelitic ribbons. In the western part of the outcrop wall, the latter described cross-stratified shell-debris sand is passing over into maximally $80 \mathrm{~cm}$ thick fine gravelly coarse sand (Fig. 5: section B; Fig. 9). It is fining upward and has again a higher silty portion in the matrix. In some parts the sand is flat cross-stratified $\left(06-20^{\circ}\right.$, mainly $\left.10-15^{\circ}\right)$, marked by thin pelitic ribbons dipping in SSW-direction. The fossil content is limited to few shell-debris but in some parts, the sand is strongly bioturbated from the top.

The final, topmost horizon of the Burgschleinitz Formation in the western part of the Wagerer sandpit wall consists of maximally $1.2 \mathrm{~m}$ coarse sand with small portions of fine gravel and rare mica-schist pebbles which is fining upward (Fig. 9). The lower boundary of the horizon is tracing the dip of the cross-bedding layers below and is marked by concretions, while the top is erosively cut by the following Gauderndorf Formation. The sands contain only few single valves.

In the sedimentary successions of the sandpits Stranzl and Metzger large scale cross-stratified sands are developed in similar position (Fig. 3: section Stranzl east, sample 3-6; Fig. 6: section Metzger west, samples 4-5). They follow above thin laminated medium- to coarse-grained sands (Figs. 7 and 8 , FA 2) which form the bottomset of the above following, $\sim 3.6 \mathrm{~m}$ thick cross-stratified beds from coarse- to medium-grained sands (Figs. 7, 8 and 10, FA 3). The foresets are steeply inclined $\left(9-40^{\circ}\right.$, mainly $\left.20-35^{\circ}\right)$ and show a rhythmic alternation of 1-3 dm thick layers. Above a sharp base each cross-strata starts with up to $5 \mathrm{~cm}$ thick, slightly fine gravelly coarse-grained sand with extremely low fine portion. Above it is fining upward to 10-25 cm thick medium- to coarse-grained sand with higher portion of fine sand (Fig. 4A, C, D, I). Rarely small slipfolding on foreset planes was observed. Also rounded pelitic intraclasts and chips are sometimes imbedded in the cross-stratification. 

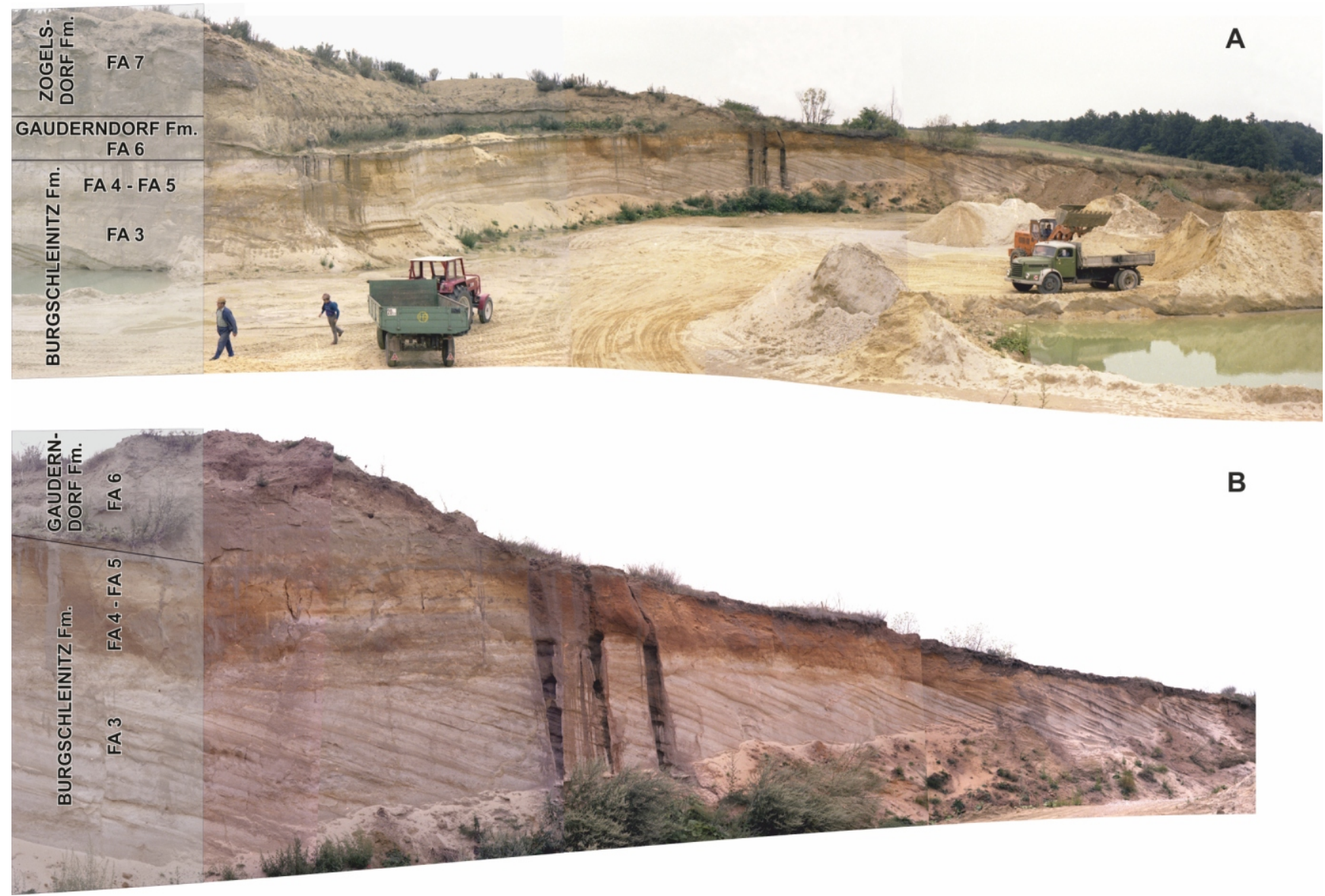

Fig. 10. Photos of the Stranzl sandpit (Maigen 2)

A - overview of the sandpit towards the east, note the geometry of the cross-stratified sands (FA 3) along the outcrop wall; B - detail view of the cross-stratified sands (FA 3) on the eastern wall (cf. Fig. 7; situation around 1975, photos by F.F. Steininger)

Bioturbation is rare and mainly observed in the topmost parts, reaching down from the above following Ophiomorpha sands.

Above or in lateral position of the cross-stratified sands follow coarse- to medium-grained sands which are characterized by strong bioturbation by Ophiomorpha nodosa (Figs. 7, 8 and 9, FA 4-FA 5). They can be considered as topsets of the cross-stratified sands of FA 3 below.

In the Stranzl sandpit the 2.5-3 m thick bed from coarse- to medium-grained sand is divided in $0.8-1.2 \mathrm{~m}$ thick layers (Fig. 3: section Stranzl east, samples 7-8; Figs. 7 and 10B). The sediments are bioturbated by Ophiomorpha nodosa, showing the highest density in the basal part (Fig. 4B).

In the Metzger sandpit the lower part is formed by at least $1.3 \mathrm{~m}$ coarse- to medium-grained sand which is slightly coarsening upward (Fig. 6: section Metzger west, sample 6) and fine bedded in the lowermost eastern part (Fig. 6: section Metzger east, sample 12; Fig. 8: FA 4). Upward, they are overlain by medium- to coarse-grained sand and at least fine gravelly coarse-grained sand (Fig. 6: section Metzger west, sample 7W; section Metzger east, sample 7E; Fig. 8: FA 5). These sediments are in all $\sim 1 \mathrm{~m}$ thick and contain subrounded quartz and more poorly rounded mica-schist. The burrowing density by Ophiomorpha nodosa is here intensifying towards the top, in parts with a remarkable thickness of the nodose and walled Ophiomorpha tubes of up to $7 \mathrm{~cm}$ (Fig. 4K).

In the Wagerer sandpit correlative sediments are $70-130 \mathrm{~cm}$ gravelly coarse-grained sands in silty to sandy ma- trix in the eastern part of the outcrop wall (Fig. 9: FA 4, 5) which can be considered as topset of the cross-stratified sands of FA 3 adjoining to the west. The sediments are poorly sorted and rounded and contain in the easternmost part some shell-fragments and bioturbation from the top (Fig. 5: section A, sample 5E).

\section{GAUDERNDORF FORMATION}

Above the Burgschleinitz Formation follow sediments of the Gauderndorf Formation in all outcrops with a sharp and wavy undulated erosional discordance. The 1-2 dm-thick basal part contains pebbles up to $5 \mathrm{~cm}$ in size from well-rounded to subrounded quartz and mica-schist in a silty to sandy matrix. In some parts of the Stranzl sandpit also silty layers with reworked mud chips were observed here.

In the Stranzl and Metzger sandpits, well-rounded fine gravel from quartz and mica-schist were also found in the above following, $\sim 40 \mathrm{~cm}$ thick medium- to coarse-sandy silt which is also fining upward (Fig. 3: section Stranzl east, sample 9; Fig. 6: section Metzger west, sample 8W; section Metzger east, sample 8E). In some parts this layer is strongly bioturbated, mainly by $1-2 \mathrm{~cm}$ thick horizontal and unwalled tunnels. Upward, the sediments pass over into max. 1.6-2 m fine sandy siltsand to silty fine sand which contain in the Stranzl sandpit scattered lenses (scours), filled with coarse-grained sand to fine gravel (Fig. 3: section Stranzl east, samples 9A, 31; 
Fig. 6: section Metzger west, sample 9W; section Metzger east, sample 9E). In the outcrops around the Wagerer sandpit, these parts generally show high portions of coarse-grained sand (Fig. 5). For the Gauderndorf Formation are typical some decimetre big, spherical limestone concretions. The silts and fine-grained sands are strongly bioturbated (Fig. 4F) by a thin-shelled, burrowing and diverse fully marine mollusc-fauna comprising mainly Solen, Barymactra, Peronaea, Cordiopsis, turritellids and naticids. From the municipal sandpit nearby the Wagerer sandpit Mandic (in Mandic and Reisinger, 1992) is listing Pharus legumen, Thracia convexa, Turritella inaequicingulata, Ficus burdigalensis, Solen marginatus, Diplodonta cf. rotundata, Peronaea planata, Cordiposis gigas, Pholadomya eggenburgensis, Terebralia lignitarum, Natica sp., Perna sp., Isognomon sp., Conus sp., Ostrea sp., Cerastoderma edule, Barymactra bucklandi, Lutraria sanna, Isognomon rollei and Balanus sp. In the Wagerer sandpit Solen marginatus were frequently found in life position, especially in the western part of the pit. In the Metzger sandpit thin-shelled bivalves were concentrated especially at the base of this layer as well as in lenses (scours?).

\section{ZOGELSDORF FORMATION}

On top of the Gauderndorf Formation another erosional discordance is separating the upward following Zogelsdorf Formation. In the Stranzl sandpit, in a first step, the relief with up to $40 \mathrm{~cm}$ deep scours was filled with sandy gravel from well-rounded quartz and angular mica-schist pebbles. This transgression-layer contains oysters, pectinids, moulds of bivalves and balanids, together with reworked, compacted sediments and aragonitic shells of gastropods and bivalves (e.g., Turritella, Cordiopsis) from the subjacent Gauderndorf Formation (Nebelsick, 1989a; cf. Nebelsick, 1989b). In the Wagerer and Metzger sandpits carbonate concretions are frequent mainly at the base, where they partly can form continuous sandstone horizons. This basal, several decimetre-thick reworked horizon is fining upward and passing over into poorly sorted, sandy limestone with biogenic components (Fig. 4J). The complete thickness of the Zogelsdorf Formation is in the Stranzl sandpit up to $4.3 \mathrm{~m}$, in the Wagerer sandpit maximally $1.45 \mathrm{~m}$ and in the Metzger sandpit $\sim 3 \mathrm{~m}$.

In the Stranzl sandpit in the lower $1.2 \mathrm{~m}$ sandy limestone from silty, fine to medium sand with few well-rounded quartz-gravel some moulds of glycymerids occur (Fig. 3: section Stranzl east). Coarsening upward sediments are passing over in $1.8 \mathrm{~m}$ silty and gravelly, medium to coarse sand with layers of pectinids in coarser parts and abundant concretions (Fig. 3: section Stranzl east, sample 32). In the topmost part of the section, the sediments again are finer and show in some layers more frequently coralline algae. Such coarsening upward was also observed in the Metzger sandpit (Fig. 6: section Metzger west, sample 10W; section Metzger east, samples 10E, 11E).

In the Zogelsdorf Formation around Maigen mainly bryozoans and molluscs prevail, together with echinoderms and subordinately coralline algae (cf. Nebelsick, 1989b). Mandic (in Mandic and Reisinger, 1992) is citing from the Zogelsdorf Formation in the municipal sandpit nearby the Wagerer sandpit Discors discrepans, Gigantopecten holgeri, Cardita crassa, Pecten hornensis, Peronaea planata, Anomia ephippium, Helminthia aff. vermicularis, Cordiopsis sp., Glycymeris fichteli, G. deshayesi, Paroxystele orientale, Natica sp., Ostrea sp., Celepora sp., Vermetus sp. and Balanus sp.

\section{RESULTS}

\section{FACIES ANALYSIS}

Lithofacies of the deposits of the succession studied in three separated outcrops on the locality Maigen have been organized into seven facies associations (FA). These FA are: (1) gravel and muddy sands; (2) subhorizontal beds of fossiliferous sands; (3) large scale cross-stratified sands; (4) subhorizontal beds of cross-stratified sands; (5) Ophiomorpha sands; (6) fining upward gravels to silty sands; (7) sandy gravels and bioclastic limestones. These FA can be assigned to the Lower Miocene lithostratigraphic units of the Alpine-Carpathian Foredeep in the region. Deposits of FA 1 represent the Kühnring Member. Deposits of FA 2, 3, 4 and 5 represent the Burgschleinitz Formation, which are the principal target of this article and the volumetrically predominant part of the studied succession. Overlying deposits of the Gauderndorf Formation and Zogelsdorf Formation are represented by the last two facies associations, i.e. FA 6 and FA 7. Because these younger deposits are not target of this article, they are not studied and discussed in detail.

Detailed descriptions (lithology, stratification and sedimentary structures) and interpretation of each recognized facies are given in Table 1. Logs and line drawings, illustrating the distribution of facies associations from outcrops, are presented in Figures 3 and 5-10. Examples of both lithofacies and facies associations within the logged sections can be followed in Figure 4.

FA 1 - GRAVEL AND MUDDY SANDS

FA 1 is composed of silty coarse-grained sands of facies Sgm and gravel of facies $G$ (see Table 1). Gravel of facies $G$ are composed of angular to subangular clasts of mica-schist and paragneiss as well as subrounded to rounded quartz pebbles, which can reach up to $10 \mathrm{~cm}$ in diameter. The pebbles are frequently matrix supported in a matrix of silty sand to coarse-grained sand. Sands of facies Sgm are poorly sorted due to the admixture of silt and especially the occurrence of granules and small pebbles. Several oyster-horizons within beds of facies Sgm were observed. These deposits are bioturbated and fossiliferous (see description above).

FA 1 is developed immediately above the crystalline basement and forms the lowermost part of the studied Lower Miocene succession. The total thickness of FA 1 highly varies and is influenced by the actual shape of the basement, but usually reaches several decimetres to one metre, in some cases also more. The base of FA 1 is irregular, sharp and erosive and the top is generally flat and/or convex up. FA 1 is overlain by deposits of FA 2.

Interpretation: The direct position above the crystalline basement, a poor sorting and admixture of both mud and coarse clasts as well as angular basement material together with rounded quartzes point to reworked deposits. Furthermore, by the mixed (marine, brackish and terrestrial) fossil fauna for FA 1 a deposition as a transgressive lag in an estuary or coastal lagoon, respectively (Nalin and Massari, 2009; Zecchin et al., 2009) can be assumed.

Preservation and deposition of the Kühnring Member (i.e. FA 1) were highly influenced by the bedrock surface, which is also supported by data from geological mapping (Fig. 2). For instance, a striking presedimentary basement relief was well documented in the Stranzl sandpit (Maigen 2) where altitude differences of up to $12 \mathrm{~m}$ were verified in bedrock elevations. 
Brief description and interpretation of lithofacies in the studied outcrops,

FA refers to the facies associations characterized in this paper

\begin{tabular}{|c|c|c|c|}
\hline \multicolumn{4}{|c|}{ Subhorizontal beds } \\
\hline Symbol & FA & Description & Interpretation \\
\hline G & $\begin{array}{l}\text { FA } 1 \\
\text { FA } 6 \\
\text { FA } 7\end{array}$ & $\begin{array}{l}\text { Gravel, composed of angular to subangular pebbles and rare } \\
\text { cobbles of mica schist, paragneiss and subrounded to rounded } \\
\text { pebbles of quartz. Mostly clast-supported; however, locally and in } \\
\text { FA } 1 \text { sand matrix-supported. Preferred orientation of pebbles not } \\
\text { recognized. Facies G drapes a erosional surface with dm-relief. } \\
\text { Dm-scale slightly irregular bed with sharp top. }\end{array}$ & $\begin{array}{l}\text { Transgressive lag (Demarest and } \\
\text { Kraft, 1987; Nummedal and Swift, } \\
\text { 1987), reworking of older deposits } \\
\text { and fresh eroded crystalline } \\
\text { basement material (Nalin and } \\
\text { Massari, 2009; Zecchin et al., 2009) } \\
\text { or storm lag (Clifton, 2006). } \\
\end{array}$ \\
\hline $\mathrm{Sgl}$ & FA 2 & $\begin{array}{l}\text { Green-grey to yellowish brown silty fine-grained and partly planar } \\
\text { parallel laminated sands, in parts with admixture of well-rounded } \\
\text { medium to coarse sand and fine gravel. } \\
\text { Common occurrence of molluscs in decimetre-thick fossiliferous } \\
\text { layers, mainly from Granulolabium or Ostrea and Perna. Topward a } \\
\text { fully marine mollusc fauna with Peronaea, Turritella, } \\
\text { Granuiolabium, Cerastoderma, Natica, Cordiopsis, Paroxystele, } \\
\text { Perna and Ostrea. }\end{array}$ & $\begin{array}{l}\text { Deposition above the fair weather } \\
\text { base mainly from heavily loaded } \\
\text { suspension clouds generated by } \\
\text { storms or gravity currents. Well- } \\
\text { oxygenated marine conditions. } \\
\text { Sudden changes in the sedimentary } \\
\text { conditions (Clifton, 2006; Nielsen } \\
\text { and Johannessen, 2009). }\end{array}$ \\
\hline Sgm & FA 1 & $\begin{array}{l}\text { Yellow-brown to green-grey, silty sand to coarse-grained sand, } \\
\text { poorly sorted. Significant admixture of small gravels with } \\
\text { subangular pebbles of crystalline rocks. High content of bioclasts } \\
\text { (corals, molluscs - Ostrea, Perna, Glycymeris, Turritella, } \\
\text { Granulolabium, Paroxystele, Cordiopsis and Cerastoderma, } \\
\text { otoliths, bones and teeth of small mammals). }\end{array}$ & $\begin{array}{l}\text { Mixed transgressive lag (Demarest } \\
\text { and Kraft, 1987; Nummedal and } \\
\text { Swift, 1987), or storm lag (Clifton, } \\
\text { 2006) with deposits of partly } \\
\text { protected brackish environment } \\
\text { (lagoon). }\end{array}$ \\
\hline SI & FA 5 & $\begin{array}{c}\text { Fine to very fine sand, well sorted, plane parallel stratified. } \\
\text { Lamination is highlighted by alternation of coarser and finer grained } \\
\text { intervals. Horizontal beds, tabular to wedge shaped. Bed thickness } \\
\text { up to } 20 \mathrm{~cm} \text {. }\end{array}$ & $\begin{array}{l}\text { Deposition of fluctuating oscillatory } \\
\text { flows (Komar and Miller, 1975; } \\
\text { Clifton, 2006). }\end{array}$ \\
\hline Slb & $\begin{array}{l}\text { FA } 5 \\
\text { FA } 6\end{array}$ & $\begin{array}{l}\text { Coarse- to very coarse-grained sand, poorly sorted due to } \\
\text { admixture of isolated pebbles (up to } 3 \mathrm{~cm} \text { across, mostly }<1 \mathrm{~cm} \text {, } \\
\text { mostly subrounded quartz, rare mudstone clasts). Inclined plane } \\
\text { parallel stratification (dip of inclination up to } 5^{\circ} \text { ). Index of } \\
\text { bioturbation varies between } 2 \text { and } 3-\text { Ophiomorpha traces. } \\
\text { Horizontal, tabular shape of beds. Set thickness up to } 1 \mathrm{~m} \text {. Sharp } \\
\text { broadly convex down base. Sharp flat top. }\end{array}$ & $\begin{array}{l}\text { Combination of action of strong } \\
\text { waves or currents and low-energy } \\
\text { settings, suitable for colonisation of } \\
\text { the substrate recorded by } \\
\text { bioturbation. Shoreface depositional } \\
\text { environment (Reading and } \\
\text { Collinson, 1996; Clifton, 2006). }\end{array}$ \\
\hline $\mathrm{Sp}$ & FA 4 & $\begin{array}{l}\text { Coarse- to very coarse-grained sand, planar cross-stratified. Poorly } \\
\text { sorted due to scattered granules and admixture of medium-grained } \\
\text { sand. Coset/bed thickness up to } 1.2 \mathrm{~m} \text {, consists of dm-scale sets. } \\
\text { Set thickness varies between } 10 \text { and } 30 \mathrm{~cm} \text {. Flat sharp base, } \\
\text { irregular slightly undulated top. Tabular, horizontal beds, foresets } \\
\text { inclined } 10^{\circ} \text { to } 20^{\circ} \text {. Mostly angular shape of cross-stratification. } \\
\text { However, in places the tangential one can be followed. } \\
\text { Palaeocurrent directions are mostly directed toward south-west. }\end{array}$ & $\begin{array}{l}\text { Action of strong unidirectional } \\
\text { currents leading to formation of } 2 \mathrm{D} \\
\text { dunes. Upper shoreface deposits } \\
\text { formed probably by longshore } \\
\text { currents (Clifton, 1981; Massari and } \\
\text { Parea, 1988; Hart and Plint, 1995: } \\
\text { Clifton, 2006). Erosional base may } \\
\text { be associated with seaward } \\
\text { migration of longshore troughs } \\
\text { during progradation (Hunter et al., } \\
\text { 1979). }\end{array}$ \\
\hline St & FA 4 & $\begin{array}{l}\text { Light grey, yellow to yellow-brown, fine, medium or medium- to } \\
\text { coarse-grained sand, trough cross-stratified. Mostly poorly sorted } \\
\text { due to admixture of scattered granules and grains of very coarse } \\
\text { sand. Set thickness up to } 15 \mathrm{~cm} \text {, cosets about } 40 \text { to } 80 \mathrm{~cm} \text { thick. } \\
\text { Erosive, broadly concave base. Sharp, flat, commonly slightly } \\
\text { inclined tops. }\end{array}$ & $\begin{array}{l}\text { Action of strong unidirectional } \\
\text { currents leading to formation of } 3 D \\
\text { dunes. Upper shoreface deposits. }\end{array}$ \\
\hline Sw & FA 5 & $\begin{array}{l}\text { Medium- to coarse-grained sand, well sorted, wave ripple cross- } \\
\text { lamination, undulated base. Mostly erosional relic, up to } 5 \mathrm{~cm} \text { thick. }\end{array}$ & $\begin{array}{l}\text { Oscillating currents transporting } \\
\text { sediments along the bottom }\end{array}$ \\
\hline $\mathrm{Su}$ & FA 5 & $\begin{array}{l}\text { Fine or fine- to medium-grained sand, poorly sorted due to } \\
\text { admixture of rare rounded quartz pebbles up to } 3 \mathrm{~cm} \text { in diameter, } \\
\text { Flaser to undulated stratification. Discontinuous flasers of dark grey } \\
\text { mud, max. } 1 \mathrm{~cm} \text { thick. Scattered mudstone chips a few cm large. }\end{array}$ & $\begin{array}{l}\text { Storm-generated combined action of } \\
\text { waves and unidirectional currents } \\
\text { (Johnson and Baldwin, 1996; } \\
\text { Dumas and Arnott, 2006). }\end{array}$ \\
\hline Ls & FA 7 & $\begin{array}{l}\text { Medium- to coarse-grained bioclastic limestones to calcareous } \\
\text { sands. The tabular shaped and indistinct bedded sediments are up } \\
\text { to } 4.3 \mathrm{~m} \text { thick. Highly burrowed, abundant shells. }\end{array}$ & $\begin{array}{l}\text { Lower shoreface deposits to inner } \\
\text { shelf deposits (Clifton, 2006) }\end{array}$ \\
\hline Smf & FA 2 & $\begin{array}{l}\text { Silty fine- to medium-grained, structureless/massive sands. These } \\
\text { sands are coarsening upward into partly laminated, medium to fine } \\
\text { sands. Top parts from coarse medium to fine sands are } \\
\text { significantly bioturbated. }\end{array}$ & $\begin{array}{l}\text { Deposition above the fair-weather } \\
\text { base in well-oxygenated marine } \\
\text { conditions. Biogenic activity } \\
\text { obliterated the primary sedimentary } \\
\text { structures. }\end{array}$ \\
\hline Fs & FA 6 & $\begin{array}{l}\text { Fine- to very fine-grained silty sands with remnants of even to } \\
\text { undulating stratification obliterated by burrows. Common } \\
\text { occurrence of thin-shelled bivalves. Tabular, medium to thick } \\
\text { bedding. Sharp, slightly undulated, erosive top. }\end{array}$ & $\begin{array}{l}\text { Deposition in a protected area, } \\
\text { mostly from suspension with a } \\
\text { distant influence of currents. Intense } \\
\text { biogenic activity. }\end{array}$ \\
\hline M & FA 5 & $\begin{array}{c}\text { Dark grey mudstone, massive. Erosional relict max. } 2 \mathrm{~cm} \text { thick. } \\
\text { Undulated sharp base, erosive top. }\end{array}$ & Suspension deposits. \\
\hline
\end{tabular}


Tab. 1 cont.

\begin{tabular}{|c|c|c|c|}
\hline \multicolumn{4}{|c|}{ Steeply inclined/foreset beds $\left(10-35^{\circ}\right)$} \\
\hline Symbol & FA & Description & Interpretation \\
\hline Sr & $\begin{array}{l}\text { FA } 3 \\
\text { FA } 4\end{array}$ & $\begin{array}{l}\text { Light yellow to yellow-brownish, fine or fine- to very fine-grained } \\
\text { sand, ripple cross-lamination. Well sorted. Individual beds are max. } \\
4 \mathrm{~cm} \text { thick and mostly discontinuous, forming interbeds within the } \\
\text { facies Sll. Sharp base, sharp erosive top. }\end{array}$ & $\begin{array}{l}\text { Oscillatory and unidirectional } \\
\text { currents. }\end{array}$ \\
\hline SII & FA 3 & $\begin{array}{l}\text { Light yellow to yellowish brown, reddish mottled, fine to medium, } \\
\text { medium or medium to coarse-grained sand with large-scale (almost } \\
4.0 \mathrm{~m} \text { ) cross-bedding i.e. foreset. Dip angle varies between } 9^{\circ} \text { and } \\
40^{\circ} \text {. Decline of the slope angle was recognised close to the top or } \\
\text { bottom of the foresets, so they have tangential or sigmoidal } \\
\text { boundaries. Some variations in the orientation of bedding of } \\
\text { successive beds were recognized. These reactivation surfaces are } \\
\text { highlighted by scattered granules, they are mostly slightly convex } \\
\text { down and generally sharp. Individual beds have thickness between } \\
7 \text { and } 30 \mathrm{~cm} \text {. The total thickness of the SIl unit is up to } 3.6 \mathrm{~m} \text {. The } \\
\text { sand is poorly sorted due to admixture of scattered grains of } \\
\text { coarse- to very coarse-grained sand. Individual laminae of very } \\
\text { coarse sand were observed very rarely. Foreset stratification is } \\
\text { highlighted by alternation of slightly finer and coarser grained } \\
\text { intervals. Stratification is sometimes disturbed from the top by } \\
\text { Ophiomorpha traces. }\end{array}$ & $\begin{array}{l}\text { Product of avalanche processes } \\
\text { down the steep subaqueous slope } \\
\text { (Nielsen et al., 1988). }\end{array}$ \\
\hline
\end{tabular}

A connection between the estuarine deposits of the Kühnring Member and a palaeovalley running from the north-west is proven by field data.

However, profile and morphology of the palaeovalley was significantly affected by the actual shape of the crystalline surface. The lithology of the sedimentary infill of this palaeovalley with fluvial-estuarine deposits of the Rodingersdorf Formation is comparable with the upper Oligocene St.Marein-Freischling Formation in the Horn Basin (Nehyba and Roetzel, 2010). The base of FA 1 represents a sequence boundary.

FA 2 - SUBHORIZONTAL BEDS OF FOSSILIFEROUS SANDS

FA 2 is represented by horizontal to subhorizontal (dip $<5^{\circ}$ ) laterally continuous beds, which consist of two facies, i.e. Sgl and Smf (see Table 1 for detailed description). Silty fine-grained and partly planar parallel laminated sands, which in some parts also have admixture of well-rounded medium to coarse sand and fine gravel, represent the volumetrically dominant facies Sgl. Generally, a fining upward trend was recognized due to a decrease of coarse sand and granules toward the top of the beds of Sgl. The thickness is varying between $\sim 1.3$ and $3.4 \mathrm{~m}$. The sands are fossiliferous, mainly from Granulolabium and horizons of Ostrea and Perna, which upward pass over into a species-rich and fully marine mollusc-fauna.

The subordinate facies Smf is made up by silty fine- to medium grained structureless/massive sands, which are coarsening upward into partly thin laminated medium- to fine-grained sands. On top are coarse medium- to fine-grained sands developed, which are strongly bioturbated. Grain size is also laterally changing and in some cases, the intensity of the bioturbation decreases laterally too.

The deposits of FA 2 reveal a generally tabular shape of beds and convex upper boundary, which can be followed in outcrops for $\sim 60$ to $100 \mathrm{~m}$, submerging towards the west and south-west. The total thickness of FA 2 is $\sim 0.5 \mathrm{~m}$ to several metres. Sands of FA 2 are better sorted than deposits of FA 1 , which they cover along a flat or slightly convex base. Their top and contact with overlying deposits of FA 3 is generally sharp and concave upward.

Interpretation: The prevalent fine-grained nature of sand with autochthonous marine bivalves reveals a nearshore deposition above the fair-weather wave base. The planar lamination and the coarse-grained interbeds are interpreted as deposited mainly from heavily loaded suspension clouds generated by storms (Clifton, 2006; Nielsen and Johannessen, 2009) or gravity currents (see overlying FA 3) without significant influence of bottom currents. The primary sedimentary structures were partly distorted by bioturbation. The alternation of layers with preserved parallel laminated sand and massive/bioturbated sand, similarly as variations in grain size and content of fossils, indicate sudden hydrodynamic changes in the conditions of deposition. The occurring molluscs support well-oxygenated fully marine conditions. The upward coarsening and increasing amount of granules in the topmost parts of FA 2 is interpreted as indication of shallowing and transition to the deposits of overlaying FA 3. Sediments of FA 2 are interpreted as deposits of middle to lower shoreface influenced by the prograding bars and action of storms (Clifton, 2006). The limited scouring, tabular shape and, in parts, relatively large thickness of FA 2 suggest deposition under relatively protected deeper conditions (Nielsen and Johannessen, 2009).

FA 3 - LARGE SCALE CROSS-STRATIFIED SANDS

This facies association represents the most prominent feature of the studied succession. FA 3 consists of steeply inclined and laterally continuous sandy beds, relatively consistently dipping in SE, S to SW directions (Maigen 1: 185-252 ${ }^{\circ}$, Maigen 2; $160-258^{\circ}$, Maigen 3: $130-200^{\circ}$ ). FA 3 comprises two lithofacies (SII and Sr) however, cross-stratified sands of lithofacies SII strongly predominate forming $>93 \%$ of the relative thickness of FA 3 (Figs. 4A, C, I and 10).

Lithofacies SII is made up of steeply inclined $\left(09-40^{\circ}\right.$, mainly $20-35^{\circ}$ ) gravelly coarse, coarse- and medium-grained sands, which show a decimetre-thick rhythmic alternation. Each cross-strata has a sharp base and starts with up to $5 \mathrm{~cm}$ thick, slightly fine gravelly coarse sand with extremely low fine portion. Upward it is fining to $10-25 \mathrm{~cm}$ thick medium to coarse sand with higher fine portion (Fig. 4A, C, I). Rarely small slipfolds on foreset planes and rounded pelitic intraclasts and chips were observed. The subordinate ripple cross-laminated sands of lithofacies Sr form only discontinuous and maximum several $\mathrm{cm}$ thick interbeds within the prevalent beds of lithofacies SII. For detailed description of both lithofacies see Table 1. 
The vertical thickness of FA 3 in sections varies between 125 and $360 \mathrm{~cm}$ in individual outcrops. The contact of FA 3 and FA 2 is sharp and concave-upward. Significant reduction of the dip of beds of FA 3 towards the base is relatively common, so the basal contact is mostly tangential, less frequent angular. The contact with the overlying FA 4 is sharp and generally undulated. Reduction of the dip of the beds of FA 3 towards the top was also recognized, however, it seems to be less common than the reduction of the dip towards the base. Therefore, the top contact can be described as either angular/oblique or sigmoidal. Usually, shells have not been observed frequently, although, they occur in some parts of FA 3 in outcrop 1 (Maigen Wagerer, Kainrath and municipal sandpit), covering the lee-sides of cross-stratified foresets. Bioturbation is rather scattered and uncommon (especially in comparison to FA 4 and FA 5) and mainly observed in the topmost parts, reaching down from the above following FA 4 (Fig. 4D, I). Bioturbation index $\mathrm{BI}$ (Droser and Bottjer, 1986) is 0 to max. 1.

Interpretation: The lithofacies assemblage indicates the steep foresets strongly dominated by deposition of sediment gravity-flows (Nemec, 1990). Well-stratified beds of facies SII are interpreted as product of avalanche processes down the steep subaqueous slope (Nielsen et al., 1988), probably induced by strong nearshore currents. The almost regular internal alternation between fine- and coarse-grained layers suggest deposition from pulsating currents (Nielsen et al., 1988). The sporadic intrasets of facies $\mathrm{Sr}$ are interpreted as deposited by occasional both oscillating and unidirectional currents transporting sediments along the steep subaqueous slopes and partly reworked the dune slip faces. Reactivation surfaces and rare occurrences of mud clasts reveal variations in the current activity, orientation and velocity. The scattered burrows indicate rather quiet periods when organisms have settled on the bottom without being disturbed by avalanching. The deposits of FA 3 are interpreted as foresets of a coastal spit, more precisely as a spit platform front (e.g., Dott and Bourgeois, 1982; Nielsen et al., 1988; Dumas et al., 2005; Nielsen and Johannessen, 2009). Allen (1982) interpreted the isolated, relatively thick planar cross-sets as small longshore bars migrating oblique to the shoreline. Generally, SW- to SSE-ward inclination of the foresets indicates sediment transport roughly from NE and N. The relatively small variations in transport direction indicate periods of stable depositional conditions characterized by strong unidirectional currents, high sand supply and sufficient accommodation space to allow most of the dunes to be preserved.

Relatively flat base and the alternation of angular and tangential basal contact point to fluctuation of the flow velocity along the slope and changes in the depth-ratio (Jopling,1965). Evidence of backflows was only occasionally recognized. Such conditions are probably connected with relatively higher depth-ratio (sensu Jopling, 1965), relatively low angle lee-side of migrating bedforms with some traction current activity and relatively flat foreset profile. Although, truncation and reactivation surfaces were relatively common within foreset beds, mostly they are only gently undulated and often less inclined than the underlying strata. Evidence of both sigmoidal and oblique brink and variations in the brink trajectory reveals variations in the accommodation available for bar front aggradation and existence of individual bar lobes or recurved spit. An overall upward increase in biogenous activity reflects the decreasing depositional energy (into FA 5).

$$
\text { FA } 4 \text { - SUBHORIZONTAL BEDS OF CROSS-STRATIFIED SANDS }
$$

These sandy deposits form $\sim 1.5 \mathrm{~m}$ thick tabular to broadly lenticular bodies. Horizontal beds of FA 4 are made up of three lithofacies i.e. St, Sp and Sr (see Table 1) however, lithofacies St and Sp strongly predominates, comprising $99 \%$ of the rela- tive thickness of FA 4. Facies $\mathrm{Sr}$ forms max. several $\mathrm{cm}$ thick interbeds covering the underlying sets of facies St and is erosively cut by overlying sets of facies St. Deposits of FA 4 are bioturbated mostly by burrows of Ophiomorpha and $\mathrm{BI}$ is 1 (Fig. 4B, K). Scattered well-rounded small pebbles (up to some centimetre in diameter) can be enriched along the base of FA 4 and are rarer within the bed. The thickness of sets of facies St varies from 10 to $15 \mathrm{~cm}$, the coset thickness is $\sim 40$ to $80 \mathrm{~cm}$. The thickness of sets of facies Sp varies from 10 to $30 \mathrm{~cm}$, the coset thickness is $\sim 120 \mathrm{~cm}$. The base of FA 4 is erosive, slightly undulated and generally broadly convex down where it covers the deposits of FA 3 (Figs. 4C and 10). Deposits of FA 4 alternate with deposits of FA 5 and are finally covered by them.

Interpretation: The range of stratification types and the lack of argillaceous interlayers indicate a deposition in a wave-worked upper shoreface environment (Clifton, 1981; Hampson, 2000). Tabular beds of trough cross-stratified and/or planar cross-stratified medium- to coarse-grained sand are interpreted as formed by strong unidirectional littoral currents leading to formation of 3D (linguoid or lunate) dunes and/or 2D dunes (Clifton and Dingler, 1984). The development of dunes is commonly linked to nearshore circulation cells of longshore currents (Clifton, 1981; Massari and Parea, 1988; Hart and Plint, 1995; Clifton, 2006). The thin interbeds of facies Sr represent deposits of ripples covering the dunes. The alternation of trough cross-stratified beds with subordinate ripple cross-lamination indicates fair-weather wave action with generally high but fluctuating orbital velocities (Clifton et al., 1971; Komar and Miller, 1975). The poor preservation of Sr indicates high sediment input, relatively rapid deposition and migration of larger bedforms, i.e. dunes. The longshore migration of 2D or 3D dunes was probably controlled by the palaeoshoreline trend. When they reached a topographic step on the basement, the forests (i.e. FA 3) start to develop due to transformation of the longshore currents to gravity-flow processes (Zecchin et al., 2010). The deposits of FA 4 therefore are interpreted as the topset deposits of a spit.

Erosional slightly convex down base of FA 4 and palaeocurrent directions mostly toward south-west (i.e. obliquely in regard to the large-scale clinoform foreset of FA 3) might signalize an oblique bar-trough system developed within the topset deposits (Nielsen et al., 1988).

The sharp concave down base of FA 4 in a larger scale could promote the existence of a relatively protected environment, which was successively beneficial for biogenous activity (suspension feeding, dwelling) recorded by Ophiomorpha burrows. The trace fossil assemblage with Ophiomorpha reflects a well-oxygenated and nutrient-rich shoreface environment.

Double mud drapes and other tidal signatures were not noticed. Only in the municipal sandpit west of the Wagerer sandpit few indications for backflow could be observed by reverse oriented shell-hash on low angle cross-stratified foresets (Fig. 4G, L). Such a poor evidence of reversal flow suggests that tidal currents have not played a significant role in the generation of the observed sedimentary structures and/or their role was locally restricted.

The deposits of FA 4 are interpreted as upper shoreface deposits (Clifton, 1981; Massari and Parea, 1988; Hart and Plint, 1995; Clifton, 2006) and its erosional base may be related to the seaward migration of longshore troughs during progradation of the littoral bars (Hunter et al., 1979).

FA 5 - OPHIOMORPHA SANDS

Horizontal beds of FA 5 are composed by lithofacies $\mathrm{Slb}, \mathrm{SI}$, Sw, Su and M (Fig. 4B, E). These sandy deposits form $\sim 1$ to $3.3 \mathrm{~m}$ thick tabular to broadly lenticular bodies. Dominant facies Slb comprises $77 \%$ of relative thickness of FA 5 . 
It is represented by $0.8-1.2 \mathrm{~m}$ thick sets of coarse- to medium-grained sands and gravelly sands bioturbated by Ophiomorpha nodosa. Individual sets vary in intensity of bioturbation and grain size. Some sets reveal coarsening or fining upward trends. Cosets of Slb are 2.5-3 m thick. Subrounded quartz and sub-angular mica-schist form granules and small pebbles. Parallel or slightly undulating lamination is still visible in less intensely bioturbated sands. The walled bioturbation tubes are sometimes quite thick $(6-7 \mathrm{~cm})$ and mainly vertical. In three-dimensional reconstructions of these Ophiomorpha burrowing-systems preferred orientation with two orthogonal axial distributions was identified (Hohenegger and Pervesler, 1985). The approx. N-S directed orientation roughly corresponds with the current direction forming foresets of the cross-stratified FA 3 sediments below.

Facies Sw and SI form only several $\mathrm{cm}$ thick layers of mainly fine- to medium-grained sand (Fig. 4E). The occurrences of mudstones of lithofacies $\mathrm{M}$ are only a few $\mathrm{cm}$ thick discontinuous erosional relics. The shapes of deposits of facies Su are very uneven being strongly influenced by subsequent erosion and development of FA 6 . Significant variations were recognized in both sorting and intensity of bioturbation. Whereas facies $\mathrm{SI}, \mathrm{Sw}$ and $\mathrm{M}$ are relatively well sorted, facies Su and especially SIb reveal poor sorting. BI varies between 0 or 1 (facies $\mathrm{M}$, $\mathrm{SI}$, Sw and Su) to 3 (facies Slb).

The deposits of FA 5 alternate with deposits of FA 4. The bases of deposits of FA 5 are generally flat and sharp. In the Wagerer sandpit the base is tracing the dip of the cross-bedding layers below and is marked by concretions. The top of FA 5 is flat and sharp if deposits of FA 4 are in their superposition. However, an erosive and undulated top was recognized when FA 5 is overlain by deposits of FA 6 (Gauderndorf Formation).

Interpretation: The dominant facies SIb reveals a combination of strong wave action or strong currents and low-energy settings, suitable for colonisation of the substrate recorded by bioturbation. Such conditions can be located in a lower shoreface depositional environment (Reading and Collinson, 1996; Clifton, 2006). Action of waves is promoted by occurrences of lithofacies Sw and well sorted fine-grained lithofacies Sl. The planar parallel lamination alternating with wave-ripple cross-lamination indicates generally high but fluctuating orbital velocities (Clifton et al., 1971; Komar and Miller, 1975). Fine-grained sands of lithofacies Su with undulated lamination resembles swaley stratifications and is interpreted as result of storm-generated combined flow action (Johnson and Baldwin, 1996; Dumas and Arnott, 2006). Similarly, the muddy interlayers could indicate the deposition above the mean fair-weather wave base in a lower shoreface environment (Clifton, 1981; Hampson, 2000).

The deposits of FA 5 are intimately associated with the upper-shoreface deposits of FA 4, which they underlie in the regressive settings and overlie in the transgressive settings. Such an association reflects small variations in the relative sea level on the surface of the littoral bar. The lack of beach deposits within the beds of FA 4 and FA 5 is probably a result of the palaeogeographic position in the Eggenburg Bay and truncation by shoreface erosion (Hiroki and Masuda, 2000). The trace fossil assemblage reflects a well-oxygenated and nutrient-rich shoreface environment.

FA 6 - FINING UPWARD GRAVELS TO SILTY SANDS

The tabular to broadly lenticular deposits of FA 6 are composed by fining upward succession of lithofacies G, SIb and Fs and are $\sim 1-2 \mathrm{~m}$ thick. The thin bed of the basal facies $\mathrm{G}$ drapes a wavy erosional surface with an undulated relief and has an only slightly irregular sharp top. Well-rounded to subrounded quartz and mica-schist pebbles (up to $5 \mathrm{~cm}$ across), embedded in a silty to sandy matrix make up facies $\mathrm{G}$. The overlying medium- to coarse-grained sands of facies SIb are relatively poorly sorted due to admixture of scattered granules of crystalline rocks and form thin beds. In some parts, also silty layers with reworked mud chips were documented. Facies Slb passes upwards into thick beds of fine-grained fossiliferous sands of facies Fs (Fig. 4F) sometimes passing upwards into silty sands with scattered lenses (scours), filled with coarse-grained sand and fine gravel. Facies Fs forms the predominant part of the FA 6. $\mathrm{BI}$ of facies $\mathrm{SIb}$ and $\mathrm{Fs}$ is $\sim 3$ to 4 . Typical for FA 6 is a diverse thin-shelled bivalve-fauna, which frequently is concentrated especially at the base of layers of Fs.

Interpretation: The sediments of FA 6 belong to the Gauderndorf Formation. The basal gravel layer above the lower shoreface deposits of FA 5 is interpreted as a transgressive or storm lag (Clifton, 2006). Poorly sorted sands of facies Slb represent the lower shoreface. The above following fine silty sands with a diverse and thin-shelled mollusc-infauna of facies Fs can be characterized as lower shoreface deposits under calm fair-weather conditions in protected areas of the Eggenburg Bay.

\section{FA 7 - SANDY GRAVELS AND BIOCLASTIC LIMESTONES}

These tabular shaped and indistinct bedded sediments are up to $4.3 \mathrm{~m}$ thick. The lowermost part of FA 7 consists of sandy gravel of lithofacies $\mathrm{G}$, which drapes an erosional surface with several decimetre relief cut into deposits of FA 6. Pebbles are from well-rounded quartz, angular mica-schist and amphibolite. The coarse-grained layer contains mainly calcitic shells from mollusc, moulds of bivalves, balanids and reworked material from the underlying FA 6.

Facies $\mathrm{G}$ passes over into several metre thick deposits of facies Ls which form the main part of FA 7. The facies Ls consist of poorly sorted silty and gravelly medium- to coarse-grained bioclastic limestones, sandy limestones and calcareous sands with bryozoans, bivalves, echinoderms and subordinately coralline algae (Fig. 4J). Clastic components vary from silty fineto medium-grained sand with few well-rounded quartz gravel. Beds of facies Ls are variously consolidated.

Interpretation: The basal erosional gravel layer above the lower shoreface deposits of FA 6 is interpreted as a transgressive lag. It is linked with reworking of older deposits and also fresh eroded crystalline basement material and their incorporation (Demarest and Kraft, 1987; Nummedal and Swift, 1987; Hwang and Heller, 2002; Cattaneo and Steel, 2003; Nalin and Massari, 2009; Zecchin et al., 2009). Facies Ls presumably characterize dynamic depositional conditions, where wave action is typifying a shoreface (Clifton, 2006). Numerous bioclasts testify the colonization of the substrate. The deposits of FA 7 belong to the Zogelsdorf Formation and are separated by a sharp and distinct unconformity with reworked material from the underlying Gauderndorf Formation (FA 6) in their basal part (Nebelsick, 1989a, b; Piller et al., 2007). They represent a new transgressive sedimentary cycle (as was further confirmed by results of provenance analysis; see chapter "Grain size and provenance study"). The contact between FA 6 and FA 7 is a sequence boundary (Late Eggenburgian/Ottnangian; Ottnangian transgression phase).

\section{SPIT SYSTEM}

Deposits of FA 3 show the most distinct and unique feature of the Burgschleinitz Formation in the sandpits of the Maigen 
area. Steeply inclined and almost $4 \mathrm{~m}$ high foreset beds of FA 3 superimpose FA 2 and are covered by subhorizontal beds of FA 4 and FA 5. This situation implies a topset, foreset and bottomset structure commonly interpreted as deposits of a Gilbert-type delta. However, beds in the topset positions (FA 4 and FA 5) lack any evidence of fluvial activity and are interpreted as shoreface deposits. Similarly, beds in bottomset position (FA 2) are interpreted as shoreface deposits, which overlie low-energy deposits of a restricted estuarine environment (FA 1). The foresets dip parallel with or only slightly oblique to a NESW trending string of crystalline elevations, indicating generally "alongshore" accretion of sand (i.e. not offshore accretion). Such palaeocurrent orientations suggest deposition of bars and dunes driven by diffracted longshore currents (Zecchin et al., 2010; Dietrich et al., 2017). Therefore, the studied succession of FA 2-5 is interpreted as fragments of a spit system or systems, which prograded generally into the Eggenburg Bay. The cross-beds with bottomsets and thickly preserved topsets indicate that large amounts of sediment were transported in suspension and that no, or only minor, erosion of the tops occurred.

A spit is a ridge or embankment of sediments attached to land at one end, with the other ending in open waters and is younger than the land to which it is attached. Spits are among the most dynamic features in coastal zones and are driven by complex formation and evolution processes. Their stability is the result of a fragile equilibrium between the availability of sediments and the forcing hydrodynamics (Petersen et al., 2008). The palaeogeography, especially local coastal morphology, relative sea level changes, wave and current, climate, sediment input and depositional rates are the principal factors controlling the spit thickness and geometry (Nielsen and Johannessen, 2009; Fruegard et al., 2020).

A spit system is mostly recognized as consisting of a spit platform and a spit. Bottomset, foreset and topset beds are typically within the system (Meistrell, 1972; Nielsen et al., 1988; Nielsen and Johannessen, 2009). The platform is a large-scale primary sedimentary body formed by sediment transport along the coast and rises above the sea floor but lies below mean low tide (Nielsen et al., 1988; Nielsen and Johannessen, 2009). Prograding clinoforms represent the most obvious part of the spit system. However, wave-built architectural elements of a spit system might also include swash and nearshore bars, berms, foreshores and backshores, beach ridges, washover channels and fans (Hine, 1979; Nielsen et al., 1988; Lindhorst et al., 2008; Fruergaard et al., 2020).

The deposits of FA 2 and FA 3 are interpreted as subaqueous spit platform (Nielsen et al., 1988). FA 2 represents in detail the spit bottomset. The bottomset consists of shoreface deposits, which are generally characteristic of spit systems (Nielsen et al., 1988; Nielsen and Johannessen, 2009). The studied FA 3 constitute foresets, i.e. the slipface of a spit platform, which are prone to erosion by storm waves and gravitational collapses (Nielsen et al., 1988). The recognized reactivation surfaces and undulated top within FA 3 can be explained by action of storms and avalanching, because storms tend to flatten the platform profile, whereas collapses steepen it by leaving head scarps (Nielsen et al.,1988; Zecchin et al., 2010). Spits with a steep slipface develop where the sediment is coarse-grained and the surrounding water is several metres deep, whereas the inclination of platform strata is lower in shallower water (Nielsen et al. 1988; Nielsen and Johannessen, 2009; Zecchin et al., 2010; Dietrich et al., 2017). The preservation of sigmoidal foresets in FA 3 indicates a relatively high sedimentation rate and available accommodation (e.g., Nielsen and Johannessen, 2008). The scale of the studied spits, based on the areal distance of studied outcrops points to $\sim 1 \mathrm{~km}$ width of the spit area ( $~ 500 \mathrm{~m}$ width of the single spit), which is well comparable with the data known from the Upper Pleistocene spits of the North Sea (Nielsen et al., 1988; Nielsen and Johannessen, 2009).

Sections oriented in generally in $\mathrm{N}-\mathrm{S}$ direction were studied in outcrops Maigen 2 and 3 . These sections are oriented parallel to oblique to foreset dip direction and reveal sigmoid foresets prograding in SW to SE direction. Both, the top and base of FA 3 (foreset) are broadly undulated and FA 3 reveals generally tabular shape on the distance of $\sim 75 \mathrm{~m}$ (outcrop Maigen 2).

Sections generally oriented in W-E direction were studied in the outcrops Maigen 1 and 3 and show bedding architecture transverse to the foreset dip direction. FA 3 reveals generally a tabular shape in these sections (followed on the distance of $\sim 80 \mathrm{~m}$ in outcrop Maigen 1; Fig. 9) and broadly undulated base and top. Moreover, a crude internal broadly convex-up concentric stratification (dome-like) was here followed. This dome is $\sim 5 \mathrm{~m}$ high and $>90 \mathrm{~m}$ wide. This stratification is interpreted as a record of spit system aggradation and is oriented generally perpendicular to its progradation. The generally lenticular sand bodies, separated by these aggrading surfaces, show a crude climbing trend generally towards the west. The thickness of the individual lenticular bodies/sets vary from several decimetres to almost 2 metres and their width was larger than the outcrop extent (i.e. $>90 \mathrm{~m}$ ). This depositional architecture reveals the orientation of the depression into which the foreset prograded (oblique toplap) generally from $\mathrm{N}$ or NE towards S or SW. The evidence of climbing of internal stratification could be a signal of a switching of the spit trajectory.

Very exceptional indications for backflow along the foresets are not explained as backsets filling slope chutes and connected with hydraulic jumps (Nemec, 1990) or evidence of cyclic steps (Lang and Winsemann, 2013), which typically occur on steep foresets of Gilbert-type deltas, but have been also recognized within spits (Zecchin et al., 2010). Reverse oriented shell-hash was in the studied case associated with low angle cross-stratified foresets only at the westernmost recognized edge of one spit in Maigen 1 (Fig. 4L). This particular outcrop is in the southernmost position of the spit system, in the catchment area of an assumed inlet into an estuary. In such circumstance, an enhanced effect of tidal currents is not excluded.

The spit is a sediment ridge on the spit platform and the platform is established in advance of the spit formation. The deposits of FA 4 are interpreted as a spit topset. The mechanisms responsible for the generation of the observed cross-stratification may be linked to both shore-parallel and shore-normal processes in a shallow-marine environment. In cases, when deposits of FA 4 directly covering the underlying foresets (FA 3), they are interpreted as an evidence of an oblique migration of sand dunes towards the front of the littoral bar, which favoured the avalanching of larger-scale inclined bedding/foreset. Similarly, according to Nielsen et al. (1988), the transition from the spit platform foresets to the topset is dominated by trough cross-bedded pebbly sand. The majority of the burrows of FA 4 extend downwards from the top surface of the dunes, indicating that the dunes were colonized by burrowing animals when they were relatively stationary during periods of calm conditions.

The presence of erosion surface with scattered granules along the contact of FA 3 and FA 4 indicates that the spit platform front was under erosion. Especially the edge of the platform is prone to erosion however, the erosional base might also be associated with the seaward migration of longshore troughs during progradation of the system (Hunter et al., 1979). Missing beach/foreshore deposits in the succession is explained by the palaeogeographic position inside the Eggenburg Bay (Fig. 17A, B). 

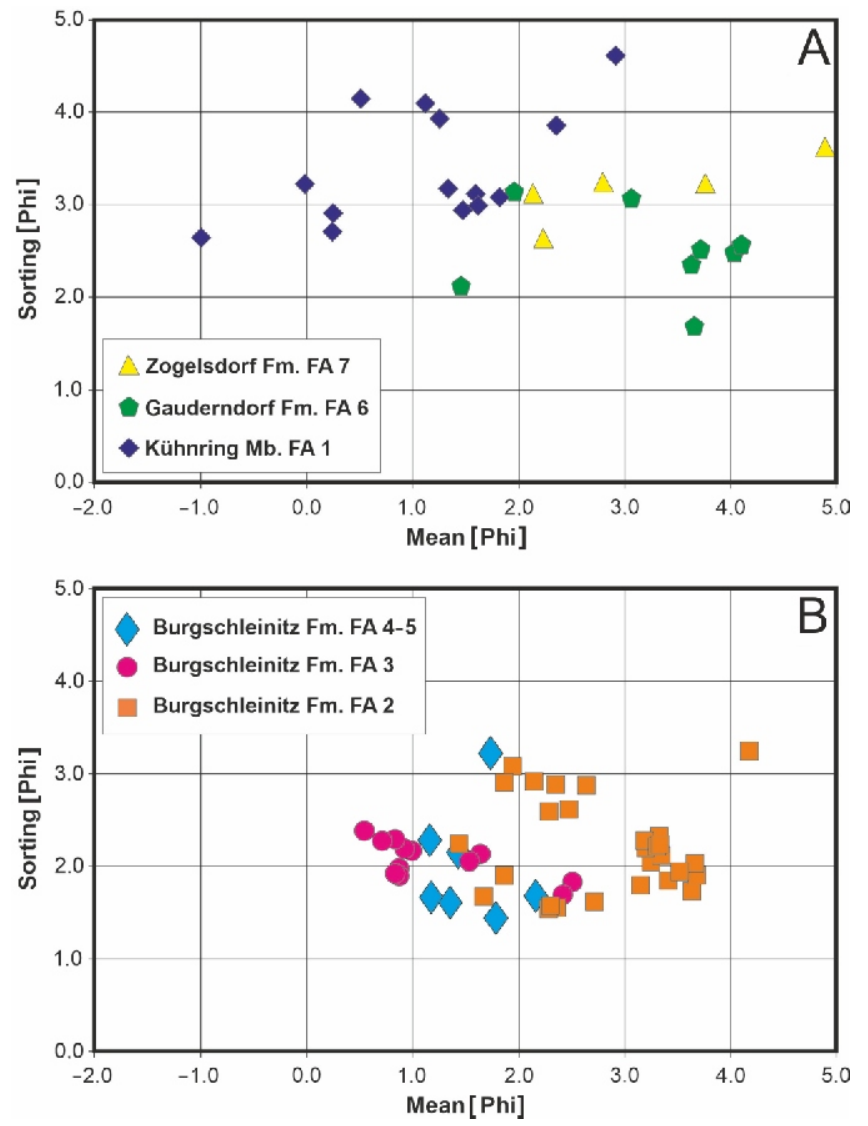

Fig. 11. Cross-plots of mean (average grain size) versus sorting (standard deviation) in $\Phi$-values for the studied samples

A - samples from Kühnring Member (FA 1), Gauderndorf Formation (FA 6) and Zogelsdorf Formation (FA 7); B - samples from fine-grained FA 2 and coarse-grained FA 3 and FA 4-Fa 5 of the Burgschleinitz Formation

The undulated relief of the surface between topset and foreset with a relief of up to one metre (clearly seen in sections parallel to foreset dip direction; Fig. 7) is in case of the spit system interpreted to represent changes between progradational and aggradational phases of platform construction (Nielsen et al., 1988).

The upward alternation of lower shoreface sandstones (FA 5) and upper shoreface sandstones (FA 4) within the spit topset indicates regressive or transgressive settings due to relative sea level changes. These variations are supposed to be a consequence of spit system progradation or retrogradation.

\section{GRAIN SIZE AND PROVENANCE STUDY}

Grain size data are mainly characterizing the energy of the deposition medium (Reineck and Singh, 1980), changing during sedimentation of the different formations and provide comparable mathematical data of mean grain size, sorting and skewness.

Results of the provenance analyses are based on combination of evaluation of light and heavy mineral studies. Provenance study provides data about the source area, which might be especially important in case of the prograding clinoforms and evaluation of longshore drift typical for coastal spits. Prove-
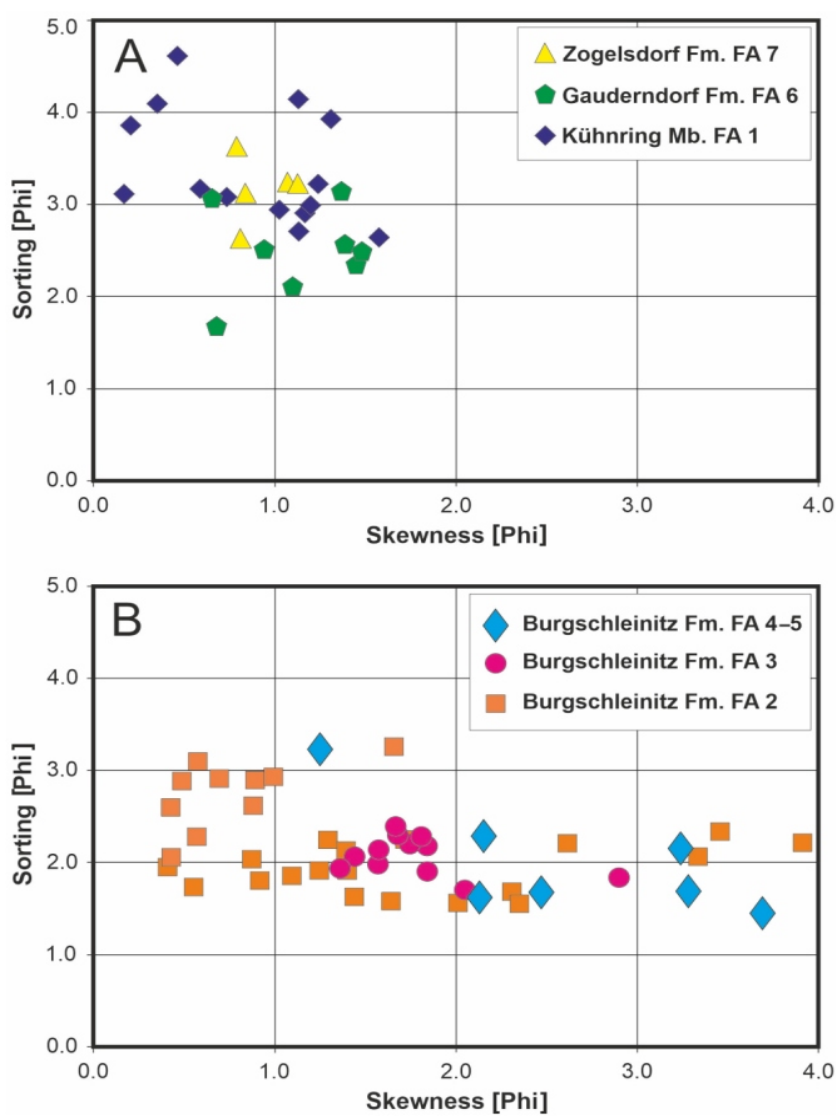

Fig. 12. Cross-plots of skewness (symmetry) versus sorting (standard deviation) of the grain size in $\Phi$-values for the studied samples

A - samples from Kühnring Member (FA 1), Gauderndorf Formation (FA 6) and Zogelsdorf Formation (FA 7); B - samples from fine-grained FA 2 and coarse-grained FA 3 and FA 4-Fa 5 of the Burgschleinitz Formation

nance results further support the palaeocurrrent patterns, palaeogeography or even the sequence stratigraphic interpretations (Dinis et al., 2016; Nehyba, 2018). Such a comparison might attest the orientation of the prograding clinoform in relation to the coast (i.e. parallel or perpendicular to the shore).

\section{GRAIN SIZE DISTRIBUTION}

Grain size data from the Kühnring Member (FA 1; Appendix $\left.1^{*}\right)$ are apparent by their high proportion of gravel $(17-60 \%$; avg $32.7 \%$ ) and high amount of sand (30-66\%; avg 48.6\%) with similar proportions in the coarse, medium and fine sand fractions. They show a considerably smaller content of silt (5-31\%; avg $15.4 \%$ ) and low clay (0.7-4.4\%, in exception $14.3 \%$; avg $3.3 \%$ ). This results in an avg grain size (mean) of -1.0 to $2.9 \Phi$ and a quite high standard deviation (sorting) of 2.6-4.6, reflecting very poor to extremely poor sorting (Fig. 11A; Friedman, 1962). Due to these high portions of coarse material, the skewness is between $0.2-1.6$ and the sediments are positive to strongly positive coarse skewed (Fig. 12A). Accordingly, the sediments are widely dispersed in the ternary diagram, mainly classified as silty gravel sands, gravel sands, or silty-gravelly sands (Fig. 13A). 

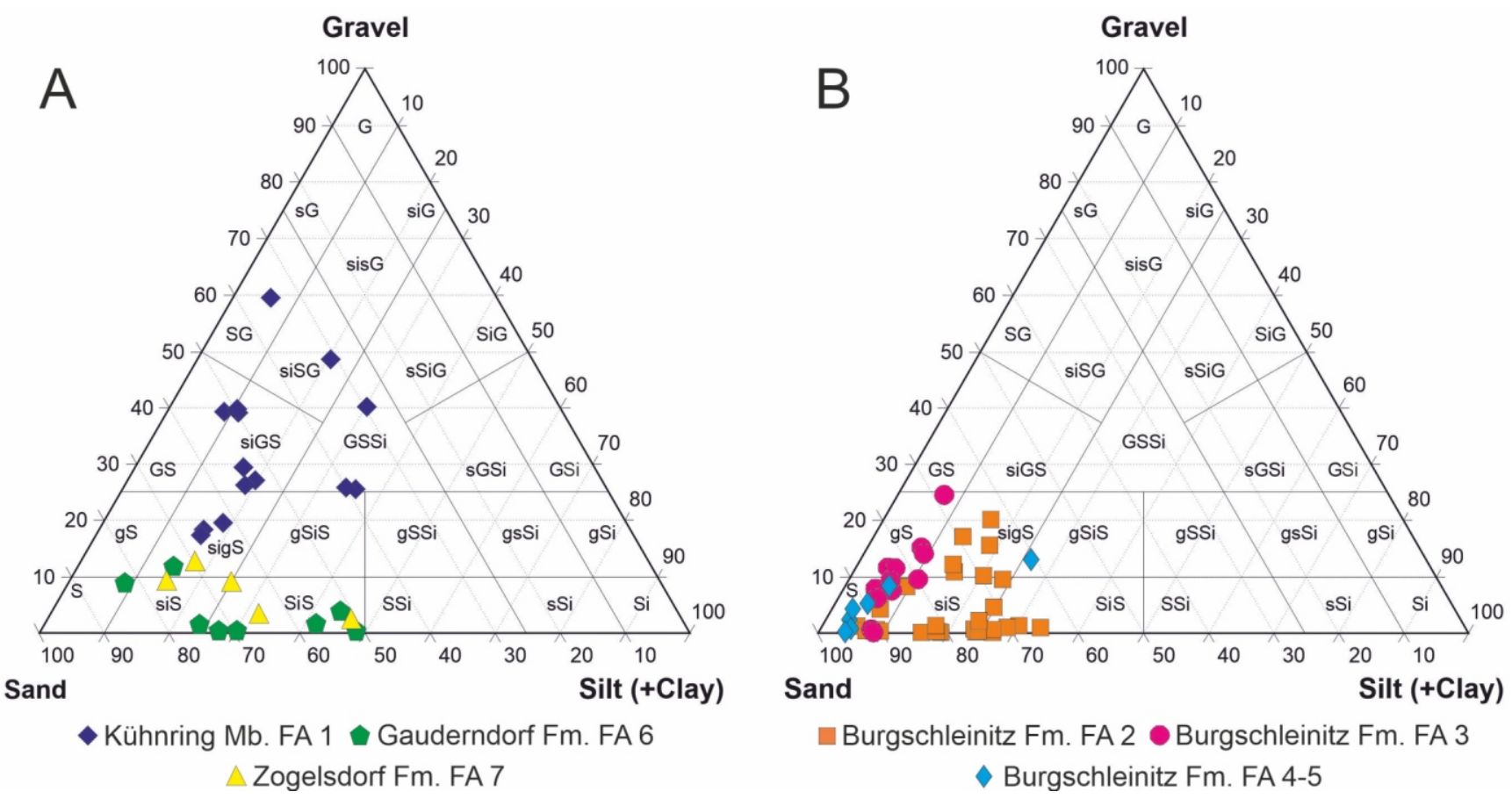

Burgschleinitz Fm. FA 2 Burgschleinitz Fm. FA 3

$\checkmark$ Burgschleinitz Fm. FA 4-5

Fig. 13. Results of grain size analysis in the ternary diagram gravel-sand-silt (+clay)

\begin{abstract}
A - samples from Kühnring Member, Gauderndorf Formation and Zogelsdorf Formation; B - samples from fine-grained FA 2 and coarse-grained FA 3 and FA 4-Fa 5 of the Burgschleinitz Formation; nomenclature in the ternary diagram after Füchtbauer (1959) and Müller (1961); G - gravel, S - sand, Si - silt, g - gravelly, s - sandy, si - silty
\end{abstract}

Samples of the Burgschleinitz Formation are grouped in FA 2, FA 3 and FA 4-FA 5 (Appendix 1). FA 2 forms the lower part in the Wagerer (Maigen 1) and Stranzl (Maigen 2) sandpits (Figs. 3 and 5; Appendix 1). The samples from the Wagerer sandpit have quite low portions of gravel $(0.05-8.2 \%$; avg $1.5 \%)$ whereas in the Stranzl sandpit the portion of gravel is frequently considerably higher $(9.8-20.1 \%$, rarely $0.3-2.1 \%$; avg $8.4 \%$ ). The percentages of sand and clay are in both outcrops quite similar (sand: $63-94 \%$; avg $77.5 \%$, clay: 0.8-11.5\%; avg 2.5\%). In contrast, the proportions of silt in these sediments are in the Wagerer sandpit somewhat higher (4.2-32\%; avg 16.6\%) as in the Stranzl sandpit (7-22\%; avg 14.4\%). This means, that in the Wagerer sandpit in the lower part silty fine-grained sands and siltsands prevail, coarsening upward to medium-fine-grained sands respectively medium-coarse-grained sands. In contrast, in the Stranzl sandpit silty-gravelly sands dominate beside silty sands (Fig. 13B). Therefore, the avg grain size (mean) of the sediments of FA 2 in the Burgschleinitz Formation is 1.4-4.2 $\Phi$. Values of 1.6-3.3 of the standard deviation (sorting) mirror poor to very poor sorting of the sediments too (Fig. 11B). The positive to strongly positive skewness (symmetry) between $0.4-3.9$ shows the dominance of the coarse part in grain sizes (Fig. 12B).

Coarse sediments form the upper part of the Burgschleinitz Formation in all outcrops (FA 3, FA 4-FA 5; Figs. 3, 5 and 6). They usually show low portions of gravel $(0.2-15 \%$, rarely higher up to $25 \%$ ) and are dominated by the sand fraction (61-96\%; avg 85\%). This results in quite low proportions of silt and clay (silt: $2.1-9.3 \%$, rarely up to $22.5 \%$; avg $6.0 \%$; clay: $0.5-3.4 \%$; avg $1.2 \%$ ). Sediments are therefore mainly coarseor medium- to fine-grained sands as well as gravelly coarse-grained sands (Fig. 13B). Compared to the lower sediments of the Burgschleinitz Formation is the avg grain size (mean) of the coarse sediments obviously in the coarser frac- tion, making up $0.5-2.5 \Phi$. Sorting is again poor to very poor, resulting in standard deviation values from 1.4 to 3.2 , similar to the lower sediments (Fig. 11B). The skewness is with values of 1.3-3.7 again strongly positive (Fig. 12B).

In the above following Gauderndorf Formation (FA 6) the basal part is striking coarser than the rest of the sediments (Appendix 1). They show higher portions of sand (73-83\%) and gravel $(9-12 \%)$, whereas proportions of silt $(8-10 \%)$ and clay $(1-4.6 \%)$ are low. Coarse, medium and fine sand are roughly evenly distributed. Therefore, the avg grain size (mean) is 1.5 to $2.0 \Phi$ (Fig. 11A). In contrast, the majority of the Gauderndorf Formation upsection is significantly finer grained. These sediments are characterized by a low gravel portion $(0.3-4.1 \%$; avg $1.4 \%$ ) and a moderate sandy portion (51-75\%; avg 62.8\%), mainly dominated by the fine sand fraction. On the other hand, is the content of silt quite high (19-43\%; avg 31.3\%) but the clay content low (1-7\%; avg 4.4\%). The sediments are mainly siltsands or silty sands (Fig. 13A). The avg grain size (mean) is 3.1-4.1 $\Phi$ and the standard deviation, according to the poor to very poor sorting, is 1.7-3.1 (Fig. 11A). The predominance of the coarser part in grain sizes reflect a positive to strongly positive skewness between 0.7-1.5 (Fig. 12A).

The grain size distribution of the topmost Zogelsdorf Formation (FA 7; Appendix 1) is widely similar to the Gauderndorf Formation. In detail the sediments differ in a slightly higher content in the gravel size (2.5-13\%; avg 7.5\%), which are biogenic components as well as fine gravel. They are also slightly coarser in the coarse and medium grain size of the sandy fraction (51-76\%; avg 65.5\%). In contrary, compared to the Gauderndorf Formation, the silty fraction in the Zogelsdorf Formation is significantly lower (12-32\%; avg $20.1 \%$ ), whereas the clay content is quite similar (4-15\%; avg 6.9\%). The sediments are silty sands, silty-gravelly sands or siltsands (Fig. 13A). The 

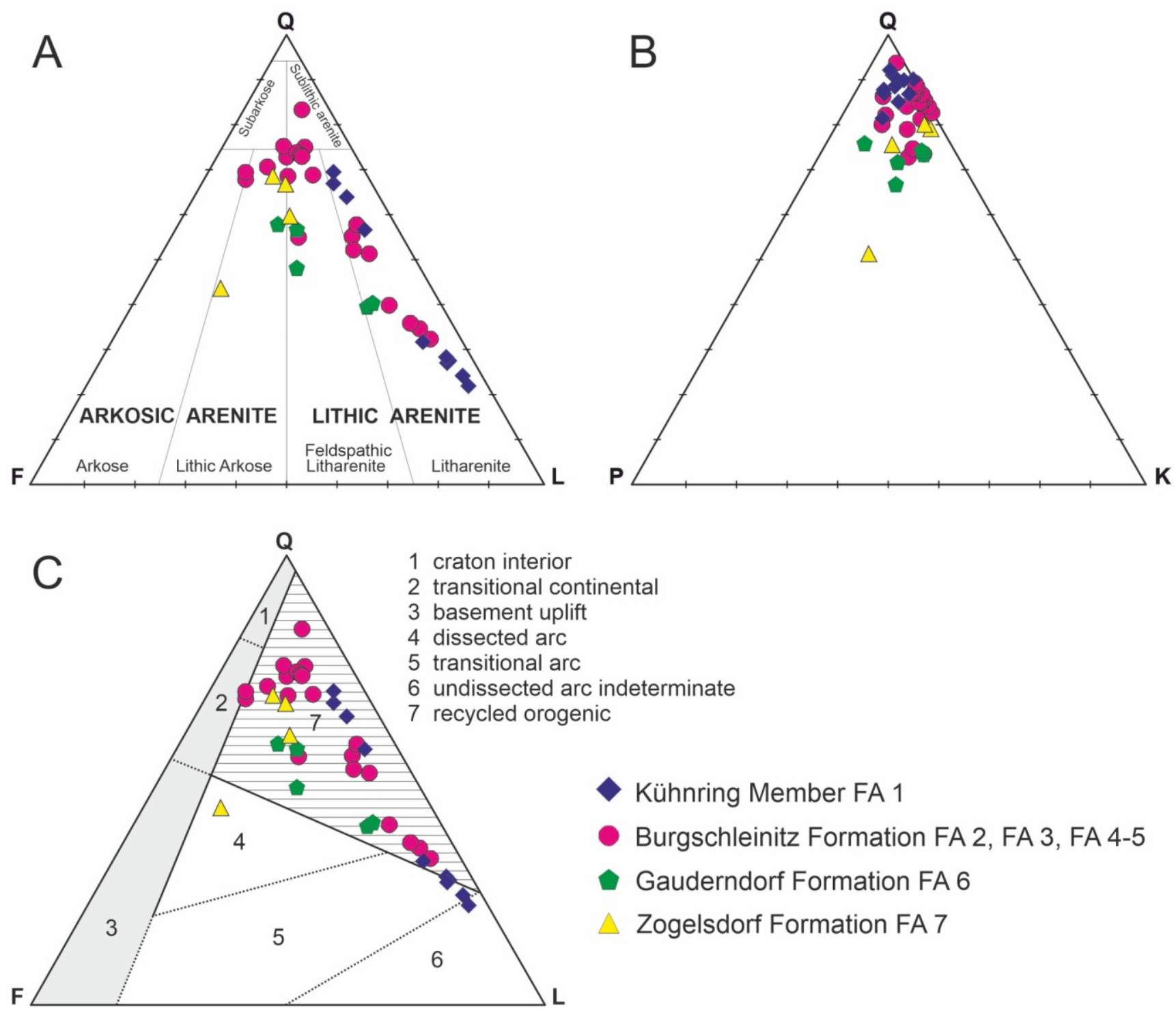

Fig. 14. Discrimination ternary diagrams of petrography of light minerals for the studied samples

A - Q-F-L classification diagram after Folk (1968) and Okada (1971) for the studied samples; B - QPK diagram (Girty et al., 2003) for the studied samples; C - QFL discrimination diagram for the studied samples (Dickinson, 1985); Q - total quartz, F - total feldspar (plagioclase + alkali feldspar), $\mathrm{P}$ - plagioclase, $\mathrm{K}$ - alkali feldspar, L - total lithic components

avg grain size (mean) is $2.1-4.9 \Phi$ the sorting is very poor (standard deviation 2.6-3.6) and the skewness is positive to strongly positive (0.8-1.1; Figs. 11A and 12A).

Thus, the deposits of the Burgschleinitz Formation are in general better sorted and reveal more stronger positive skewness than the deposits of the Kühnring Member, Gauderndorf and Zogelsdorf Formations. The foreset beds (FA 3) provide quite uniform results of sorting and skewness. Results for the bottomset (FA 2) on the other hand, disclose the highest variation in the mean grain size, skewness and also in the sorting within the spit deposits. Foreset (FA 3) and topset deposits $(\mathrm{FA} 4,5)$ reveal a similar mean grain size.

\section{PETROGRAPHY OF LIGHT MINERALS}

The studied samples can be mostly classified as lithic arenites $(72.5 \%)$, significantly less common as arkosic arenites $(20 \%)$ and exceptionally sublithic arenites $(5.0 \%)$ or subarkoses $(2.5 \%)$ (sensu Pettijohn et al., 1987). The classification diagram of Folk (1968) and Okada (1971) for studied samples is presented in Figure 14A. The samples from the Burgschleinitz Formation are mineralogically the most mature. They have generally a higher content of quartz (avg 61.2\%) and also of feldspar (avg 11.9\%) compared to those from the Kühnring Member (content of quartz avg 41.8\%, content of feldspar avg 5.2\%). A lower content of quartz and significantly higher content of feldspar is observed also in samples from the Gauderndorf Formation (quartz avg 48.4\%, feldspar avg $18.8 \%$ ) and Zogelsdorf Formation (quartz avg $59.7 \%$, feldspar avg 24\%). Alkali feldspar always dominate over plagioclase. The highest content of plagioclase was recognized in samples from the Gauderndorf Formation (avg 6.9\%) and the Zogelsdorf Formation (avg 4.7\%). An increasing maturity for the Burgschleinitz Formation, especially if compared to overlying deposits of the Gauderndorf Formation and Zogelsdorf Formation, is also visible from QPK diagram (Fig. 14B; Girty et al., 2003) and is associated with increased feldspar weathering.

On the Q-F-L (Fig. 14C) discrimination diagram the majority of samples of the sedimentary succession occupy the recycled orogenic field with a relation to continental/craton source. Such 

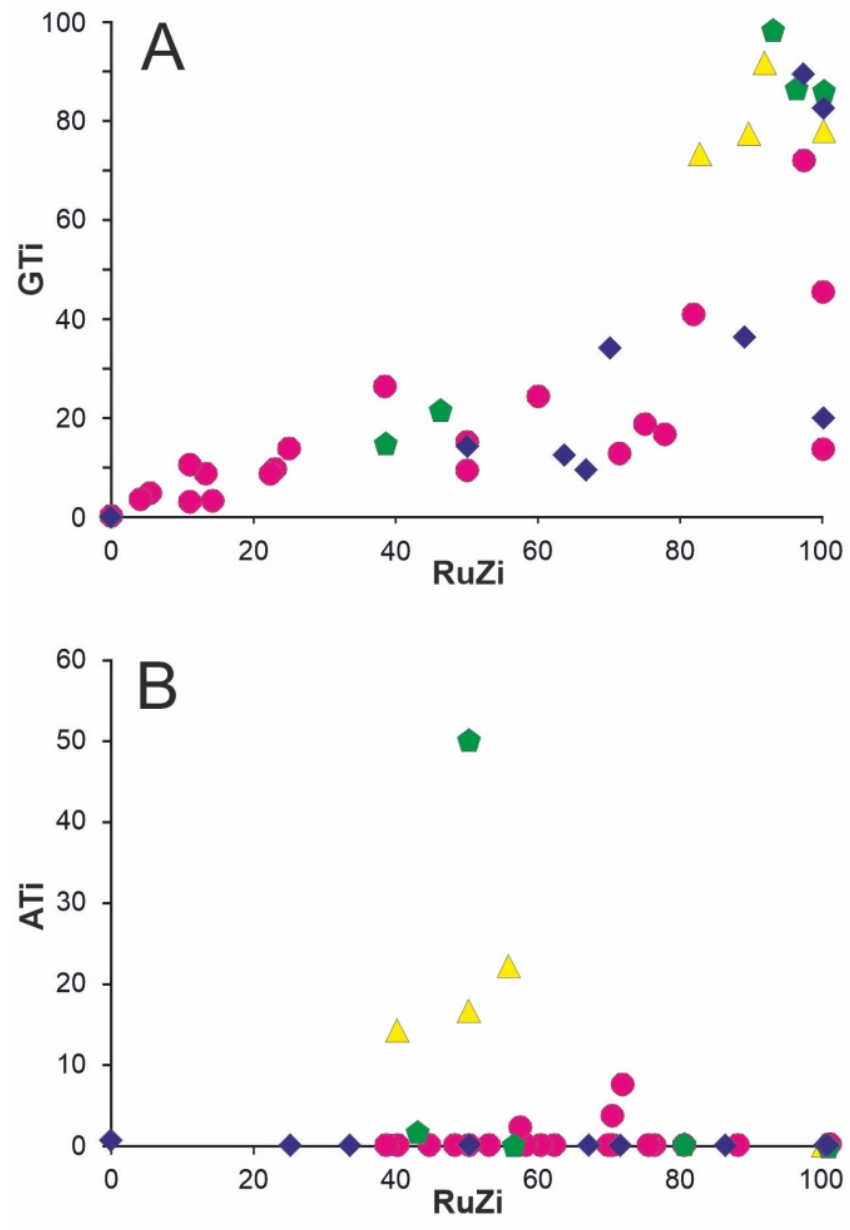

Kühnring Mb. Burgschleinitz Fm.

Gauderndorf Fm. $\triangle$ Zogelsdorf Fm.

\section{Fig. 15. Heavy minerals cross-plots}

A - index GTi vs. RuZi; B - index ATi vs. RuZi (indexes after Morton and Hallsworth, 1999); ATi (100 x apatite count/total apatite plus tourmaline), GTi (100 x garnet count/total garnet plus tourmaline), RuZi (100 x rutile count/total rutile plus zircon)

a distribution reflects complex sources of the most cratonward part of the distal Alpine-Carpathian Foredeep Basin, when the source from crystalline metamorphic rocks is combined with the source from granites. All these rocks occur along the eastern margin of the Bohemian Massif. Although all the samples reveal generally the common source, it is clear, that results from the studied sedimentary succession show some trends (similarly in Fig. 14A-C). Samples of the Kühnring Member and Burgschleinitz Formation are oriented almost parallel to the Q-L axes and represent the first close related group (i.e. the first sedimentary cycle). An increased proportion of mature material is evident for the Burgschleinitz Formation. We can assume that a large part of the sediments of the Burgschleinitz Formation, as well as that of the Kühnring Member, consists of redeposited material.

The samples from the Gauderndorf Formation and Zogelsdorf Formation form the second common group and show the input of relatively fresh material from the basin margin sources into the basin respectively the next sedimentary cycle (in case of the Zogelsdorf Formation).
HEAVY MINERALS

Heavy minerals are sensitive indicators of provenance, weathering, transport, deposition and diagenesis (Morton and Hallsworth, 1994). Heavy mineral assemblages, the ratios ATi (100 $\times$ apatite count/total apatite plus tourmaline), GZi (100 $\times$ garnet count/total garnet plus zircon), RuZi $(100 \times$ rutile count/total rutile plus zircon), GTi (100 × garnet count/total garnet plus tourmaline) (see Morton and Hallsworth, 1999) and the ZTR index (total zircon plus tourmaline plus rutile) have been evaluated. The GTi, GZi, ATi and RuZi mineral ratios (according to Morton and Hallsworth, 1994) were used to reflect the source rocks characteristics (because they are comparatively immune to alteration during the sedimentary cycle), to indicate successive stages in provenance evolution, the tectonic history and as indicators for sediment transport paths. The ZTR index is widely accepted as a criterion for the mineralogical "maturity" of heavy mineral assemblages (Hubert, 1962; Morton and Hallsworth, 1994) in case of derivation from a similar source. The proportion of opaque versus translucent minerals (OP/TR) was counted to get further information concerning weathering and reworking conditions (Table 2B).

Heavy mineral assemblages partly differ within the sedimentary succession (see Table 2A), however, both the dominance of staurolite in the heavy mineral spectra and prevalence of tourmaline within the very stable heavy minerals are typical for the whole succession. A relative significant increase in the content of garnet and also staurolite is evident for the Gauderndorf Formation and Zogelsdorf Formation.

Cross-plots comparing GTi vs. RuZi and ATi vs. RuZi are presented in Figure 15 and show some grouping of samples of the studied formations. The values of these ratios are presented in Table 2B.

The results show variable amounts of opaque, ultrastable (zircon, tourmaline and rutile), stable (staurolite, garnet, apatite, titanite) and moderately stable (epidote, sillimanite, kyanite and andalusite) minerals. Occurrences of unstable minerals (hornblende, pyroxene, sphene, spinel) were extremely rare. Table 2A and Figure 16B show, that stable minerals are the most dominant in deposits of the Zogelsdorf Formation. A more complex situation can be followed for the deposits of the other three remaining formations (Fig. 16A). However, an increase in the content of stable heavy minerals is evident for the Gauderndorf Formation and Zogelsdorf Formation.

Interpretation: The heavy mineral spectra point in general to a principal input of metamorphic rocks (both middlegrade/especially metapelites and high-grade/granulites, gneisses) from the source area with an influence of granites in provenance. Redeposition of material from older deposits must be also taken into account especially for the Burgschleinitz Formation. Similar OP/TR ratio within the whole succession points to relatively stable weathering and reworking conditions (Table 2B). Therefore, the variations in the heavy mineral spectra reflect the variation in the configuration of the source area. Almost similar values of RuZi for all four formations (Table $2 \mathrm{~B}$ ) confirm both the presence of recycled and the supply of fresh material. The primary source can be located in the nearby crystalline geological units of i.e. Moravian and Moldanubian Superunits and Thaya Batholith. However, the impact of these primary sources and redeposition vary within the sedimentary succession and so two groups of samples can be recognized. The first one is represented by deposits of the Kühnring Member and the Burgschleinitz Formation, the second one by the overlying deposits of the Gauderndorf Formation and Zogelsdorf Formation. 
Heavy mineral data (median) of the Kühnring Member, Burgschleinitz Formation, Gauderndorf Formation and Zogelsdorf Formation

\begin{tabular}{|l|c|c|c|c|c|c|c|c|}
\hline $\begin{array}{c}\text { Formation/ } \\
\text { heavy mineral }\end{array}$ & \multicolumn{2}{|c|}{$\begin{array}{c}\text { Kühnring Mb. } \\
\text { median [\%] (min.-max.) }\end{array}$} & \multicolumn{2}{c|}{$\begin{array}{c}\text { Burgschleinitz Fm. } \\
\text { median [\%] }\end{array}$} & \multicolumn{2}{c|}{$\begin{array}{c}\text { Gauderndorf Fm. } \\
\text { median [\%] (min.-max.) }\end{array}$} & \multicolumn{2}{|c|}{$\begin{array}{c}\text { Zogelsdorf Fm. } \\
\text { median [\%] }\end{array}$ (min.-max.) } \\
\hline Zircon & 2.1 & $(0-6)$ & 6.6 & $(0-17)$ & 3.6 & $(0-8)$ & 2.3 & $(0-4)$ \\
\hline Rutile & 4.1 & $(0-14)$ & 10.6 & $(0-17)$ & 4.4 & $(01-9)$ & 3.3 & $(2-5)$ \\
\hline Titanite & 0.8 & $(0-5)$ & 0.4 & $(0-2)$ & & - & 0.2 & $(0-0.5)$ \\
\hline Tourmaline & 27.3 & $(2-89.6)$ & 23.5 & $(7-38)$ & 12.3 & $(0.5-31)$ & 5.3 & $(3-7)$ \\
\hline Garnet & 7.7 & $(0-19)$ & 4.2 & $(0-18)$ & 12.3 & $(0.5-31)$ & 22.5 & $(17-33)$ \\
\hline Staurolite & 43.6 & $(4-78)$ & 26.7 & $(6-70)$ & 41 & $(10-60)$ & 57.5 & $(46-67)$ \\
\hline Kyanite & 12.8 & $(0.5-65)$ & 16.0 & $(2-29)$ & 16.4 & $(10-32)$ & 6.8 & $(4-11)$ \\
\hline Sillimanite & 1.7 & $(0-7)$ & 8.5 & $(0-22)$ & 5.0 & $(2-10)$ & 1.1 & $(0.5-2)$ \\
\hline Andalusite & 0.2 & $(0-0.5)$ & 1.9 & $(0-7)$ & 0.3 & $(0-1)$ & 0.1 & $(0-5)$ \\
\hline Apatite & 0.1 & $(0-0.5)$ & 0.1 & $(0-1)$ & 0.2 & $(0-0.5)$ & 0.9 & $(0-2)$ \\
\hline Epidote+Zoisite & 0.2 & $(0-1)$ & & - & 0.8 & $(0-2)$ & 0.3 & $(0-0.5)$ \\
\hline
\end{tabular}

Values of heavy mineral data of ZTR (total zircon plus tourmaline plus rutile), ATi (100 $\times$ apatite count/total apatite plus tourmaline), GZi (100 $\times$ garnet count/total garnet plus zircon), RuZi (100 $\times$ rutile count/total rutile plus zircon) and OPITR (proportion of opaque versus translucent minerals)

\begin{tabular}{|l|c|c|c|c|c|c|c|c|}
\hline \multirow{2}{*}{$\begin{array}{c}\text { Formation/ } \\
\text { heavy mineral ratio }\end{array}$} & \multicolumn{2}{|c|}{ Kühnring Mb. } & \multicolumn{2}{c|}{ Burgschleinitz Fm. } & \multicolumn{2}{c|}{ Gauderndorf Fm. } & \multicolumn{2}{c|}{ Zogelsdorf Fm. } \\
\cline { 2 - 9 } & median [\%] (min.- max.) & \multicolumn{2}{c|}{ median [\%] } & (min.- max.) & \multicolumn{2}{c|}{ median [\%] (min.- max.) } & \multicolumn{2}{c|}{ median [\%] (min.- max.) } \\
\hline ZTR & 33.4 & $3.5-93.0$ & 40.8 & $8-56$ & 20.3 & $4-45$ & 10.75 & $8-16$ \\
\hline ATi & 0.06 & $0-0.56$ & 0.5 & $0-6.7$ & 10.32 & $0-50$ & 13.96 & $0-22.2$ \\
\hline GZi & 70.7 & $0-100$ & 39.29 & $0-100$ & 74.7 & $38.5-100$ & 90.9 & $82.6-100$ \\
\hline RuZi & 62.9 & $0-100$ & 62.7 & $33.3-100$ & 65.8 & $42.9-100$ & 61.4 & $40-100$ \\
\hline OP/TR & 1.6 & $0.5-4.3$ & 1.1 & $0.3-4.9$ & 1.2 & $0.1-4.9$ & 1.1 & $0.1-4.9$ \\
\hline
\end{tabular}

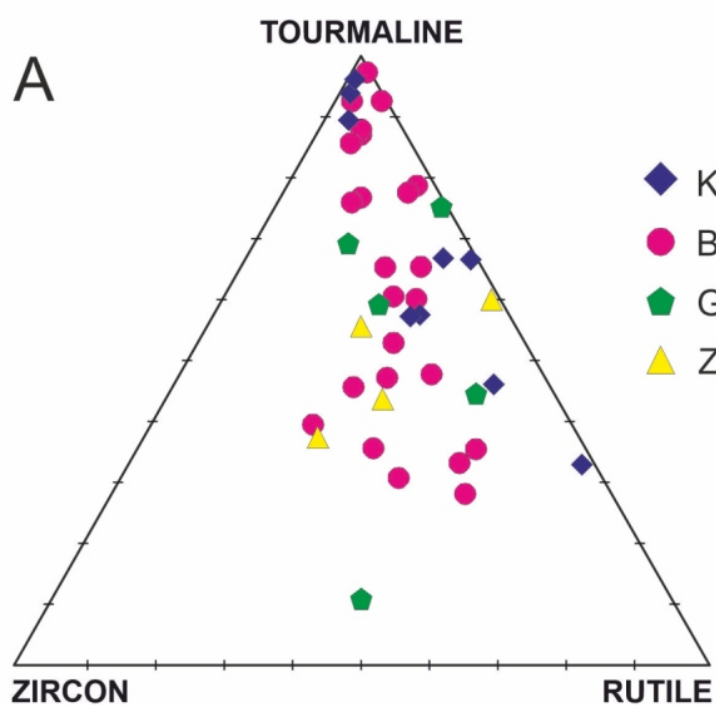

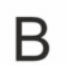

Kühnring Member

Burgschleinitz Formation

Gauderndorf Formation

Zogelsdorf Formation

Fig. 16. Heavy mineral ternary diagrams

A - ternary diagram of the ultrastable heavy minerals zircon, tourmaline and rutile; B - ternary diagram of stable (staurolite, garnet, apatite, titanite) - moderately stable (epidote, sillimanite, kyanite, andalusite) - ultrastable (zircon, tourmaline, rutile) heavy minerals 

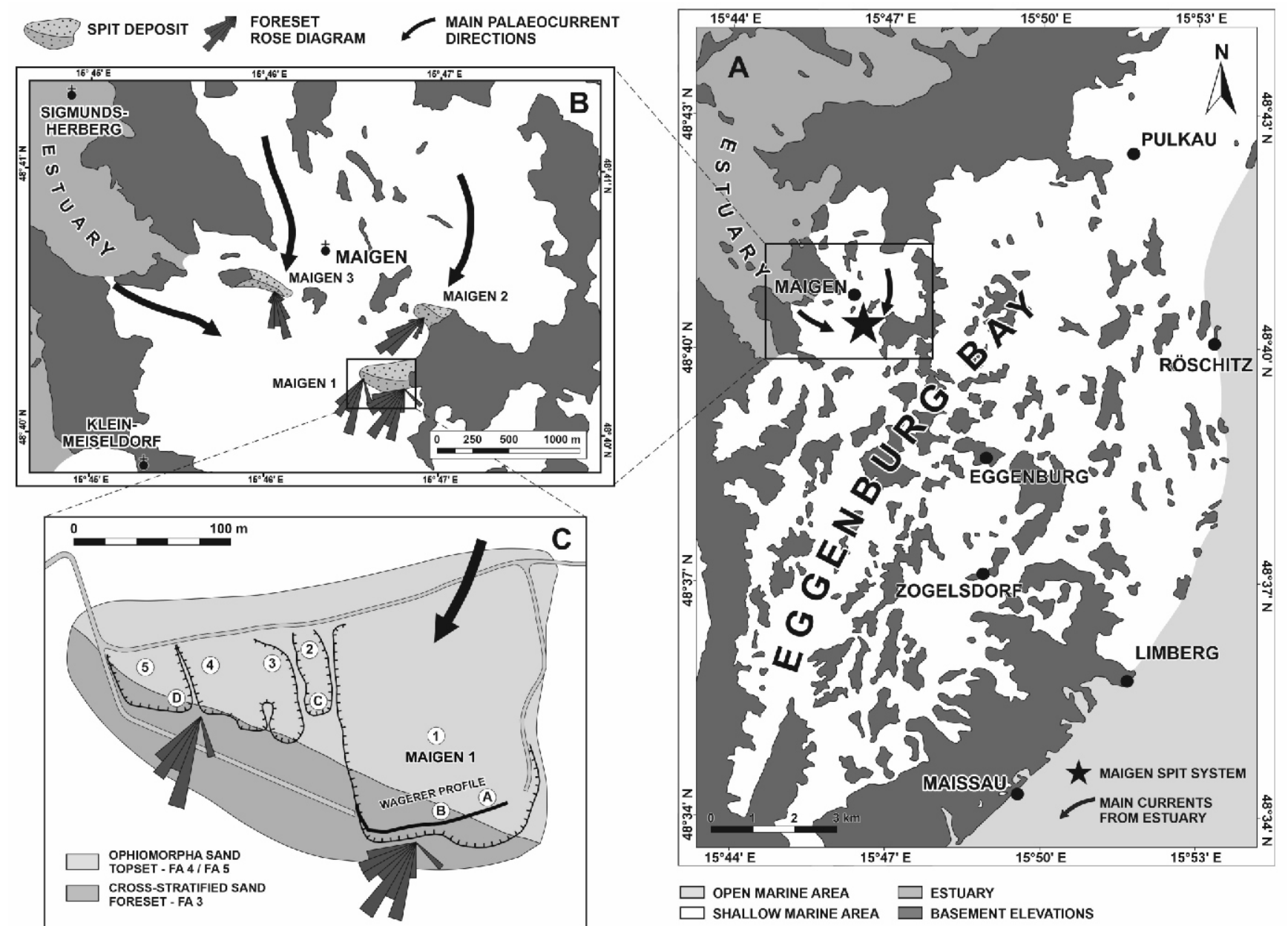

Fig. 17A - palaeogeographic sketch of the Eggenburg Bay in the Early Miocene (Eggenburgian) with distribution of basement elevations of islands, peninsulas and shoals, reconstructed from geological mapping. Between Pulkau and Limberg a $\mathrm{N}-\mathrm{S}$ trending string of crystalline islands is separating the Eggenburg Bay to the open sea in the east. North-west of Maigen an estuary is developed; B - detail sketch of the Maigen area with reconstructed position of spits between basement elevations and the estuary in the north-west; C - detail sketch of the Wagerer sandpit (Maigen 1) and adjacent outcrops with distribution of facies associations FA 3 (cross-stratified sand) and FA 4, 5 (Ophiomorpha sand), for legend to numbers and letters refer to Figure 1B

The GZi and GTi indexes clearly show an increase of garnet in the Gauderndorf Formation and Zogelsdorf Formation compared to the Kühnring Member and Burgschleinitz Formation. This is also connected with the increase of staurolite and reduction of tourmaline (partly also of other superstable minerals). These observations are interpreted as a signal of higher input of fresh derived material from mica-schist and an enlargement of the source area (a new depositional cycle). Whereas the ATi index reveals an increase in the Gauderndorf Formation and Zogelsdorf Formation compared to the Kühnring Member and Burgschleinitz Formation, the results for ZTR are directly opposite. The highest amounts of recycled material (i.e. a higher ZTR index) are therefore expected for the deposits of the Burgschleinitz Formation at the Maigen site, which are interpreted as a result of recycling and the influence of longshore currents. Significant variations in the indexes within deposits of the same formation might be connected with variations in the transport distances or energy of the environment (commonly high in foreshore and shoreface areas). Because transport distances were relatively short, sediment storage and recycling might have played also an important role. Fluctuating heavy mineral assemblages/indexes are supposed to have been derived directly from alluvial/fluvial input transporting the weathered material into the nearshore environment. Indexes with more homogeneous/average results are inferred to be fed by sediments that originally accumulated on nearshore environments or were recycled. One can speculate about a principal role of nearby local sources for the Kühnring Member and Burgschleinitz Formation, combined with a high importance of later reworking and recycling for the Burgschleinitz Formation (with redeposition also from the Kühnring Member). The older deposits were redeposited and mixed with fresh material eroded from the primary sources. We suppose availability of large volumes of sand derived from deeply weathered crystalline basement subjected to erosion (and uplift?) in the up drift source area. The primary material was probably intensely weathered (source area, alluvial storage, subaerial unconformities; see Morton and Hallsworth, 1994). New depositional cycles, represented by the Gauderndorf Formation and Zogelsdorf Formation, reveal a broader source area with a high amount of fresh weathered input. 


\section{DISCUSSION}

A palaeogeographic sketch of the Eggenburg Bay in the Early Miocene (Eggenburgian) and the spit evolution in the area under study is presented in Figure 17A and B. At first, morphological depressions on the deeply weathered crystalline basement were partly filled with mainly immature sediments derived from the primary sources. These depressions were firstly flooded by the transgressing Paratethys Sea, which is recorded by the deposits of the Kühnring Member (FA 1). Due to a continuing relative sea level rise and the ingressing of the sea in a morphologically highly structured crystalline area of the Bohemian Massif, numerous small islands, peninsulas and bays occurred (Pervesler et al., 2011). Crystalline elevations formed tectonically induced strings and groups of small shoals and islets. The described spit system developed close to one of such groups of elevations nearby the mouth of an estuary. From the studied outcrops a large, generally W-E trending spit system or systems can be deduced, which was anchored at roughly NE-SW trending bedrock ridges (Fig. 17B).

The development of the clinoforms started at a topographic basement step (Zecchin et al., 2010). The spit system inception started when the depositional depth, as function from basement morphology, increased dramatically and the transported material prograded into a relatively deeper (i.e. several metres deep - still within the shoreface) setting. Although the studied spit system/systems prograded into deeper water on an inclined sea floor, the amount of sand supplied to the spit platform was available to maintain balance with increasing accommodation space, which is confined by the deposition and preservation of relatively thick and large successions. Material was delivered mostly by longshore drift and partially also from the islets. At foresets avalanching occurred due to sediment accumulation by gravity-flow processes, while on topsets medium- to large-scale dunes migrated. The growth of the spit systems was facilitated by dominating SW to SSE directed currents favoured by strong currents from the inlet of an estuary in the north-west (Fig. 17A, B). This was causing significant erosion and a more or less continuous longshore i.e. generally SW-ward directed littoral drift along the studied segment in the Eggenburg Bay. Quite constant foreset dip directions and very rare indications of current reversals or sedimentation pauses indicate a relative stability in transport direction and periods of stable depositional conditions characterized by strong unidirectional currents, high sand supply and sufficient accommodation space (Nielsen and Johannessen, 2009). Similarly, preserved topsets indicate high sediment supply and a sufficient accommodation space. Small variations in foreset dip direction probably reflect changes in the curvature of the spit.

Spit sedimentation is mainly controlled by wave-induced currents resulting in longshore and cross-shore sediment transport. These processes induce downdrift and seaward spit progradation. Wave-induced longshore currents are supposed to have been the dominant and primary responsible agent for the formation of the studied spits. However, some locally areal variations in the origin of these currents cannot be excluded as revealed by the situation at the westernmost recognized spit (outcrop Maigen 3). Low-angle, tangential, S- and SE-ward inclined foresets, recorded here at the distal part of the spit, indicate sediment transport roughly from $\mathrm{N}$ to NW, whereas in the other outcrops transport from $N$ to $N E$ is inferred from the foreset inclination. This variation in the direction of spit progradation might be partly influenced by the curvatures of the spits or complicated flow patterns at the inlet of an estuary combined with complex coastal morphology. However, the outcrop Maigen 3 is close to the margins of the Eggenburg Bay, where an inlet to an estuary is inferred (Fig. 17A, B). Strong currents induced within the entry to the estuary might be responsible for the shift in the current direction and these currents might be driven by tidal or meteorological changes. Similarly, the only evidence of backflow along the foresets was noted in the westernmost outcrop west of the Maigen 1 sandpit (Figs. 4L and 17C). An enhanced role of tidal current is not excluded in the estuary inlet as a small tidal range generally favours the formation of spit systems (Nielsen and Johannessen, 2009). Several studies investigated the sedimentary evolution of microtidal, mesotidal, macrotidal and hypertidal barrier spits (Hine, 1979; Fitzgerald et al., 1984; Nielsen et al., 1988; Allard et al., 2008; Lindhorst et al., 2008, 2010; Nielsen and Johannessen, 2009; Fruergaard et al., 2015a, 2020). Maybe due to different current regimes in the inlet of the estuary spit formed in case of Maigen 1 and 2 on the cratonward margin of the islets, while in Maigen 3 it developed on the basinward side (Fig. 17B).

The occurrence of relatively coarse-grained topsets (FA 4) directly above foreset beds (FA 3) with generally similar grain size is connected with high sediment supply at conditions when wave-induced longshore currents could rapidly expand vertically and laterally. Behind basement elevations and swells water depth rapidly increased and the strong sediment-laden currents rapidly lost their capacity to maintain large quantities of sediment in suspension, which resulted in high rates of sedimentation (see Nielsen and Johannessen, 2009).

Coastal spits may form at all stages of a eustatic sea level cycle (Nielsen and Johannesson, 2008). Nielsen and Johannessen (2009), Leszczyński and Nemec (2015) and Dietrich et al. (2017) interpreted the spit platform as forced regressive shoreface sand wedge. Boyd et al. (1992), Hiroki and Masuda (2000) and Catuneanu (2006) regarded spits as a morphodynamic element of transgressive systems tracts.

The formation of spits associated with bedrock ridges anchored to generally cratonward sides of the small islet/islets as in most present cases - is favoured by a transgression, which flooded the islets and turned such sea floor elevations into sediment-storing littoral shoals. Wave erosion during transgression removed their subaerial part (Dreyer et al., 2005; Nielsen and Johannessen, 2008; Leszczyński and Nemec, 2015). According to the interpretation proposed here, the deposits of FA 1 together with deposits of FA 2-6 represent one depositional sequence marked by erosional unconformities. The deposits of FA 1 (Kühnring Member) might be assigned as "early transgressive systems tract" (Koss et al., 1994; Shanley and McCabe, 1994), especially due to spatially restricted preservation, prevalent vertical accretion and position below "the main" transgressive surface. The upward palaeoenvironmental changes from brackish to upper and lower shoreface deposits indicate a transgression during relative sea level rise. The maximum flooding surface is possibly represented by intensely burrowed beds of FA 5 or even by FA 6 , indicating a relatively lower sediment input during the high relative sea level. Although the sedimentary facies of the Burgschleinitz Formation on the locality Maigen partly differs from the "typical" synchronous deposited lithofacies of the formation, a maximum flooding surface is also apparent in some other outcrops of the Burgschleinitz Formation, like in the type locality in Burgschleinitz Kirchenbruch (e.g., Pervesler et al., 2011).

\section{CONCLUSIONS}

The studied Eggenburgian (Lower Burdigalian) deposits from outcrops next to the village of Maigen, north-west of Eggenburg, exhibit unique sediments with several metres high clinoforms. 
The lithofacies of the studied succession were subdivided into seven facies associations, which correspond to different depositional environments and are assigned to the Lower Miocene lithostratigraphical units in the region. The first facies association is interpreted as brackish sandy muds representing the Kühnring Member. The Burgschleinitz Formation is composed of four facies associations and constitutes a tripartite clinoform zone consisting of bottomset (deposits of lower shoreface), foreset (avalanche deposits) and topset (deposits of upper and lower shoreface). The sixth facies association is formed by the above following Gauderndorf Formation, representing deposits of the lower shoreface in protected areas. The final facies association of the Zogelsdorf Formation is composed of transgressive lag and shoreface deposits, corresponding to a new early Ottnangian transgressive cycle.

Litostratigraphy and facies architecture, palaeocurrent pattern and inferred palaeogeographic setting during deposition suggest that the sands of the Burgschleinitz Formation in the surroundings of Maigen represent coastal spit systems. The approx. W-E trending and SW to SSE prograding spit systems were attached to shoals or islets of the crystalline basement in the shallow marine Eggenburg Bay.

The deposits are composed of 4-5 m thick clinoforms with bottomset, foreset and topset structures, dominantly formed by shoal parallel accretion above fair-weather wave base due to longshore transport. The most impressive parts are up to $3.6 \mathrm{~m}$ thick steeply inclined foresets with cross stratification which are interpreted predominantly as product of avalanche processes. The evidence of sigmoidal as well as oblique brinks and variations in the brink trajectory reveals some modifications in the accommodation space and the existence of individual bar lobes. Reactivation surfaces and mud clasts on foresets indicate variations in current activity, orientation and velocity.

For the formation of the spit deposits relatively stable depositional conditions are assumed, which are characterized by strong unidirectional currents, high sand supply and sufficient accommodation space. Wave-induced longshore currents are supposed to be the dominant and primarily responsible agent for the formation of the studied spit systems. The deposits of the spit systems are interpreted as part of a transgressive systems tract.

The provenance analysis reveals the local crystalline rocks of the Moravian and Moldanubian Superunits (both middle-grade/especially metapelites and high-grade/granulites, gneisses) as principal source of the studied Lower Miocene deposits. Moreover, an input from granites (Thaya Batholith) was also recognized. The primary material was intensely weathered. Especially for the Burgschleinitz Formation redeposition of material from older deposits must also be taken into account. Due to the ongoing transgression, deposits of the Gauderndorf Formation and Zogelsdorf Formation reveal a larger catchment area with input of higher amounts of fresh weathered material from the first cycle of weathering.

Acknowledgements. The second author wants to thank F.F. Steininger and P. Pervesler $(\dagger)$ for many fruitful field campaigns during many years in the Maigen sandpits with numerous students. R.R. also would like to thank the preparators of the Institute of Palaeontology F. Sattler, V. Perlinger and F. Mayer for their multifaceted help and support during these fieldworks as well as the many attending students, doing lot of detailed field recording in all the years. O. Mandic and M. Harzhauser we want to thank for their substantial support in mollusc determination and biofacies interpretation. F. Steininger we additionally thank for fruitful discussions, important information and providing old outcrop photos. E. Lehner we are gratefully for allowing additional investigations in the former Stranzl sandpit. A. Thinschmidt and I. Wimmer-Frey carried out heavy mineral and light mineral investigations many years ago in their early academic years, for which we would like to take this opportunity to thank them once again. The study was gratefully supported by the Geological Survey of Austria. Prof. J. Janočko and two anonymous reviewers are thanked for valuable advices and useful comments on the manuscript.

\section{REFERENCES}

Abel, O., 1898. Studien in den Tertiärbildungen von Eggenburg Beiträge zur Paläontologie und Geologie Österreich-Ungarns 11: $211-226$.

Abel, O., 1904. Die Sirenen der mediterranen Tertiärbildungen Österreichs. Abhandlungen der Geologischen Reichsanstalt, 19: 1-223.

Allard, J., Bertin, X., Chaumillon, E., Pouget, F., 2008. Sand spit rhythmic development: a potential record of wave climate variations? Arcay Spit, western coast of France. Marine Geology, 253: 107-131.

Allen, J.R.L., 1982. Sedimentary Structures: Their Character and Physical Basis. Elsevier, Amsterdam.

Belknap, D.F., Kraft, J.C., 1985. Influence of antecedent geology on stratigraphic preservation potential and evolution of Delaware barrier systems. Marine Geology, 63: 235-262.

Boyd, R., Dalrymple, R.W., Zaitlin, B.A., 1992. Classification of clastic coastal depositional environments. Sedimentary Geology, 80: 139-150.

Breda, A., Mellere, D., Massari, F., 2007. Facies and processes in a Gilbert-delta-filled incised valley (Pliocene of Ventimiglia, NW Italy). Sedimentary Geology, 200: 31-55.

Brzobohatý, R., 1989. Die untermiozäne Otolithenfauna von Maigen bei Eggenburg, Niederösterreich. Annalen des Naturhistorischen Museums in Wien, 90/A: 21-47.
Brzobohatý, R., Schultz, O., 1971. Die Fischfauna der Eggenburger Schichtengruppe. Chronostratigraphie und Neostratotypen, 2: 719-759.

Cattaneo, A., Steel, R.J., 2003. Transgressive deposits: a review of their variability. Earth-Science Reviews, 62: 187-228.

Catuneanu, O., 2006. Principles of Sequence Stratigraphy. Elsevier, Amsterdam.

Clifton, H.E., 1981. Progradational sequences in Miocene shoreline deposits, southeastern Caliente Range, California. Journal of Sedimentary Research, 51: 165-184.

Clifton, H.E., 2006. A reexamination of facies models for clastic shorelines. SEPM Special Publication, 84: 293-338.

Clifton, H.E., Dingler, J.R., 1984. Wave-formed structures and paleoenvironmental reconstruction. Marine Geology, 60: 165-198.

Clifton, H.E., Hunter, R.E., Phillips, R.L., 1971. Depositional structures and processes in the non-barred high-energy nearshore. Journal of Sedimentary Research, 41: 651-670.

Colella, A., De Boer, P.L., Nio, S.D., 1987. Sedimentology of a marine intermontane Pleistocene Gilbert-type fan-delta complex in the Crati Basin, Calabria, Southern Italy. Sedimentology, 34: 721-736.

Collinson, J.D., Mountney, N.P., Thompson, D.B., 2006. Sedimentary Structures. 3rd ed., Terra Publishing, Harpenden. 
Dalrymple, R.W., Mackay, D.A., Ichaso, A.A., Choi, K.S., 2012. Processes, morphodynamics, and facies of tide dominated estuaries. In: Principles of Tidal Sedimentology (eds. R.A. Davis Jr. and R.W. Dalrymple): 79-108. New York, Heidelberg, Springer Science+Business Media BV.

Daxner-Höck, G., 1971. Vertebrata (excl. Pisces) der Eggenburger Schichtengruppe. Chronostratigraphie und Neostratotypen, 2: 761-777.

Demarest, J.M.II., Kraft, J.C., 1987. Stratigraphic record of Quaternary sea levels: implications for more ancient strata. SEPM Special Publication, 41: 223-239.

Depéret, C., 1895. Über die Fauna von miocänen Wirbelthieren aus der ersten Mediterranstufe von Eggenburg. Sitzungsberichte der k. Akademie der Wissenschaften, mathematischnaturwissenschaftliche Classe, I. Abtheilung,104: 395-416.

Dickinson, W.R., 1985. Interpreting provenance relations from detrital modes of sandstone. In: Provenance of Arenites (ed. G.G. Zuffa): 333-361. D. Reidel Publication Co.

Dietrich, P., Ghienne, J.F., Schuster, M., Lajeunesse, P., Nutz, A. Deschamps, R., Roquin, C., Duringer, P., 2017. From outwash to coastal systems in the Portneuf-Forestville deltaic complex (Québec North Shore): Anatomy of a forced regressive deglacial sequence. Sedimentology, 64: 1044-1078.

Dinis, P.A., Huvi, J., Cascalho, J., Garzanti, E., Vermeesch, P., Callapez, P., 2016. Sand-spits systems from Benguela region (SW Angola). An analysis of sediment sources and dispersal from textural and compositional data. Journal of African Earth Sciences, 117: 171-182.

Domning, D.P., Pervesler, P., 2001. The Osteology and Relationships of Metaxytherium krahuletzi Depéret, 1895 (Mammalia: Sirenia). Abhandlungen der Senckenbergischen Naturforschenden Gesellschaft, 553: 1-89.

Dott, R.H., Bourgeois, J., 1982. Hummocky stratification: significance of its variable bedding sequences. GSA Bulletin, 93 663-680.

Dougherty, A.J., FitzGerald, D.M., Buynevich, I.V., 2004. Evidence for storm-dominated early progradation of Castle Neck barrier, Massachusetts, USA. Marine Geology, 210: 123-134.

Dreyer, T., Whitaker, M., Dexter, J., Flesche, H., Larsen, E., 2005 From spit system to tide-dominated delta: integrated reservoir model of the Upper Jurassic Sognefjord Formation on the Troll West Field. In: Petroleum Geology: North-West Europe and Global Perspectives (eds. A.G. Doré and B.A. Vining): 423-448. Proceedings of the 6th Petroleum Geology Conference, Geological Society, London.

Droser, M.L., Bottjer, D.J., 1986. A semiquantitative field classification of ichnofabric. Journal of Sedimentary Research, 56: 558-559.

Dumas, S., Arnott, R.W.C., 2006. Origin of hummocky and swaley cross-stratification - The controlling influence of unidirectional current strength and aggradation rate. Geology, 34: 1073-1076.

Dumas, S., Arnott, R.W.C., Southard, J.B., 2005. Experiments on oscillatory-flow and combined-flow bed forms: implications for interpreting parts of the shallow marine sedimentary record. Journal of Sedimentary Research, 75: 501-513.

Ehrenberg, K., 1938. Bauten von Decapoden (Calianassa sp.) aus dem Miozän (Burdigal) von Burgschleinitz bei Eggenburg im Gau Nieder-Donau (Niederösterreich). Paläontologische Zeitschrift, 20: 273-275.

Ehrenberg, K., 1944. Ergänzende Bemerkungen zu den seinerzeit aus dem Miozän von Burgschleinitz beschrieben Gangkernen und Bauten dekapoder Krebse. Paläontologische Zeitschrift, 23: $354-359$.

Fitzgerald, D.M., Penland, S., Nummedal, D., 1984. Control of barrier island shape by inlet sediment bypassing: East Frisian Islands, West Germany. Marine Geology, 60: 355-376.

Folk, R.L., 1968. Petrology of Sedimentary Rocks. Hemphill's Bookstore, Austin, Texas.

Friedman, G.M., 1962. On sorting, sorting coefficients, and the lognormality of the grain-size distribution of sandstones. The Journal of Geology, 70: 737-753.
Fruergaard, M., Andersen, T.J., Johannessen, P.N., Nielsen, L.H., Pejrup, M., 2013. Major coastal impact induced by a 1000-year storm event. Scientific Report, 3: 1-7

Fruergaard, M., Andersen, T.J., Nielsen, L.H., Johannessen, P.N., Aagaard, T., Pejrup, M., 2015a. High-resolution reconstruction of a coastal barrier system: impact of Holocene sea-level change. Sedimentology, 62: 928-969.

Fruergaard, M., Møller, I., Johannessen, P.N., Nielsen, L.H., Andersen, T.J., Nielsen, L., Sander, L., Pejrup, M., 2015b. Stratigraphy, evolution, and controls of a Holocene transgressive-regressive barrier island under changing sea level: Danish North Sea coast. Journal of Sedimentary Research, 85: 820-844.

Fruergaard, M., Johannessen, P.N., Nielsen, L.H., Nielsen, L., Møller, I., Andersen, T.J., Piasecki, S., Pejrup, M., 2018. Sedimentary architecture and depositional controls of a Holocene wave-dominated barrier-island system. Sedimentology, 65: $1170-1212$.

Fruergaard, M., Tessier, B., Poirier, C., Mouaz, D., Weill, P., Noel, S., 2020. Depositional controls on a hypertidal barrier-spit system architecture and evolution, Pointe du Banc spit, north-western France. Sedimentology, 67: 502-533.

Füchtbauer, H., 1959. Zur Nomenklatur der Sedimentgesteine. Erdöl und Kohle, 12: 605-613.

Girty, G.H., Marsh, J., Meltzner, A., McConnell, J.R., Nygren, D. Nygren, J., Prince, G.M., Randall, K., Johnson, D., Heitman B., Nielsen, J., 2003. assessing changes in elemental mass as a result of chemical weathering of granodiorite in a Mediterranean (hot summer) climate. Journal of Sedimentary Research, 73: 434-443.

Grunert, P., Soliman, A., Harzhauser, M., Müllegger, S., Piller, W., Roetzel, R., Rögl, F., 2010. Upwelling conditions in the Early Miocene Central Paratethys Sea. Geologica Carpathica, 61: 129-145.

Hampson, G.J., 2000. Discontinuity surfaces, clinoforms, and facies architecture in a wave-dominated, shoreface-shelf parasequence. Journal of Sedimentary Research, 70: 325-340.

Hampson, G.J., Storms, J.E.A., 2003. Geomorphological and sequence stratigraphic variability in wave-dominated, shoreface-shelf parasequences. Sedimentology, 50: 667-701.

Hart, B.S., Plint, A.G., 1995. Gravelly shoreface and beachface deposits. IAS Special Publication, 22: 75-99.

Hine, A.C., 1979. Mechanisms of berm development and resulting beach growth along a barrier spit complex. Sedimentology, 26: 333.

Hiroki, Y., Masuda, F., 2000. Gravelly spit deposits in a transgressive systems tract: the Pleistocene Higashikanbe Gravel, central Japan. Sedimentology, 47: 135-149.

Hohenegger, J., Pervesler, P., 1985. Orientation of crustacean burrows. Lethaia, 18: 323-339.

Hubert, J.F., 1962. A zircon-tourmaline-rutile maturity index and the interdependence of the composition of heavy mineral assemblages with the gross composition and texture of sandstones. Journal of Sedimentary Research, 32: 440-450.

Hunter, R.E., Clifton, H.E., Phillips, R.L., 1979. Depositional processes, sedimentary structures, and predicted vertical sequences in barred nearshore systems, southern Oregon coast. Journal of Sedimentary Research, 49: 711-726.

Hwang, I.G., Heller, P.L., 2002. Anatomy of a transgressive lag: Panther Tongue Sandstone, Star Point Formation, central Utah. Sedimentology, 49: 977-999.

Johnson, H.D., Baldwin, C.T., 1996. Shallow siliciclastic seas. In: Sedimentary Environments: Processes, Facies and Stratigraphy (ed. H.G. Reading): 232-280. Blackwell Science Ltd., Oxford, U.K..

Jopling, A.V., 1965. Hydraulic factors controlling the shape of laminae in laboratory deltas. Journal of Sedimentary Research, 35: 777-791.

Komar, P.D., Miller, M.C., 1975. The initiation of oscillatory ripple marks and the development of plane-bed at high shear stresses under waves. Journal of Sedimentary Research, 45: 697-703. 
Koss, J.E., Ethridge, F.G., Schumm, S.A., 1994. An experimenta study of the effect of base-level change on fluvial, coastal and shelf systems. Journal of Sedimentary Research, 64: 90-98.

Lang, J., Winsemann, J., 2013. Lateral and vertical facies relationships of bedforms deposited by aggrading supercritical flows: From cyclic steps to humpback dunes. Sedimentary Geology 296: $36-54$

Leszczyński, S., Nemec, W., 2015. Dynamic stratigraphy of composite peripheral unconformity in a foredeep basin. Sedimentology, 62: 645-680.

Lindhorst, S., Betzler, C., Hass, H.C., 2008. The sedimentary architecture of a Holocene barrier spit (Sylt, German Bight) swash-bar accretion and storm erosion. Sedimentary Geology, 206: $1-16$

Lindhorst, S., Furstenau, J., Hass, H.C., Betzler, C., 2010 Anatomy and sedimentary model of a hooked spit (Sylt, southern North Sea). Sedimentology, 57: 935-955.

Longhitano, S.G., 2008. Sedimentary facies and sequence stratigraphy of coarse-grained Gilbert-type deltas within the Pliocene thrust-top Potenza Basin (Southern Apennines, Italy) Sedimentary Geology, 210: 87-110.

Mäkinen, J., Räsänen, M., 2003. Early Holocene regressive spit-platform and nearshore sedimentation on a glaciofluvial complex during the Yoldia Sea and the Ancylus Lake phases of the Baltic Basin, SW Finland. Sedimentary Geology, 158 25-56.

Mandic, O., Reisinger, Ch., 1992. Bericht über die Profilaufnahme der Faziesabfolgen des Untermiozäns (Eggenburgium) von Maigen im Raum Eggenburg/NÖ. Spezielle Paläontologische Übungen II: Geländepraktikum 1992. Unpublished Report, Institute of Palaeontology, Univ. Wien, 1-12, Archive Geological Survey Vienna, A-18718-R1, Wien.

Mandic, O., Steininger, F.F., 2003. Computer-based mollusc stratigraphy - a case study from the Eggenburgian (Lower Miocene) type region (NE Austria). Palaeogeography, Palaeoclimatology, Palaeoecology, 197: 263-291.

Massari, F., Parea, G.C., 1988. Progradational gravel beach sequences in a moderate- to high-energy, microtidal marine environment. Sedimentology, 35: 881-913.

Massari, F., Parea, G.C., 1990. Wave-dominated Gilbert-type gravel deltas in the hinterland of the Gulf of Taranto. IAS Special Publication, 10: 311-331.

Mein, P., 1989. Die Kleinsäugerfauna des Untermiozäns (Eggenburgien) von Maigen, Niederösterreich. Annalen des Naturhistorischen Museums in Wien, 90/A: 49-58.

Meistrell, F.J., 1972. The spit-platform concept: laboratory observation of spit development. In: Spits and Bars (ed. M.L. Schwartz) 225-283. Dowden, Hutchinson and Ross, Stroudsberg, PA

Monge-Ganuzas, M., Evans, G., Cearreta, A., 2015. Sand-spit accumulations at the mouths of the eastern Cantabrian estuaries: The example of the Oka estuary (Urdaibai Biosphere Reserve) Quaternary International, 364: 206-216.

Morton, A.C., Hallsworth, C.R., 1994. Identifying provenance-specific features of detrital heavy mineral assemblages in sandstones. Sedimentary Geology, 90: 241-256.

Morton, A.C., Hallsworth, C.R., 1999. Processes controlling the composition of heavy mineral assemblages in sandstones. Sedimentary Geology, 124: 3-29.

Morton, R.A., Sallenger, A.H., 2003. Morphological impacts of extreme storms on sandy beaches and barriers. Journal of Coastal Research, 19: 560-573.

Müller, G., 1961. Das Sand-Silt-Ton Verhältnis in rezenten marinen Sedimenten. Neues Jahrbuch für Mineralogie, Monatshefte, (1961): 148-163

Nalin, R., Massari, F., 2009. Facies and stratigraphic anatomy of a temperate carbonate sequence (Capo Colonna terrace, Late Pleistocene, southern Italy). Journal of Sedimentary Research, 79: 210-225.

Nebelsick, J.H., 1989a. Die fazielle Gliederung der Zogelsdorf Formation (Untermiozän: Eggenburgian) in Niederösterreich anhand mikrofazieller Untersuchungsmethoden. Diplomarbeit
Formal- und Naturwissenschaftliche Fakultät der Universität Wien.

Nebelsick, J.H., 1989b. Temperate water carbonate facies of the Early Miocene Paratethys (Zogelsdorf Formation, Lower Austria). Facies, 21: 11-40.

Nehyba, S., 2018. Lower Badenian coarse-grained Gilbert deltas in the southern margin of the Western Carpathian Foredeep basin. Geologica Carpathica, 69: 89-113.

Nehyba, S., Roetzel, R., 2010. Fluvial deposits of the St. Marein-Freischling Formation - insights into initial depositional processes on the distal external margin of the AlpineCarpathian Foredeep in Lower Austria. Austrian Journal of Earth Sciences, 103: 50-80.

Nemec, W., 1990. Aspects of sediment movement on steep delta slopes. IAS Special Publication, 10: 29-73.

Neumayr, M., 1888. Hyopotamusreste von Eggenburg. Verhandlungen der Geologischen Reichsanstalt, 1888: 283-285.

Nielsen, L.H., Johannessen, P.N., 2008. Are some isolated shelf sandstone ridges in the Cretaceous Western Interior Seaway transgressed, detached spit systems? SEPM Special Publication, 90: 333-354.

Nielsen, L.H., Johannessen, P.N., 2009. Facies architecture and depositional processes of the Holocene-Recent accretionary forced regressive Skagen spit System, Denmark. Sedimentology, 56: 935-968.

Nielsen, L.H., Johannessen, P.N., Surlyk, F., 1988. A Late Pleistocene coarse-grained spitplatform sequence in Northern Jylland Denmark. Sedimentology, 35: 915-937.

Nummedal, D., Swift, D.J.P., 1987. Transgressive stratigraphy at sequence-bounding unconformities: Some principles derived from Holocene and Cretaceous examples. SEPM Special Publication, 41: 241-260.

Okada, H., 1971. Classification of sandstone: analysis and proposal. The Journal of Geology, 79: 509-525.

Oliver, T.S.N., Donaldson, P., Sharples, C., Roach, M., Woodroffe, C.D., 2017. Punctuated progradation of the Seven Mile Beach Holocene barrier system, southeastern Tasmania. Marine Geology, 386: 76-87.

Otvos, E.G., 2000. Beach ridges definitions and significance. Geomorphology, 32: 83-108.

Patruno, S., Hampson, G.J., Jackson, Ch.A.L., Dreyer, T., 2015. Clinoform geometry, geomorphology, facies character and stratigraphic architecture of a sand-rich subaqueous delta: Jurassic Sognefjord Formation, offshore Norway. Sedimentology, 62: 350-388.

Pellegrini, C., Patruno, S., Helland-Hansen, W., Steel, R.J., Trincardi, F., 2020. Clinoforms and clinothems: fundamental elements of basin infill. Basin Research, 32: 187-205.

Penland, S., Boyd, R., Suter, J.R., 1988. Transgressive depositional systems of the Mississippi delta plain: a model for barrier shoreline and shelf sand development. Journal of Sedimentary Research, 58: 932-949.

Pervesler, P., Roetzel, R., Steininger, F.F., 1995. Taphonomie der Sirenen in den marinen Flachwasserablagerungen (Burgschleinitz-Formation, Eggenburgium, Untermiozän) der Gemeindesandgrube Kühnring (Niederösterreich). Jahrbuch der Geologischen Bundesanstalt, 138: 89-121.

Pervesler, P., Roetzel, R., Uchman, A., 2011. Ichnology of shallow sublittoral siliciclastics of the Burgschleinitz Formation (Lower Miocene, Eggenburgian) in the Alpine-Carpathian Foredeep (NE Austria). Austrian Journal of Earth Sciences, 104: 81-96.

Petersen, D., Deigaard, R., Fredsøe, J., 2008. Modelling the morphology of sandy spits. Costal Engineering, 55: 671-684.

Pettijohn, F.J., Potter, P.E., Siever, R., 1987. Sand and Sandstone. 2nd ed., Springer, New York.

Piller, W.E., Harzhauser, M., Mandic, O., 2007. Miocene Central Paratethys stratigraphy - current status and further directions. Stratigraphy, 4: 151-168.

Rasmussen, E.S., Dybkjær, K., 2005. Sequence stratigraphy of the Upper Oligocene-Lower Miocene of eastern Jylland, Denmark: role of structural relief and variable sediment supply in controlling sequence development. Sedimentology, 52: 25-63. 
Reading, H., Collinson, J.D., 1996. Clastic coasts. In: Sedimentary Environments: Processes, Facies and Stratigraphy (ed. $\mathrm{H}$. Reading): 155-231. Blackwell Science, Oxford.

Reineck, H.E., Singh, I.B., 1980. Depositional Sedimentary Environments. 2nd ed., Springer, Berlin-Heidelberg-New York.

Reitner, H., Malecki, G., Roetzel, R., 2005. SedPacWin - SedpacMac - Characterization of Sediments by Grainsize Analysis. Geophysical Research Abstracts, 7, EGU General Assembly Vienna 2005, SRef-ID: 1607-7962/gra/EGU05-A-04297.

Riggs, S.R., Cleary, W.J., Snyder, S.W., 1995. Influence of inherited geologic framework on barrier shoreface morphology and dynamics. Marine Geology, 126: 213-234.

Roetzel, R., 1990. Die Burgschleinitz Formation (Eggenburgien, Untermiozän) im Raum Eggenburg (Niederösterreich). Beispie einer wellendominierten marinen Seichtwasserfazies. Sediment 90, 5. Sedimentologen-Treffen am 6-7.Juni 1990 Bonn, Vorträge, Geologisches Institut Universität Bonn.

Roetzel, R., Mandic, O., Steininger, F.F., 1999. Lithostratigraphie und Chronostratigraphie der tertiären Sedimente im westlichen Weinviertel und angrenzenden Waldviertel. In: Arbeitstagung Geologische Bundesanstalt 1999, Geologische Karten ÖK 9 Retz und ÖK 22 Hollabrunn, Geogenes Naturraumpotential der Bezirke Horn und Hollabrunn (ed. R. Roetzel): 38-54

Roetzel, R., Ćorić, S., Galović, I., Rögl, F., 2006. Early Miocene (Ottnangian) coastal upwelling conditions along the southeastern scarp of the Bohemian Massif (Parisdorf, Lower Austria, Central Paratethys). Beiträge zur Paläontologie, 30: 387-413.

Roštínský, P., Roetzel, R., 2005. Exhumed Cenozoic landforms on the SE flank of the Bohemian Massif in the Czech Republic and Austria. Zeitschrift für Geomorphologie, NF, 49: 23-45.

Schaffer, F.X., 1910. Die Bivalven der Miocänbildungen von Eggenburg. Abhandlungen der Geologischen Reichsanstalt, 22: $5-112$.

Schaffer, F.X., 1912. Die Gastropoden der Miocänbildungen von Eggenburg. Mit einem Anhang über Cephalopoden, Crinoiden, Echiniden und Brachiopoden. Abhandlungen der Geologischen Reichsanstalt, 22: 127-193.

Schaffer, F.X., 1914. Die tertiären und diluvialen Bildungen Abhandlungen der Geologischen Reichsanstalt, 22: 1-124.

Schaffer, F.X., 1925. Die Säugetiere und Reptilien des Miocäns von Eggenburg. Abhandlungen der Geologischen Bundesanstalt, 22: 44 .

Schauer, M., Schattleitner, M., 1982. Zur Stratigraphie und Fossilführung der Eggenburger Schichtgruppe in der Sandgrube Dipl. Ing. G. Wagerer SSO Maigen bei Eggenburg (Niederösterreich). Spezielle Paläontologische Übungen II: Geländepraktikum 1982, Unpublished Report, Institute of Palaeontology, Univ. Wien, 1-38, Archive Geological Survey Vienna, A-18728-R, Wien.

Shanley, K.W., McCabe, P.J., 1994. Perspectives on the sequence stratigraphy of continental strata. AAPG Bulletin, 78: 544-568.

Steininger, F., 1971. Holostratotypus und Faziostratotypen der Eggenburger Schichtengruppe im Raume von Eggenburg in Niederösterreich (Österreich). Chronostratigraphie und Neostratotypen, 2: 104-167.

Steininger, F., 1977. Haltepunkt 15: Maigen. Arbeitstagung der Geologischen Bundesanstalt 1977. Waldviertel. Geologische Bundesanstalt, Wien. 59-61.
Steininger, F., 1983. Haltepunkt 5: Maigen (Sandgrube Stranzl) Zur Geologie des Kristallins und Tertiärs der weiteren Umgebung von Eggenburg, Exkursionsführer Österreichische Geologische Gesellschaft, 1: 40-41.

Steininger, F.F., 1999. The Continental European Miocene. Chronostratigraphy, Geochronology and Biochronology of the Miocene "European Land Mammal Mega-Zones" (ELMMZ) and the Miocene "Mammal-Zones (MN-Zones)". In: The Miocene Land Mammals of Europe (eds. G. Rössner and K. Heissig): 9-24. F. Pfeil, München.

Steininger, F.F., Roetzel, R., Pervesler, P., Nebelsick, J., Jenke, Y., 1991a. Haltepunkt 1 Maigen - Sandgrube Stranzl. In: Geologie am Ostrand der Böhmischen Masse in Niederösterreich. Schwerpunkt: Blatt 21 Horn (ed. R. Roetzel): 161-165. Arbeitstagung der Geologischen Bundesanstalt.

Steininger, F.F., Roetzel, R., Pervesler, P., Nebelsick, J., Jenke, Y., 1991b. F/8: Maigen, Sandgrube Stranzl. In: Exkursionen im Tertiär Österreichs - Molassezone, Waschbergzone, Korneuburger Becken, Wiener Becken, Eisenstädter Becken (eds. R. Roetzel and D. Nagel): 104-111. Österreichische Paläontologische Gesellschaft, Wien.

Steininger, F.F., Berggren, W.A., Kent, D.V., Bernor, R.L., Sen, S. Agusti, J., 1996. Circum-Mediterranean Neogene (Miocene and Pliocene) Marine - Continental Chronologic Correlations of European Mammal Units and Zones. In: Later Neogene European Biotic Evolution and Stratigraphic Correlation (eds R.L. Bernor, V. Fahlbusch and S. Rietschel): 7-46. Columbia University Press, New York.

Suess, E., 1866. Untersuchungen über den Charakter der österreichischen Tertiärablagerungen. I. Über die Gliederung der tertiären Bildungen zwischen dem Mannhart, der Donau und dem äusseren Saume des Hochgebirges. Sitzungsberichte der Akademie der Wissenschaften, mathemathisch-naturwissenschaftliche Klasse, 54: 87-149.

Tamura, T., 2012. Beach ridges and prograded beach deposits as paleoenvironmental records. Earth-Science Reviews, 114: 279-297.

Toula, F., Kail, J.A., 1885. Über einen Krokodil-Schädel aus den Tertiärablagerungen von Eggenburg in Niederösterreich. Eine Paläontologische Studie. Denkschriften der Akademie der Wissenschaften, mathematisch-naturwissenschaftliche Klasse, 50: 299-355.

Van Heteren, S., Van De Plassche, O., 1997. Influence of relative sea-level change and tidal-inlet development on barrier-spit stratigraphy, Sandy Neck, Massachusetts. Journal of Sedimentary Research, 67: 350-363

Walker, R.G., James, N.P., 1992. Facies Models: Response to Sea Level Changes. Geological Association of Canada, St. John's: 1-409.

Zecchin, M., Civile, D., Caffau, M., Roda, C., 2009. Facies and cycle architecture of a Pleistocene marine terrace (Crotone, southern Italy): a sedimentary response to late Quaternary, high-frequency glacio-eustatic changes. Sedimentary Geology, 216: 138-157.

Zecchin, M., Caffau, M., Civile, D., Roda, C., 2010. Anatomy of a late Pleistocene clinoformal sedimentary body (Le Castella, Calabria, southern Italy): a case of prograding spit system? Sedimentary Geology, 223: 291-309. 